\title{
Nickel-Catalyzed Kumada Vinylation of Enol Phosphates: A Comparative Mechanistic Study
}

\author{
Philippe-Alexandre Poisson, Gaël Tran, Céline Besnard and Clément Mazet* \\ Department of Organic Chemistry, University of Geneva \\ 30 Quai Ernest Ansermet, 1211 Geneva, Switzerland \\ clement.mazet@unige.ch
}

\section{Table of contents}

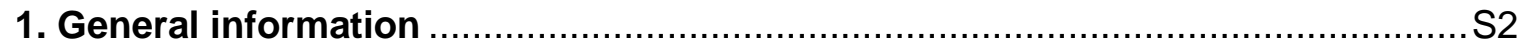

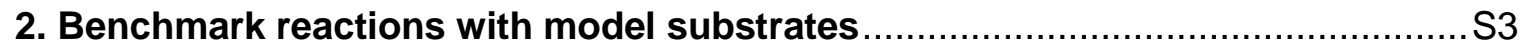

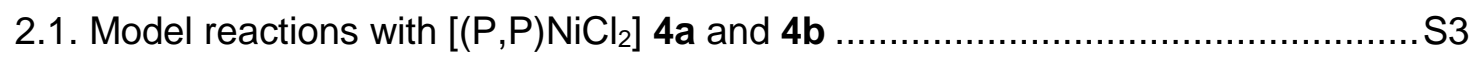

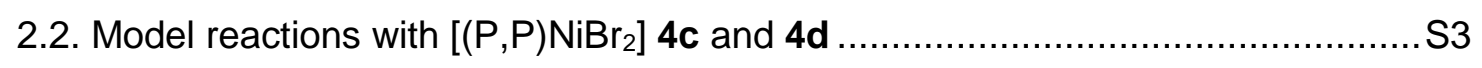

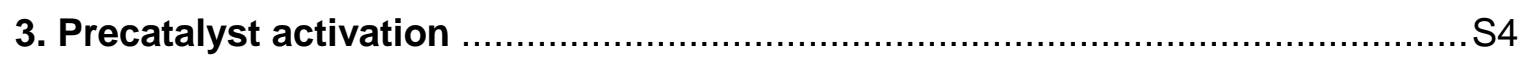

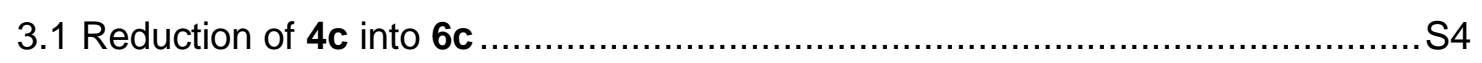

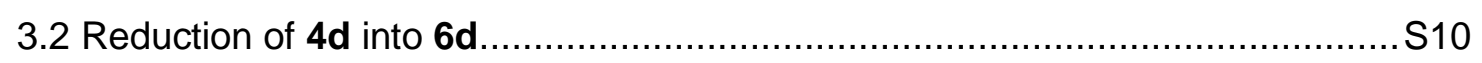

$3.3 \mathrm{Ni}$-catalyzed vinylation of $1 \mathrm{a}$ with in situ generated $\mathrm{Ni}(0) \mathbf{6 c}$ or $\mathbf{6 d} \ldots \ldots \ldots \ldots \ldots . . . . . . . . . .313$

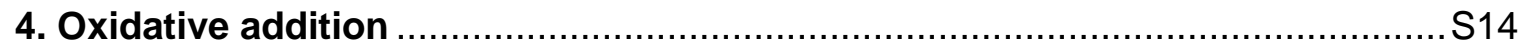

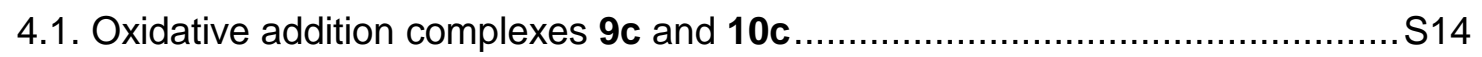

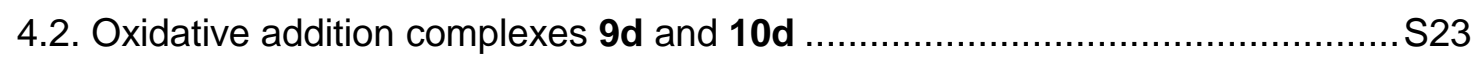

5. Transmetalation/Reductive elimination .................................................... 32

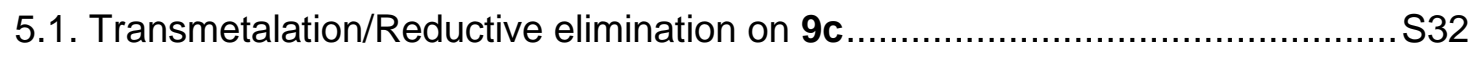

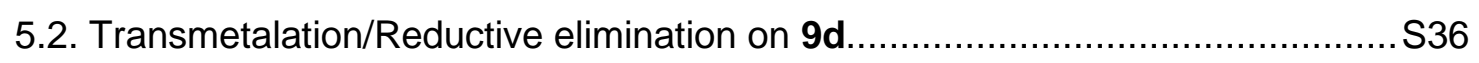

6. NMR monitoring of the catalytic reaction ................................................... 38

7. Indirect evidence for the formation of vinyl nickel intermediates.....................S41

8. Radical clock and radical trapping experiments .......................................... 445

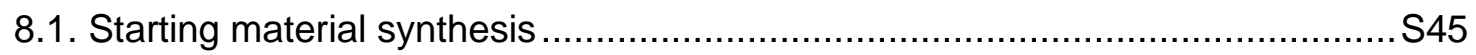

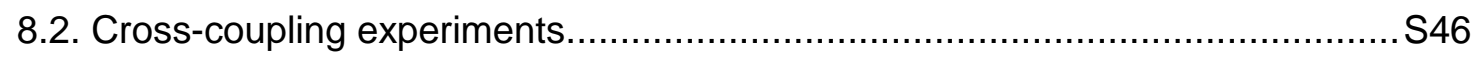

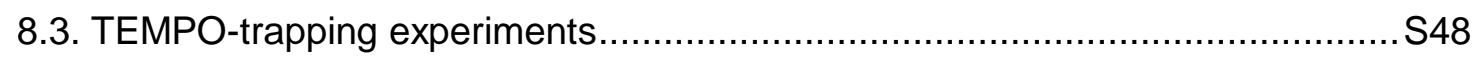

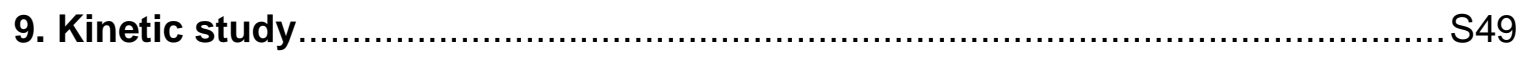

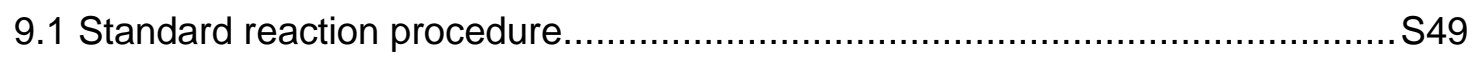

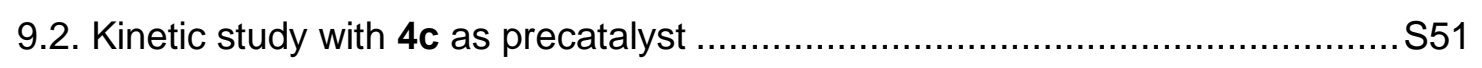

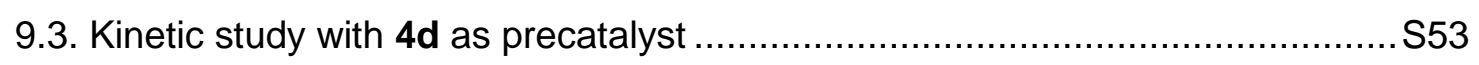

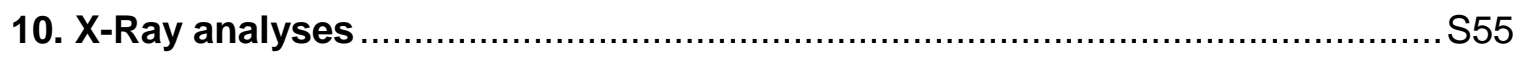

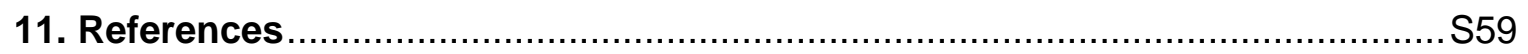

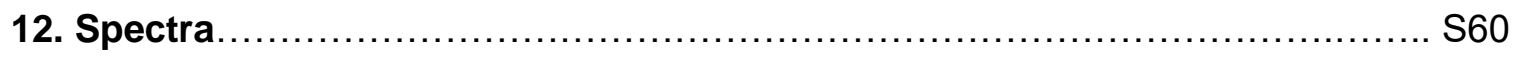




\section{General information}

All reactions were carried out under an inert atmosphere of nitrogen using either two-manifold vacuum/inert nitrogen lines or a M.Braun glove-box. THF, $\mathrm{Et}_{2} \mathrm{O} \mathrm{CH}_{2} \mathrm{Cl}_{2}$, toluene, and pentane were degassed by argon bubbling, dried over activated alumina columns. NMR spectra were recorded on AMX-300, AMX-400 and AMX-500 MHz Bruker Avance spectrometers at $298 \mathrm{~K}$ (unless otherwise specified). ${ }^{1} \mathrm{H}$ and ${ }^{13} \mathrm{C}\left\{{ }^{1} \mathrm{H}\right\}$ NMR chemical shifts are given in ppm relative to $\mathrm{SiMe}_{4}$, with the solvent resonance used as internal reference. ${ }^{1} \mathrm{H}$ NMR spectra were referenced to $\mathrm{CDCl}_{3}(7.26 \mathrm{ppm})$ or THF- $d_{8}(3.58 \mathrm{ppm})$ and ${ }^{13} \mathrm{C}\left\{{ }^{1} \mathrm{H}\right\}$ NMR spectra were referenced to $\mathrm{CDCl}_{3}(77.16 \mathrm{ppm})$ or THF- $d_{8}(67.21 \mathrm{ppm})$. Infrared spectra were obtained on a Perkin-Elmer 1650 FT-IR spectrometer using neat sample on a diamond ATR Golden Gate sampler. GC-MS analyses were performed on GC - HP 6890, column Agilent - HP1 (30 m ID $0.32 \mathrm{~mm}$, Film $0.25 \mu \mathrm{m}$ ) coupled with MS - HP 5973. Thin layer chromatography (TLC) was performed on plates of silica precoated with $0.25 \mathrm{~mm}$ Kieselgel $60 \mathrm{~F}_{254}$ from Merck. Flash chromatography was performed using silica gel SiliaFlash® P60 (230-400 mesh) from Silicycle. Commercially available reagents and ligands were purchased from Aldrich, Acros or Strem and used without purification unless otherwise noted. Liquid reagents were transferred with stainless steel syringes or cannula. Commercially available Grignard solutions in THF either from Acros (AcroSeal $\AA^{\circledR}$ ) or Aldrich (Sure/Seal $\circledast$ ) were titrated prior to use following a literature procedure. ${ }^{1}$ Nickel precatalysts, as well as ligands were stored and weighted inside a M.Braun glove-box. The complexes $\left[(\mathrm{dppe}) \mathrm{NiBr}_{2}\right]^{2}$ and $\left[(\mathrm{dmpe}) \mathrm{NiBr}_{2}\right]^{3}$ were prepared following a literature procedure (dppe =1,2-bis(diphenylphosphino)ethane), (dmpe = 1,2bis(dimethylphosphino)ethane), (DME = dimethylethoxyethane). 1-(2-(3-methylbut-2-en-1yl)phenyl)ethanone was prepared following a literature procedure. ${ }^{4}$ TEMPO (TEMPO = 2,2,6,6-tetramethylpiperidin-1-yl)oxyl) was purified by sublimation prior to use. 


\section{Benchmark reactions with model substrates}

\subsection{Model reactions with $\left[(P, P) N_{i C l}\right] 4 a$ and $4 b$}<smiles>[R]C(=C)O[Po](=O)OCC</smiles>

1<smiles>C=CC(=O)OCC(=O)O</smiles>

2a

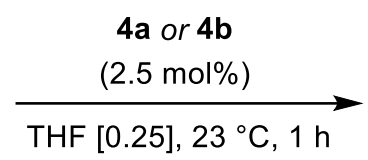

3aa

4a: $84 \%$

4b: $78 \%$<smiles>[R]C(=C)C=C</smiles>

3

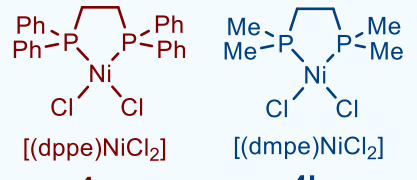

4a

$4 b$<smiles>C=CC(=C)c1ccc(-c2ccccc2)cc1</smiles>

$3 a b$

4a: $84 \%$

4b: $74 \%$

$3 a c$

4a: $84 \%$

4b: $76 \%$

Figure S1.

The procedure was adapted from a previous report 5 . In a $\mathrm{N}_{2}$-filled glovebox, the precatalyst $\mathbf{4 a}$ or $\mathbf{4 b}(6.25 \mu \mathrm{mol}, 2.5 \mathrm{~mol} \%)$ and the corresponding enol phosphate (0.25 mmol, 1.0 equiv) were charged in a $5 \mathrm{~mL}$ Schlenk and dissolved in THF (final concentration $0.25 \mathrm{M}$ ). The Schlenk was sealed, taken out of the glovebox, cooled to $0{ }^{\circ} \mathrm{C}$, and a solution of vinyl magnesium bromide $2 \mathrm{a}$ in THF was added dropwise $(0.26 \mathrm{mmol}, 1.05$ equiv). The ice bath was removed and the reaction mixture was stirred for 1 hour at room temperature. The reaction was quenched by addition of $5.0 \mathrm{~mL}$ of a saturated solution of ammonium chloride at $0{ }^{\circ} \mathrm{C}$ and extracted with diethyl ether $(3 \times 25 \mathrm{~mL})$. The organic layers were combined, dried over sodium sulfate, filtered and the solvent removed under vacuum. The crude residue was purified by flash column chromatography with pentane as eluent to afford the pure diene 3 .

\subsection{Model reactions with $\left[(P, P) N_{i B r}\right] 4 c$ and $4 d$}<smiles>[R]C(=C)O[R](=O)O[Na]</smiles>

1

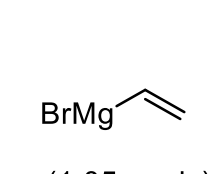

(1.05 equiv)

$2 \mathrm{a}$

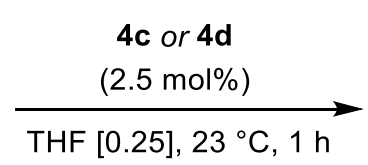

$\operatorname{THF}[0.25], 23^{\circ} \mathrm{C}, 1 \mathrm{~h}$<smiles>C=CC(=C)c1ccc(CC(C)C)cc1</smiles>

4c: $93 \%$

4d: $80 \%$

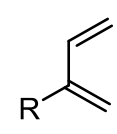

3

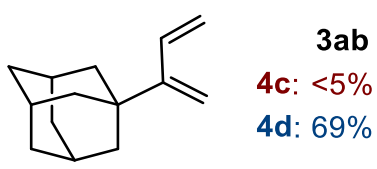

Figure S2. 
In a $\mathrm{N}_{2}$-filled glovebox, the precatalyst $\mathbf{4 c}$ or $\mathbf{4 d}(6.25 \mu \mathrm{mol}, 2.5 \mathrm{~mol} \%)$ and enol phosphate (0.25 mmol, 1.0 equiv) were charged in a $2 \mathrm{~mL}$ Schlenk and dissolved in THF (final concentration: $0.25 \mathrm{M}$ ). The Schlenk was sealed, taken out of the glovebox, cooled to $0{ }^{\circ} \mathrm{C}$, and a solution of vinyl magnesium bromide $2 \mathrm{a}$ in THF was added dropwise $(0.26 \mathrm{mmol}, 1.05$ equiv). The ice bath was removed and the reaction mixture was stirred for 1 hour at room temperature. The reaction was quenched by addition of $5.0 \mathrm{~mL}$ of a saturated solution of ammonium chloride at $0^{\circ} \mathrm{C}$ and extracted with diethyl ether $(3 \times 25 \mathrm{~mL})$. The combined organic layers were dried over sodium sulfate, filtered and the solvent removed under vacuum affording the crude residue. An internal standard was added ( $p$-methylanisole) and the conversions were determined by ${ }^{1} \mathrm{H}$ NMR.

\section{Precatalyst activation}

\subsection{Reduction of $4 c$ into $6 c$}

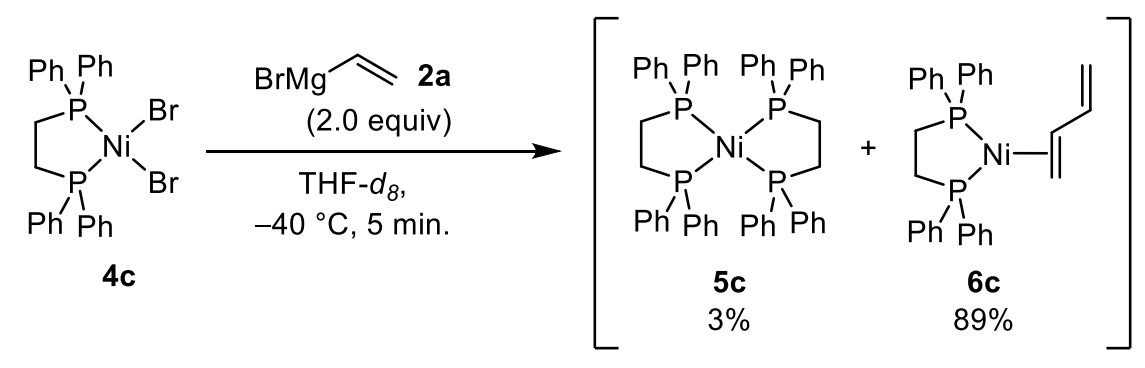

Figure S3.

Determination of the conversion. In a $\mathrm{N}_{2}$-filled glovebox, [(dppe) $\left.\mathrm{NiBr}_{2}\right] \mathbf{4 c}(0.01 \mathrm{mmol}, 6.2$ $\mathrm{mg}, 1.0$ equiv) was charged in a $5 \mathrm{~mL}$ Schlenk, followed by a $44.8 \mathrm{mM}$ stock solution of $1,3-$ di-tert-butyl-2-methoxy-5-methylbenzene in THF- $d_{8}(2.24 \mu \mathrm{mol}, 50 \mu \mathrm{L})$ and THF- $d_{8}(0.5 \mathrm{~mL}$, $0.04 \mathrm{M})$. The Schlenk was sealed, taken out of the glovebox, cooled to $-40{ }^{\circ} \mathrm{C}$, and a $0.80 \mathrm{M}$ solution of vinyl magnesium bromide $2 \mathrm{a}$ in THF was added ( $0.02 \mathrm{mmol}, 25 \mu \mathrm{L}, 2.0$ equiv). The reaction mixture was stirred at $-40^{\circ} \mathrm{C}$ for 5 minutes, then frozen in liquid nitrogen. The Schlenk was quickly introduced in a $\mathrm{N}_{2}$-filled glovebox, and the content of the tube was transferred in a J-Young NMR tube, which was immediately analyzed by NMR at room temperature. ${ }^{1} \mathrm{H}$ NMR indicated a $89 \%$ conversion into the $[(\mathrm{dppe}) \mathrm{Ni}(\mathbf{3 g})] \mathbf{6 c}$ complex, along with $3 \%$ of $\left[(\mathrm{dppe})_{2} \mathrm{Ni}\right]$ $5 c$. 


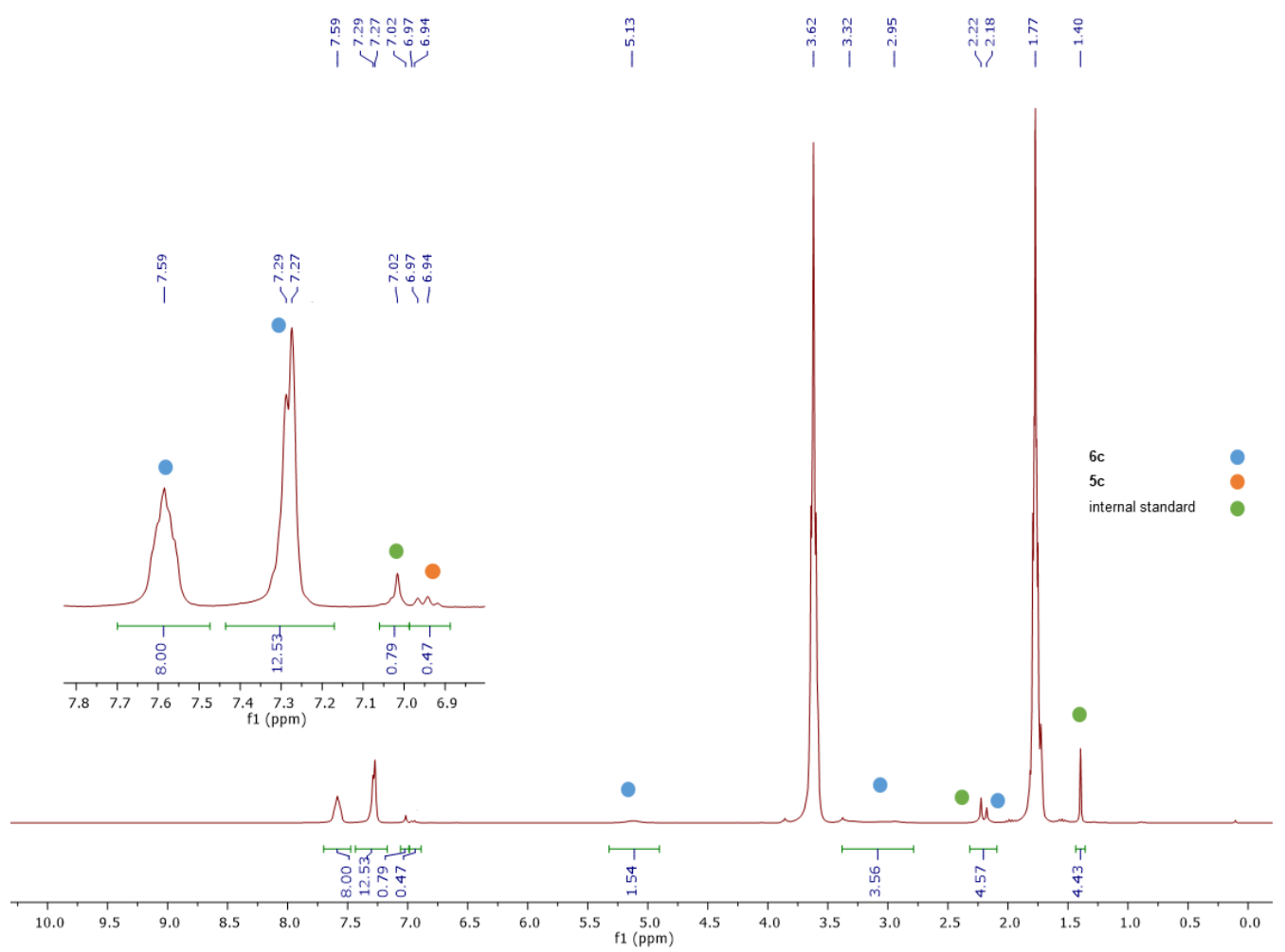

Figure S4. ${ }^{1} \mathrm{H}$ NMR (400 MHz, THF- $\left.d_{8}, 298 \mathrm{~K}\right)$ spectrum of $4 \mathrm{c}$ into $6 \mathrm{c}$ reduction reaction.
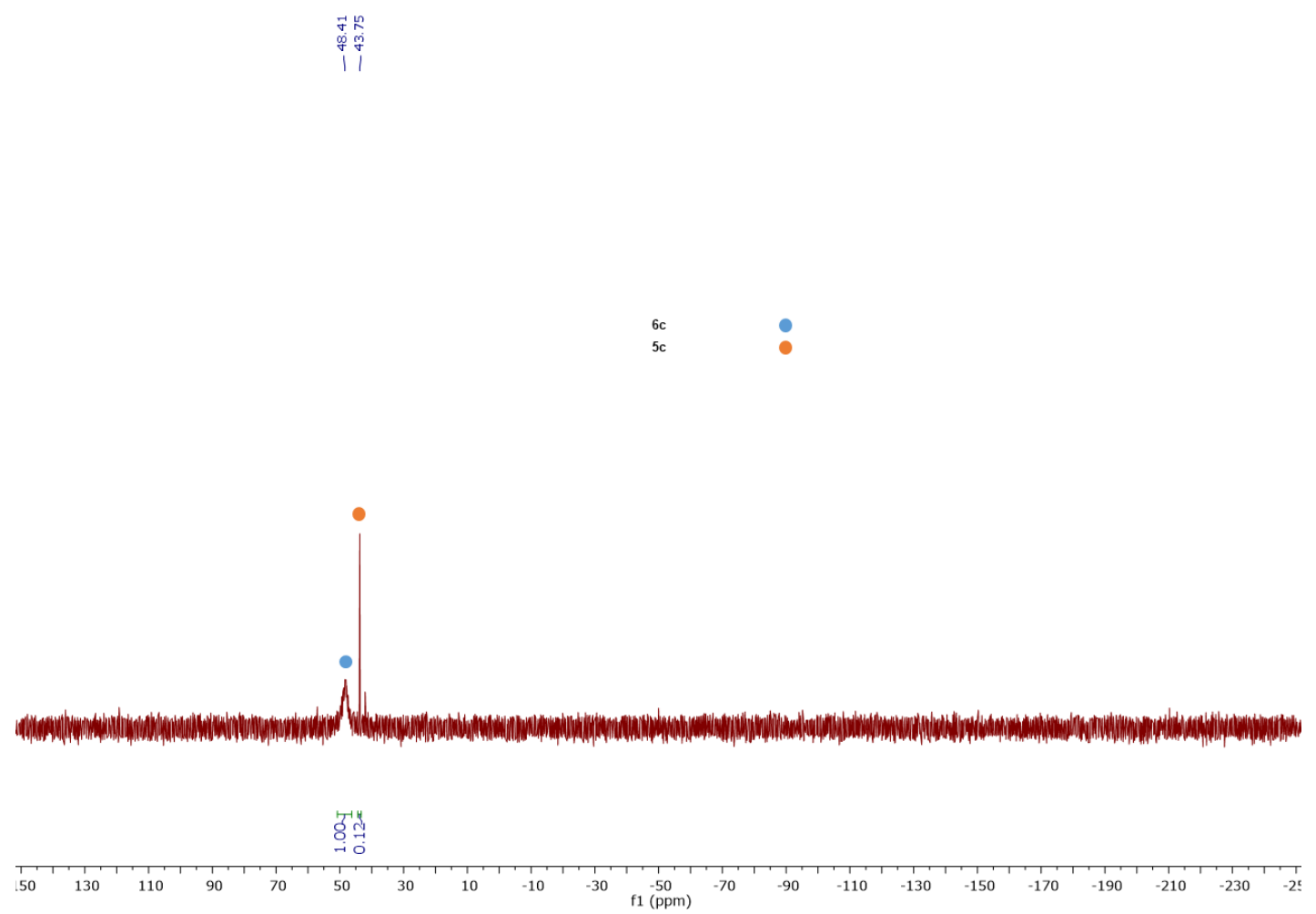

Figure S5. ${ }^{31} \mathrm{P}\left\{{ }^{1} \mathrm{H}\right\} \mathrm{NMR}\left(160 \mathrm{MHz}, \mathrm{THF}-\mathrm{d}_{8}, 298 \mathrm{~K}\right)$ spectrum of $4 \mathrm{c}$ into $6 \mathrm{c}$ reduction. 
Sample preparation for NMR characterization. In a $\mathrm{N}_{2}$-filled glovebox, [(dppe) $\left.\mathrm{NiBr}_{2}\right] \mathbf{4 c}$ (0.02 mmol, $12.3 \mathrm{mg}, 1.0$ equiv) was charged in a $2 \mathrm{~mL}$ Schlenk and suspended in THF- $d_{8}$ $(0.5 \mathrm{~mL}, 0.08 \mathrm{M})$. The Schlenk was sealed, taken out of the glovebox, cooled to $-40{ }^{\circ} \mathrm{C}$, and a $0.80 \mathrm{M}$ solution of vinyl magnesium bromide $2 \mathrm{a}$ in THF was added $(0.04 \mathrm{mmol}, 50 \mu \mathrm{L}, 2.0$ equiv). The reaction mixture was stirred at $-40^{\circ} \mathrm{C}$ for 5 minutes, then frozen in liquid nitrogen. The Schlenk was quickly introduced in a $\mathrm{N}_{2}$-filled glovebox, and the content of the tube was transferred in a J-Young NMR tube, which was immediately analyzed by NMR. NOTE: Due to the fluxional nature of the complex, the alkene carbons 1-4 were not observed. The complex slowly degrades at room temperature to the homoleptic complex [(dppe) $\left.{ }_{2} \mathrm{Ni}\right] \mathrm{5c}$, leading to gradual appearance of the corresponding signals.

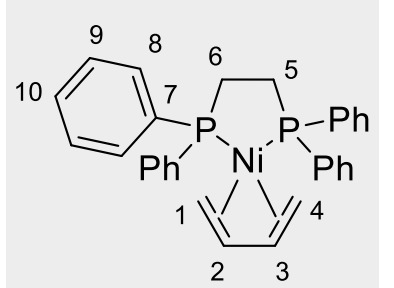

${ }^{1} \mathbf{H}$ NMR $\left(500 \mathrm{MHz}, \mathrm{THF}-\mathrm{d}_{8}\right) \delta(\mathrm{ppm})=7.54-7.52(\mathrm{~m}, 8 \mathrm{H}, \mathrm{H}-8), 7.24-$ $7.23(\mathrm{~m}, 12 \mathrm{H}, H-9, H-10), 5.09$ (s, 2H, $H-1$ or $H-2$ or $H-3$ or $H-4)$, 3.34$2.93(\mathrm{~m}, 4 \mathrm{H}, H-1$ or $H-2$ or $H-3$ or $H-4), 2.16\left(\mathrm{~d},{ }^{2} J_{H P}=14.4 \mathrm{~Hz}, 4 \mathrm{H}\right.$, $H-5, H-6)$.

${ }^{13} \mathrm{C}\left\{{ }^{1} \mathrm{H}\right\}$ NMR $\left(130 \mathrm{MHz}, \mathrm{THF}-\mathrm{d}_{8}\right) \delta(\mathrm{ppm})=139.4\left(\mathrm{~d},{ }^{1} \mathrm{~J}_{\mathrm{CP}}=27 \mathrm{~Hz}, \mathrm{C}-\right.$ 7), $133.2\left(\mathrm{~d},{ }^{2} \mathrm{~J}_{\mathrm{CP}}=14 \mathrm{~Hz}, \mathrm{CH}-8\right), 129.6(\mathrm{CH}-10), 129.0$ (d, $\left.{ }^{2} \mathrm{~J}_{\mathrm{CP}}=9.0 \mathrm{~Hz}, \mathrm{CH}-9\right), 29.70-28.74$ $\left(\mathrm{CH}_{2}-5\right.$ and $\left.\mathrm{CH}_{2}-6\right)$.

${ }^{31} \mathrm{P}\left\{{ }^{1} \mathrm{H}\right\}$ NMR $\left(160 \mathrm{MHz}, \mathrm{THF}-\mathrm{d}_{8}, \mathrm{~T}=298 \mathrm{~K}\right) \delta(\mathrm{ppm})=48.4(\mathrm{~s}$, broad$)$.

${ }^{31} \mathrm{P}\left\{{ }^{1} \mathrm{H}\right\}$ NMR $\left(160 \mathrm{MHz}, \mathrm{THF}-\mathrm{d}_{8}, \mathrm{~T}=173 \mathrm{~K}\right) \delta(\mathrm{ppm})=68.8$ (s, broad), 29.4 (s, broad). 


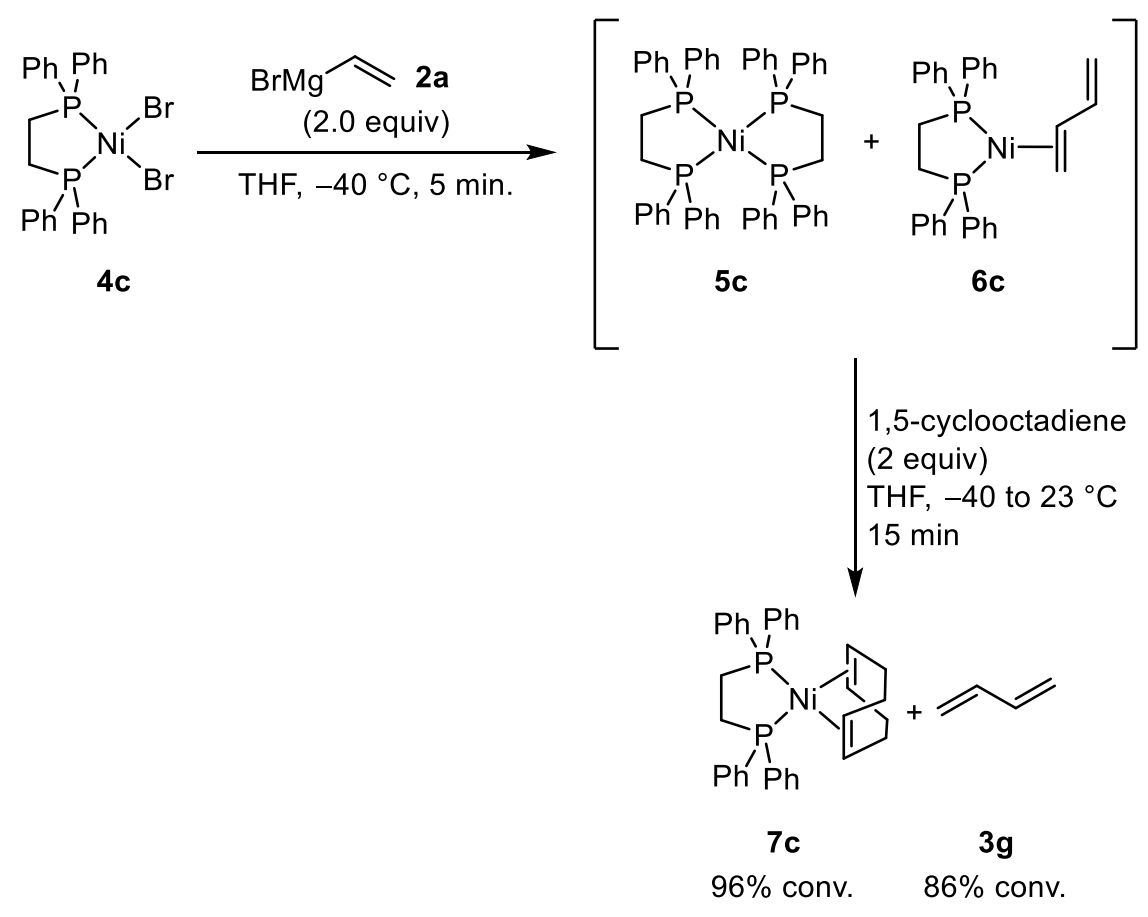

Figure S6.

1,5-cyclooctadiene trapping experiment. In a $\mathrm{N}_{2}$-filled glovebox, [(dppe) $\left.\mathrm{NiBr}_{2}\right]$ 4c $(0.1$ mmol, $61.7 \mathrm{mg}, 1.0$ equiv) was charged in a $2 \mathrm{~mL}$ Schlenk, followed by a $44.8 \mathrm{mM}$ stock solution of 1,3-di-tert-butyl-2-methoxy-5-methylbenzene in THF- $d_{8}(2.24 \mu \mathrm{mol}, 50 \mu \mathrm{L})$ and THF- $d_{8}(1.0 \mathrm{~mL}, 0.1 \mathrm{M})$. The Schlenk was sealed, taken out of the glovebox, cooled to $-40{ }^{\circ} \mathrm{C}$, and a $0.84 \mathrm{M}$ solution of vinyl magnesium bromide $2 \mathrm{a}$ in THF was added $(0.2 \mathrm{mmol}, 238 \mu \mathrm{L}$, 2.0 equiv). The reaction mixture was stirred at $-40^{\circ} \mathrm{C}$ for 5 minutes, then neat cyclooctadiene ( $0.20 \mathrm{mmol}, 25 \mu \mathrm{L}, 2.0$ equiv) was added. The resulting black suspension was stirred at -40 ${ }^{\circ} \mathrm{C}$ for 5 minutes, then allowed to warm to room temperature and stirred for 5 minutes. The Schlenk was introduced in a $\mathrm{N}_{2}$-filled glovebox, and the content of the tube was transferred to a J-Young NMR tube, which was immediately analyzed by NMR. ${ }^{1} \mathrm{H}$ NMR indicated conversion $>95 \%$ into the [(dppe) Ni(cod)] complex $\mathbf{7 c}$, along with $86 \%$ of butadiene $\mathbf{3 g}$. 


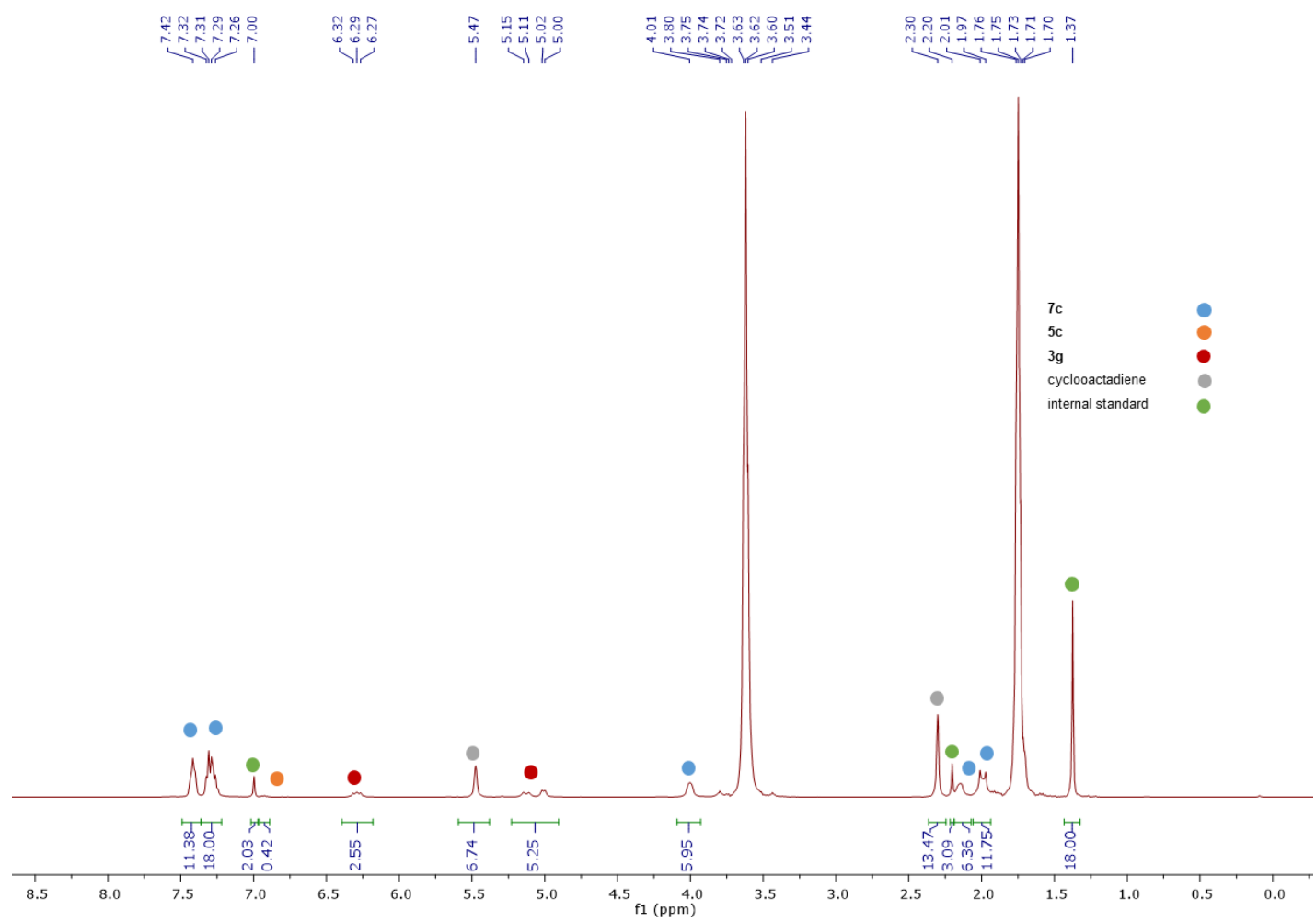

Figure S7. ${ }^{1} \mathrm{H}$ NMR (400 MHz, THF- $d_{8}, 298 \mathrm{~K}$ ) spectrum of $6 \mathrm{c}$ 1,5-cyclooctadiene trapping experiment.

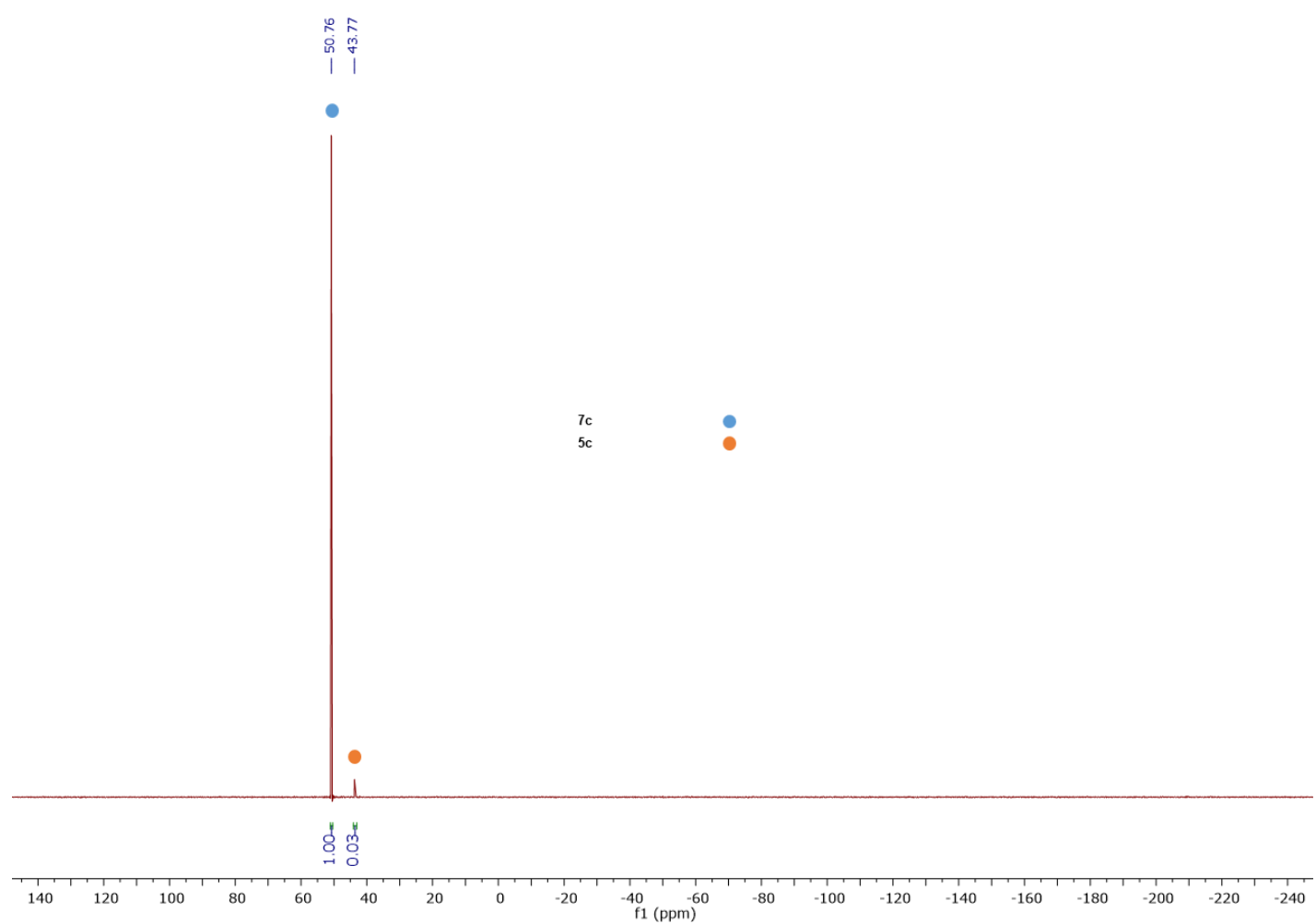

Figure S8. ${ }^{31} \mathrm{P}\left\{{ }^{1} \mathrm{H}\right\}$ NMR $\left(160 \mathrm{MHz}, \mathrm{THF}-d_{8}, 298 \mathrm{~K}\right)$ spectrum of $6 \mathbf{c}$ 1,5-cyclooctadiene trapping experiment. 


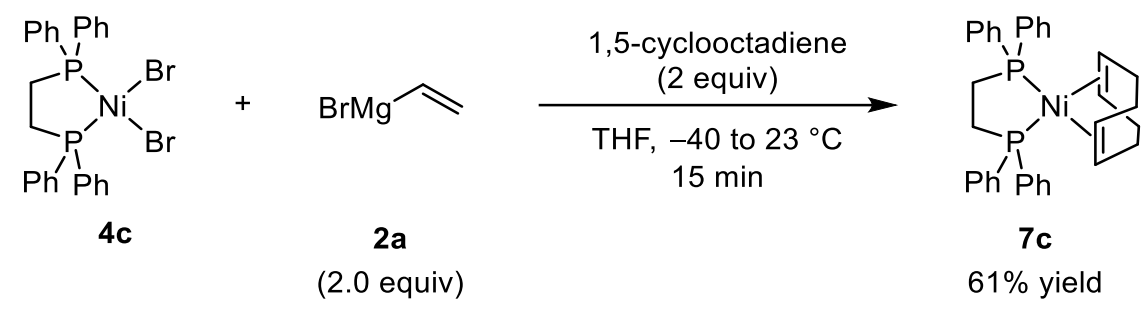

Figure S9.

Sample preparation for NMR characterization. In a $\mathrm{N}_{2}$-filled glovebox, $\left[(\mathrm{dppe}) \mathrm{NiCl}_{2}\right] \mathbf{4 c}$ (1.32 mmol, $700 \mathrm{mg}, 1$ equiv) was charged in a $100 \mathrm{~mL}$ Schlenk, followed by cyclooctadiene (6.63 mmol, $0.81 \mathrm{~mL}, 5$ equiv) and THF (50 mL, $0.026 \mathrm{M})$. The Schlenk was sealed, taken out of the glovebox, cooled to $-40{ }^{\circ} \mathrm{C}$, and a $0.86 \mathrm{M}$ solution of vinyl magnesium bromide $\mathbf{2 a}$ in THF was added dropwise $(2.65 \mathrm{mmol}, 3.1 \mathrm{~mL}, 2.0$ equiv). The resulting orange solution was warmed to room temperature over 30 minutes. The solution was evaporated under vacuum to afford a yellow solid which was suspended in $30 \mathrm{~mL}$ of toluene and filtered. Concentration of the filtrate led to a yellow solid which was recrystallized from THF/pentane (layer diffusion, $\left.30{ }^{\circ} \mathrm{C}\right)$ to afford [(dppe)Ni(cod)] 7c as bright yellow crystals $(0.80 \mathrm{mmol}, 454 \mathrm{mg}, 61 \%$ yield $)$.

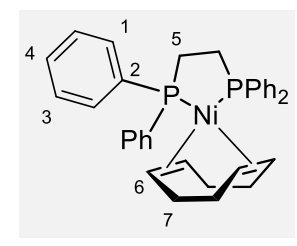

${ }^{1} \mathbf{H}$ NMR $\left(500 \mathrm{MHz}, \mathrm{THF}-d_{8}\right) \delta(\mathrm{ppm})=7.47-7.42(\mathrm{~m}, 8 \mathrm{H}, H-1), 7.35-7.26$ (m, 12H, H-3, H-4), 4.04-4.02 (m, 4H, H-6), 2.17-2.15 (m, 4H, H-7), 2.04$1.99(\mathrm{~m}, 8 \mathrm{H}, \mathrm{H}-5, \mathrm{H}-7)$.

${ }^{13} \mathbf{C}\left\{{ }^{1} \mathrm{H}\right\}$ NMR $\left(130 \mathrm{MHz}\right.$, THF- $\left.d_{8}\right) \delta(\mathrm{ppm})=140.3-140.1(\mathrm{~m}, \mathrm{C}-2), 132.8$ (tapp, $\left.J_{\mathrm{CP}}=6 \mathrm{~Hz}, \mathrm{CH}-3\right), 129.1(\mathrm{CH}-4), 129.0$ (tapp, $\left.J_{\mathrm{CP}}=4.0 \mathrm{~Hz}, \mathrm{CH}-1\right), 85.0\left(\mathrm{t}_{\text {app }}, J_{\mathrm{CP}}=3 \mathrm{~Hz}\right.$, $\mathrm{CH}-6), 32.4$ (tapp, $\left.\mathrm{J}_{\mathrm{CP}}=3 \mathrm{~Hz}, \mathrm{CH}_{2}-7\right), 30.2\left(\mathrm{t}_{\mathrm{app}}, \mathrm{J}=25 \mathrm{~Hz}, \mathrm{CH}_{2}-5\right)$.

${ }^{31} \mathrm{P}\left\{{ }^{1} \mathrm{H}\right\}$ NMR $\left(160 \mathrm{MHz}, \mathrm{THF}-d_{8}\right) \delta(\mathrm{ppm})=50.74(\mathrm{~s})$. 


\subsection{Reduction of $4 d$ into $6 d$}

\section{1,5-cyclooctadiene trapping}

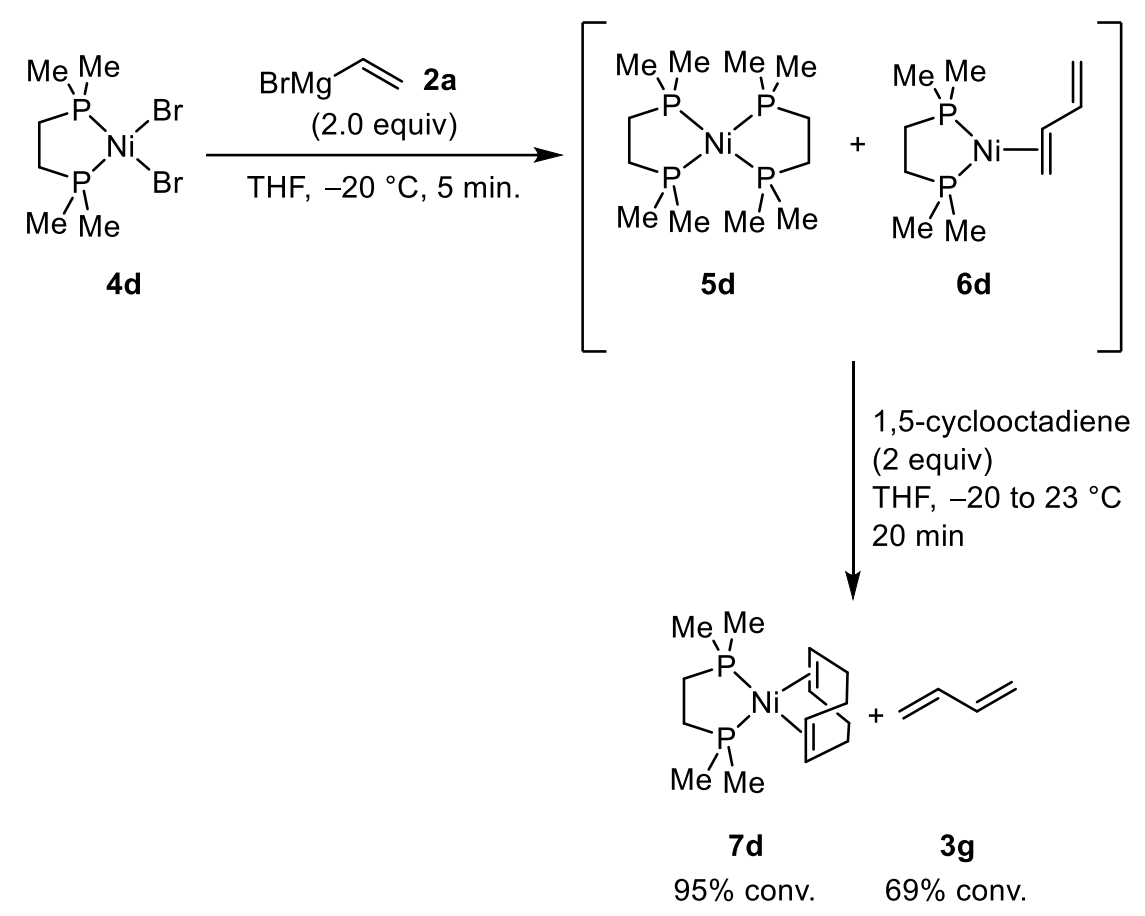

Figure S10.

In a $\mathrm{N}_{2}$-filled glovebox, [( $\left.\left.\mathrm{dmpe}\right) \mathrm{NiBr}_{2}\right] \mathbf{4 d}(0.02 \mathrm{mmol}, 7.4 \mathrm{mg}, 1.0$ equiv) was charged in a 2 $\mathrm{mL}$ Schlenk, followed by a $7.3 \mathrm{mM}$ stock solution of 1,3-di-tert-butyl-2-methoxy-5methylbenzene in THF- $d_{8}(0.36 \mathrm{mmol}, 50 \mu \mathrm{L})$ and THF- $d_{8}(0.5 \mathrm{~mL}, 0.04 \mathrm{M})$. The Schlenk was sealed, taken out of the glovebox, cooled to $-20^{\circ} \mathrm{C}$, and a $0.85 \mathrm{M}$ solution of vinyl magnesium bromide $2 \mathrm{a}$ in THF was added $(0.04 \mathrm{mmol}, 47 \mu \mathrm{L}, 2.0$ equiv). The reaction mixture was stirred at $-20^{\circ} \mathrm{C}$ for 5 minutes, then neat cyclooctadiene $(0.04 \mathrm{mmol}, 5 \mu \mathrm{L}, 2.0$ equiv) was added. The resulting red solution turned clear yellow over 20 minutes at $-20^{\circ} \mathrm{C}$ and was warmed to room temperature while being introduced in a $\mathrm{N}_{2}$-filled glovebox. The content of the tube was transferred in a J-Young NMR tube, which was immediately analyzed by NMR. ${ }^{1} \mathrm{H}$ NMR indicated a conversion of $95 \%$ into [(dmpe) $\mathrm{Ni}(\mathrm{cod})] \mathbf{7 d}$. 


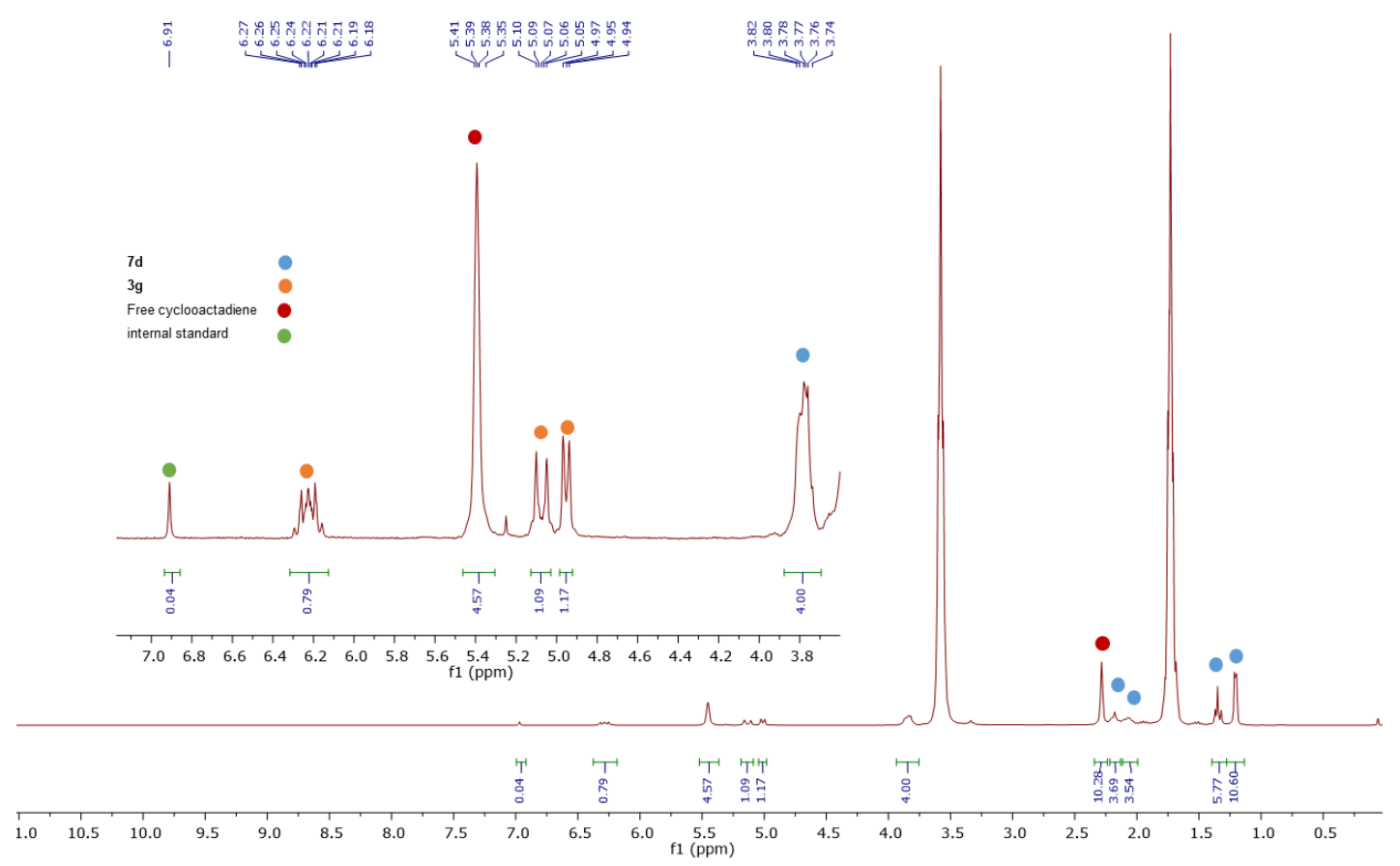

Figure S11. ${ }^{1} \mathrm{H}$ NMR (300 MHz, THF- $d_{8}, 298 \mathrm{~K}$ ) spectrum of $6 \mathbf{d}$ 1,5-cyclooctadiene trapping experiment.

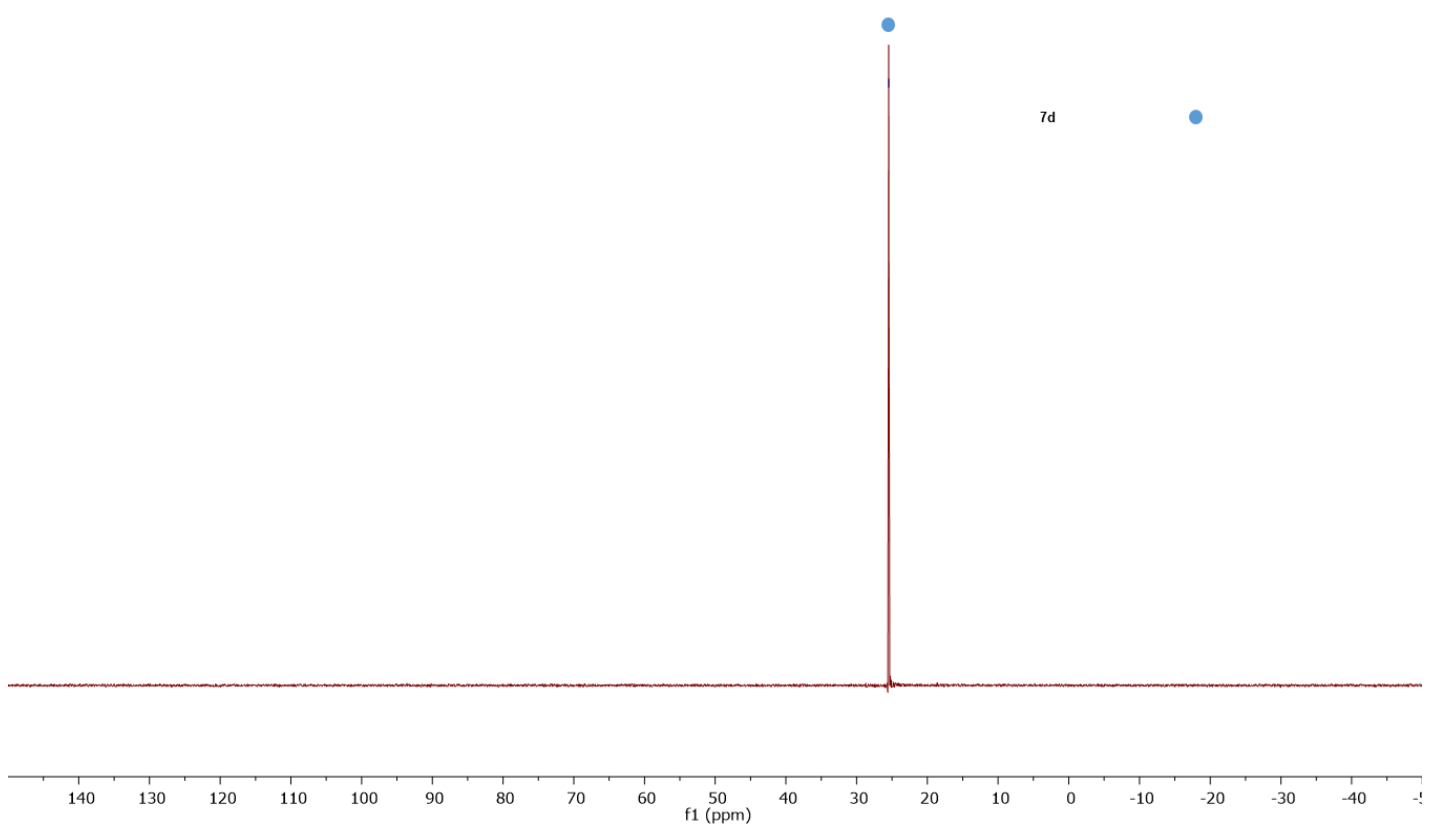

Figure S12. ${ }^{31} \mathrm{P}\left\{{ }^{1} \mathrm{H}\right\}$ NMR (160 MHz, THF- $\left.d_{8}, 298 \mathrm{~K}\right)$ spectrum of $6 \mathbf{d}$ 1,5-cyclooctadiene trapping experiment. 


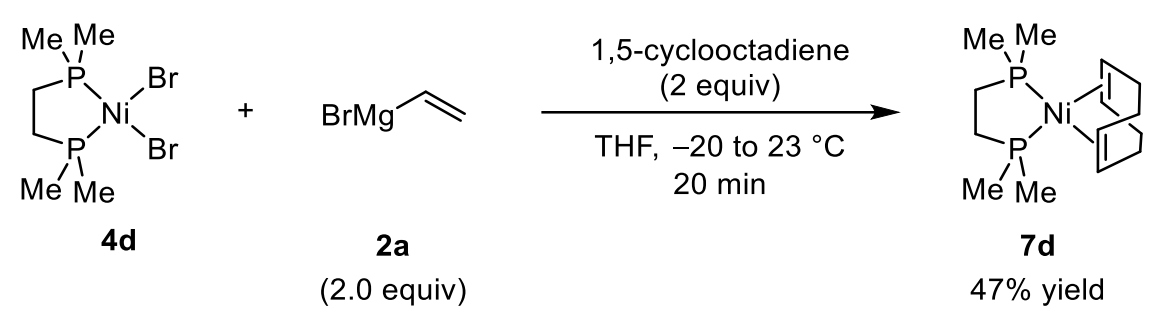

Figure S13.

Sample preparation for NMR characterization. In a $\mathrm{N}_{2}$-filled glovebox, [(dmpe) $\left.\mathrm{NiBr}_{2}\right] \mathbf{4 d}$ (300 mg, $0.82 \mathrm{mmol}, 1$ equiv) was weighed as a solid in a $50 \mathrm{~mL}$ Schlenk, cyclooctadiene (303 $\mu \mathrm{L}, 2.47 \mathrm{mmol}, 3$ equiv), and THF (14.2 mL) were added as well. Outside the glove box, the mixture was cooled to $-40^{\circ} \mathrm{C}$. To the cooled suspension was added vinyl magnesium bromide $2 \mathrm{a}$ (1.92 mL, 0.9M/THF, $1.73 \mathrm{mmol}, 2.1$ equiv) dropwise. After 2 hours the color changed from an orange suspension to a clear orange solution which was warmed to room temperature before being put back in a glove box. The solution was evaporated under vacuum. To the remaining solid was added pentane and the obtained suspension was filtered $(4 \times 24$ $\mathrm{mL}$ ). A white/yellow solid remained insoluble. The filtrate was then fully evaporated. We obtained a pale yellow solid. This solid was recrystallized from a supersaturated solution in pentane at $-30^{\circ} \mathrm{C}$. Yellow crystals of $\mathbf{7 d}$, suitable for X-ray analysis were obtained, $126 \mathrm{mg}$ in three crops, $47 \%$ yield.

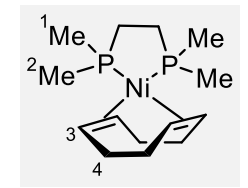

${ }^{1} \mathrm{H}$ NMR $\left(500 \mathrm{MHz}, \mathrm{THF}-\mathrm{d}_{8}\right) \delta(\mathrm{ppm})=3.90\left(\mathrm{~d},{ }^{3} J_{H H}=5.8 \mathrm{~Hz}, 4 \mathrm{H}, \mathrm{H}-3\right), 2.24-$ $2.09(\mathrm{~m}, 4 \mathrm{H}, H-4), 1.39\left(\mathrm{~d},{ }^{3} J_{H H}=14.8 \mathrm{~Hz}, 4 \mathrm{H}, H-2\right), 1.26-1.25(\mathrm{~m}, 12 \mathrm{H}, H-1)$. ${ }^{13} \mathrm{C}\left\{{ }^{1} \mathrm{H}\right\}$ NMR $\left(130 \mathrm{MHz}, \mathrm{THF}-d_{8}\right) \delta(\mathrm{ppm})=78.68\left(\mathrm{t}, J_{C P}=3.7 \mathrm{~Hz}, \mathrm{CH}-3\right), 32.91$ (t, $\left.J_{C P}=4.0 \mathrm{~Hz}, \mathrm{CH}_{2}-4\right), 31.64$ (t, $\left.J_{C P}=24.9 \mathrm{~Hz}, C \mathrm{H}_{3}-2\right), 16.59$ (t, $\left.J_{C P}=9.0 \mathrm{~Hz}, C_{3}-1\right)$. ${ }^{31} \mathrm{P}\left\{{ }^{1} \mathrm{H}\right\}$ NMR $\left(160 \mathrm{MHz}, \mathrm{THF}-\mathrm{d}_{8}\right) \delta(\mathrm{ppm})=25.51(\mathrm{~s})$. 


\subsection{Ni-catalyzed vinylation of $1 \mathrm{a}$ with in situ generated $\mathrm{Ni}(0) 6 \mathrm{c}$ or $6 \mathrm{~d}$}<smiles>C=C(O[P+](=O)CC)c1ccc(CC(C)C)cc1</smiles>

$1 \mathrm{a}$

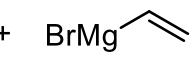

(1.0 equiv)

2a
$6 \mathrm{c}$ or $6 \mathrm{~d}$

generated in situ

$(2.5 \mathrm{~mol} \%)$

THF [0.25], $23^{\circ} \mathrm{C}, 1 \mathrm{~h}$<smiles>C=Cc1ccc(CC(C)C)cc1</smiles>

3aa

6c: $86 \%$ conv.

6d: $92 \%$ conv.

Figure S14.

In a $\mathrm{N}_{2}$-filled glovebox, the appropriate Ni precatalyst $\mathbf{4 c}$ or $\mathbf{4 d}(0.025,5 \mathrm{~mol} \%)$ was weighted as solid in a $2 \mathrm{~mL}$ Schlenk and suspended in $440 \mu \mathrm{L}$ of anhydrous and degassed THF. Enol phosphate 1a was charged into a $5 \mathrm{~mL}$ Schlenk and dissolved in $1.14 \mathrm{~mL}$ of anhydrous and degassed THF. Outside the glovebox, the enol phosphate solution was cooled to $0{ }^{\circ} \mathrm{C}$ with an ice bath and the nickel suspension was cooled to $-20^{\circ} \mathrm{C} .61 \mu \mathrm{L}$ of vinyl magnesium bromide $2 \mathbf{a}$ was added into the orange nickel suspension which became a red solution over 5 minutes. $610 \mu \mathrm{L}$ of vinyl magnesium bromide $\mathbf{2 a}$ was added into the cold enol phosphate 1a solution. Subsequently, $250 \mu \mathrm{L}$ of the preformed nickel butadiene complex $6 \mathbf{c}$ or $\mathbf{6 d}$ solution was added to the $5 \mathrm{~mL}$ Schlenk. After 10 minutes, the ice-bath was removed and the reaction mixture was stirred for 1 hour at room temperature. The reaction was then quenched by addition of a saturated solution of ammonium chloride and extracted with ethyl acetate. The organic layers were dried over sodium sulfate, filtered and the solvent removed under vacuum affording the crude residue that was analyzed by ${ }^{1} \mathrm{H}$ NMR in order to estimate consumption of and conversion.

Procedure using 4c gave $86 \%$ conversion into diene 3aa for $>95 \%$ consumption of enol phosphate 1a.

Procedure using 4d gave $92 \%$ conversion into diene 3aa for $>95 \%$ consumption of enol phosphate 1a. 


\section{Oxidative addition}

\subsection{Oxidative addition complexes $9 \mathrm{c}$ and $10 \mathrm{c}$}

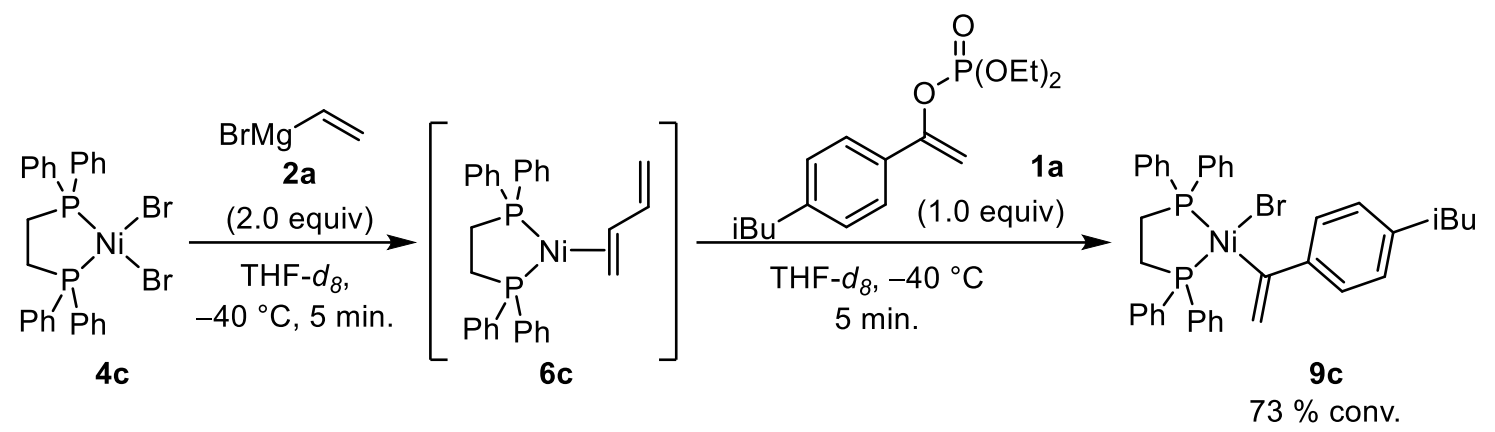

Figure S15.

Oxidative addition using 1a. In a $\mathrm{N}_{2}$-filled glovebox, [(dppe) $\left.\mathrm{NiBr}_{2}\right] \mathbf{4 c}(0.01 \mathrm{mmol}, 6.2 \mathrm{mg}$, 1.0 equiv) was charged in a $2 \mathrm{~mL}$ Schlenk, followed by a $44.8 \mathrm{mM}$ stock solution of 1,3-di-tertbutyl-2-methoxy-5-methylbenzene in THF- $d_{8}(2.24 \mu \mathrm{mol}, 50 \mu \mathrm{L}, 0.22$ equiv) and THF $(0.5 \mathrm{~mL}$, $0.02 \mathrm{M}$ ). The Schlenk was sealed, taken out of the glovebox, cooled to $-40{ }^{\circ} \mathrm{C}$, and a $0.80 \mathrm{M}$ solution of vinyl magnesium bromide $2 \mathrm{a}$ in THF was added $(0.02 \mathrm{mmol}, 25 \mu \mathrm{L}, 2.0$ equiv). The reaction mixture was stirred at $-40^{\circ} \mathrm{C}$ for 5 minutes, then a $0.2 \mathrm{M}$ stock solution of diethyl (1(4-isobutylphenyl)vinyl) phosphate 1a in THF (0.01 mmol, $50 \mu \mathrm{L}, 1.0$ equiv) was added. The resulting black suspension was stirred at $-40^{\circ} \mathrm{C}$ for 10 minutes, then concentrated in vacuum at $-40^{\circ} \mathrm{C}$. The residual brown oil was dissolved in THF- $d_{8}(0.5 \mathrm{~mL})$, the resulting solution was frozen in liquid nitrogen, the Schlenk was rapidly introduced in a $\mathrm{N}_{2}$-filled glovebox, and the solution was transferred in a $\mathrm{J}$-Young tube which was immediately analyzed by ${ }^{1} \mathrm{H}$ and ${ }^{31} \mathrm{P}$ NMR at $-30{ }^{\circ} \mathrm{C} .{ }^{1} \mathrm{H}$ NMR indicated a $73 \%$ conversion into the oxidative addition complex $9 \mathrm{c}$ and $77 \%$ consumption of enol phosphate $\mathbf{1 a}$. 


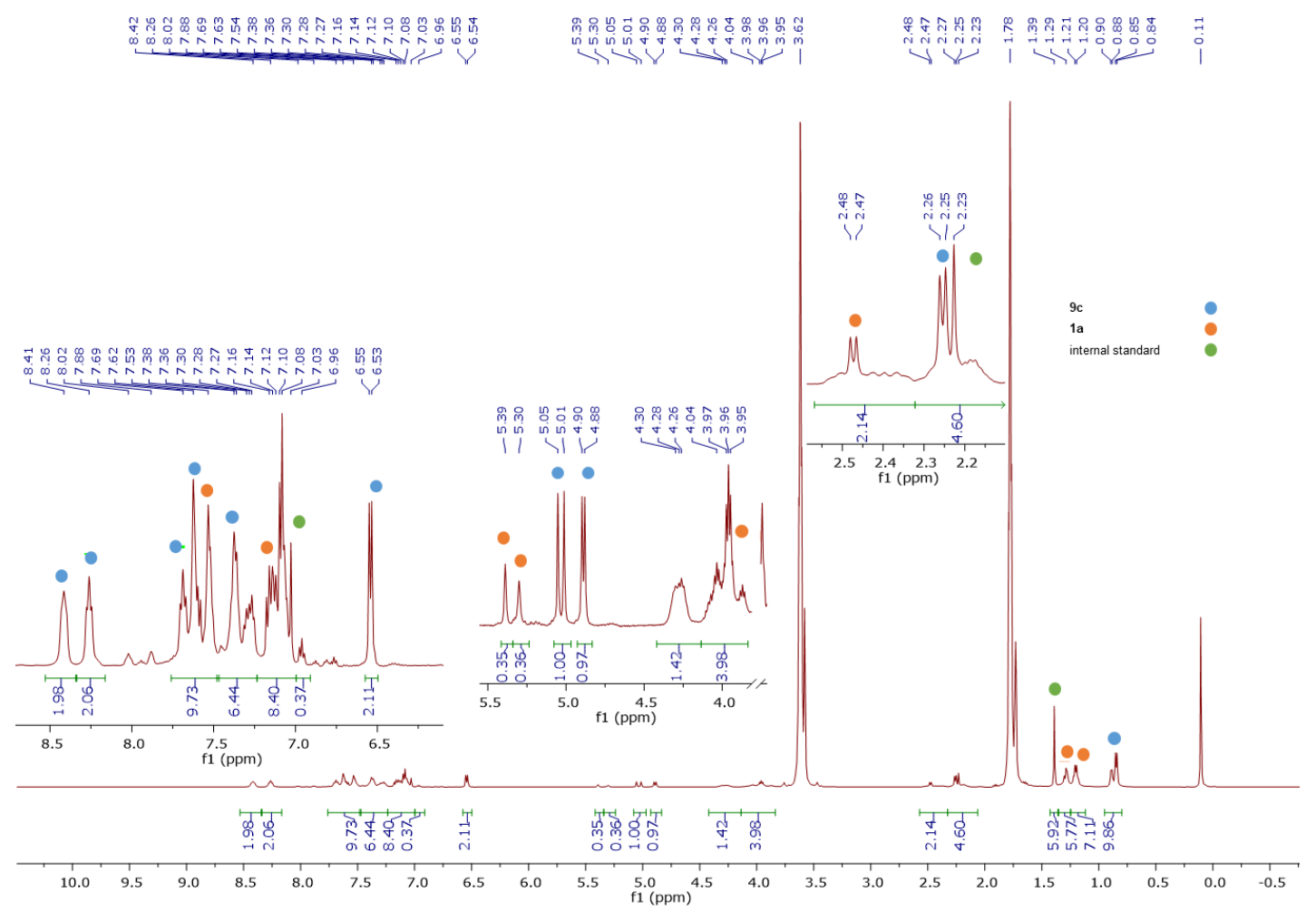

Figure S16. ${ }^{1} \mathrm{H}$ NMR $\left(300 \mathrm{MHz}, \mathrm{THF}-\mathrm{d}_{8}, 243 \mathrm{~K}\right)$ spectrum of the oxidative addition complex $9 c$ starting from $1 a$ and $4 c$.

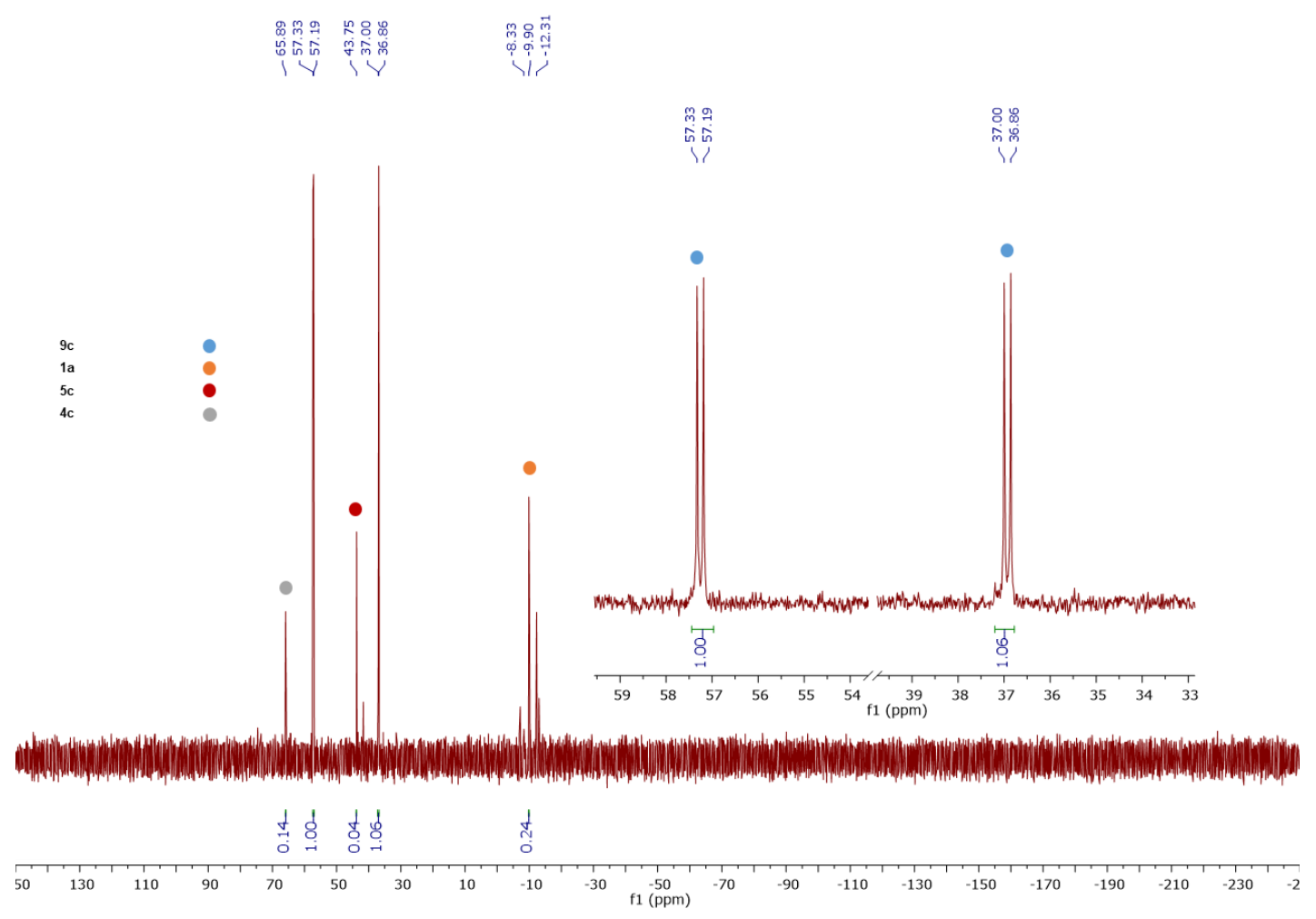

Figure S17. ${ }^{31} \mathrm{P}\left\{{ }^{1} \mathrm{H}\right\}$ NMR $\left(160 \mathrm{MHz}, \mathrm{THF}-\mathrm{d}_{8}, 243 \mathrm{~K}\right)$ spectrum of the oxidative addition complex $9 \mathrm{c}$ starting from $\mathbf{1 a}$ and $\mathbf{4 c}$. 


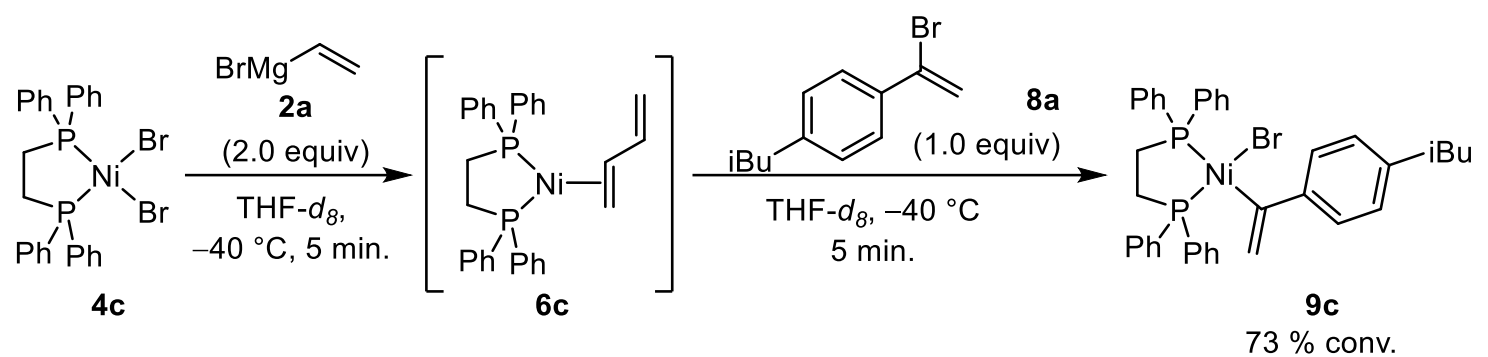

Figure S18.

Oxidative addition using 8a. In a $\mathrm{N}_{2}$-filled glovebox, [(dppe) $\left.\mathrm{NiBr}_{2}\right] \mathbf{4 c}(0.01 \mathrm{mmol}, 6.2 \mathrm{mg}$, 1.0 equiv) was charged in a $2 \mathrm{~mL}$ Schlenk, followed by a $44.8 \mathrm{mM}$ stock solution of 1,3-di-tertbutyl-2-methoxy-5-methylbenzene in THF- $d_{8}(2.24 \mu \mathrm{mol}, 50 \mu \mathrm{L}, 0.22$ equiv) and THF $(0.5 \mathrm{~mL}$, $0.02 \mathrm{M})$. The Schlenk was sealed, taken out of the glovebox, cooled to $-40{ }^{\circ} \mathrm{C}$, and a $0.80 \mathrm{M}$ solution of vinyl magnesium bromide $2 \mathrm{a}$ in THF was added ( $0.02 \mathrm{mmol}, 25 \mu \mathrm{L}, 2.0$ equiv). The reaction mixture was stirred at $-40{ }^{\circ} \mathrm{C}$ for 5 minutes, then a $0.2 \mathrm{M}$ stock 1 -(1-bromovinyl)-4isobutylbenzene $8 \mathrm{a}$ in THF $(0.01 \mathrm{mmol}, 50 \mu \mathrm{L}, 1.0$ equiv) was added. The resulting black suspension was stirred at $-40{ }^{\circ} \mathrm{C}$ for $10 \mathrm{~min}$, then concentrated in vacuum at $-40{ }^{\circ} \mathrm{C}$. The residual brown oil was dissolved in THF- $d_{8}(0.5 \mathrm{~mL})$, the resulting solution was frozen in liquid nitrogen, the Schlenk was rapidly introduced in a $\mathrm{N}_{2}$-filled glovebox, and the solution was transferred in a J-Young tube which was immediately analyzed by ${ }^{1} \mathrm{H}$ and ${ }^{31} \mathrm{P}$ NMR at $-30{ }^{\circ} \mathrm{C}$. ${ }^{1} \mathrm{H}$ NMR indicated a $73 \%$ conversion into the oxidative addition complex $9 \mathrm{c}$ and $>95 \%$ consumption of 1-(1-bromovinyl)-4-isobutylbenzene $\mathbf{8 a}$. 


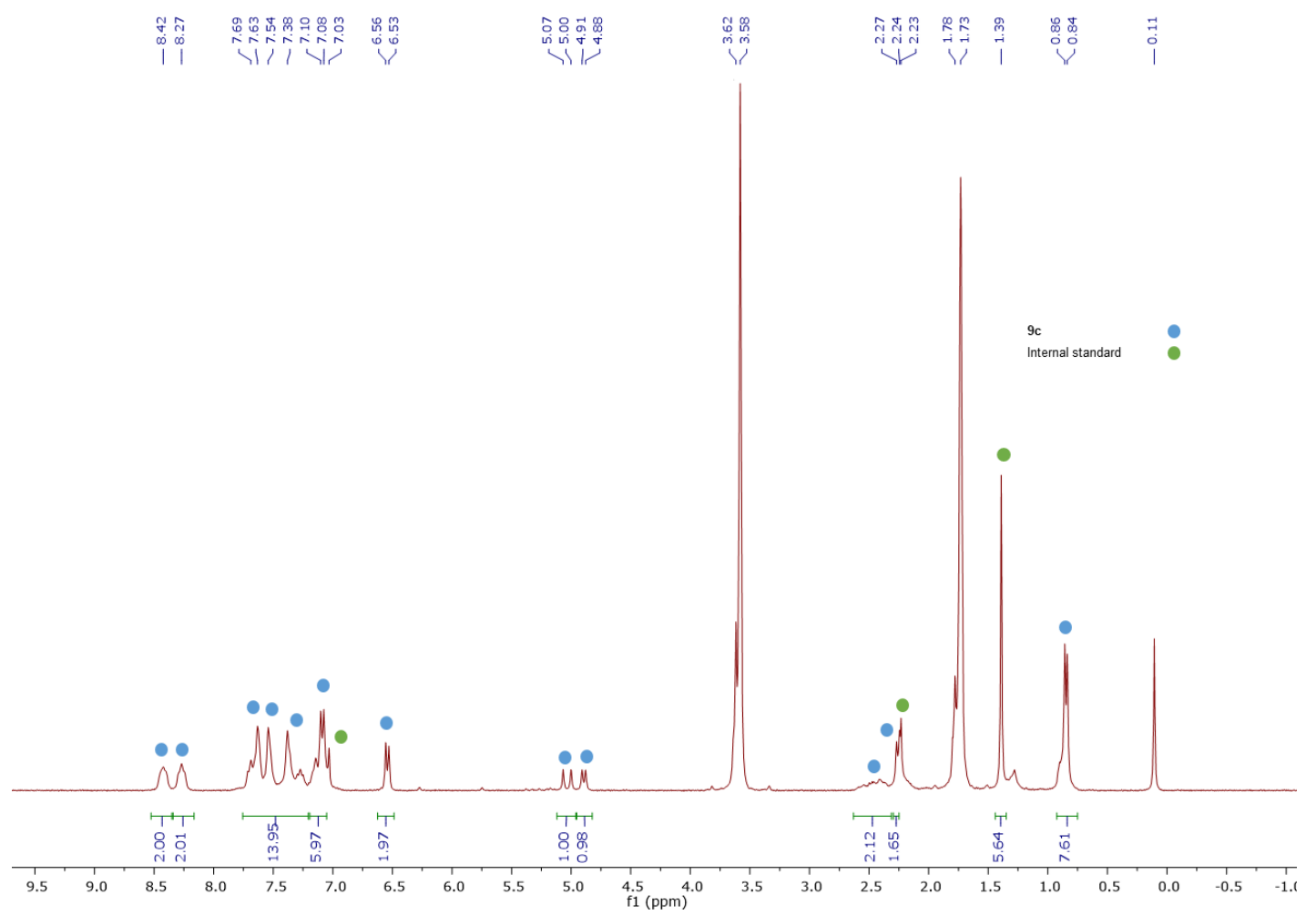

Figure S19. ${ }^{1} \mathrm{H}$ NMR $\left(300 \mathrm{MHz}, \mathrm{THF}-\mathrm{d}_{8}, 243 \mathrm{~K}\right)$ spectrum of the oxidative addition complex $9 c$ starting from $8 a$ and $4 c$.

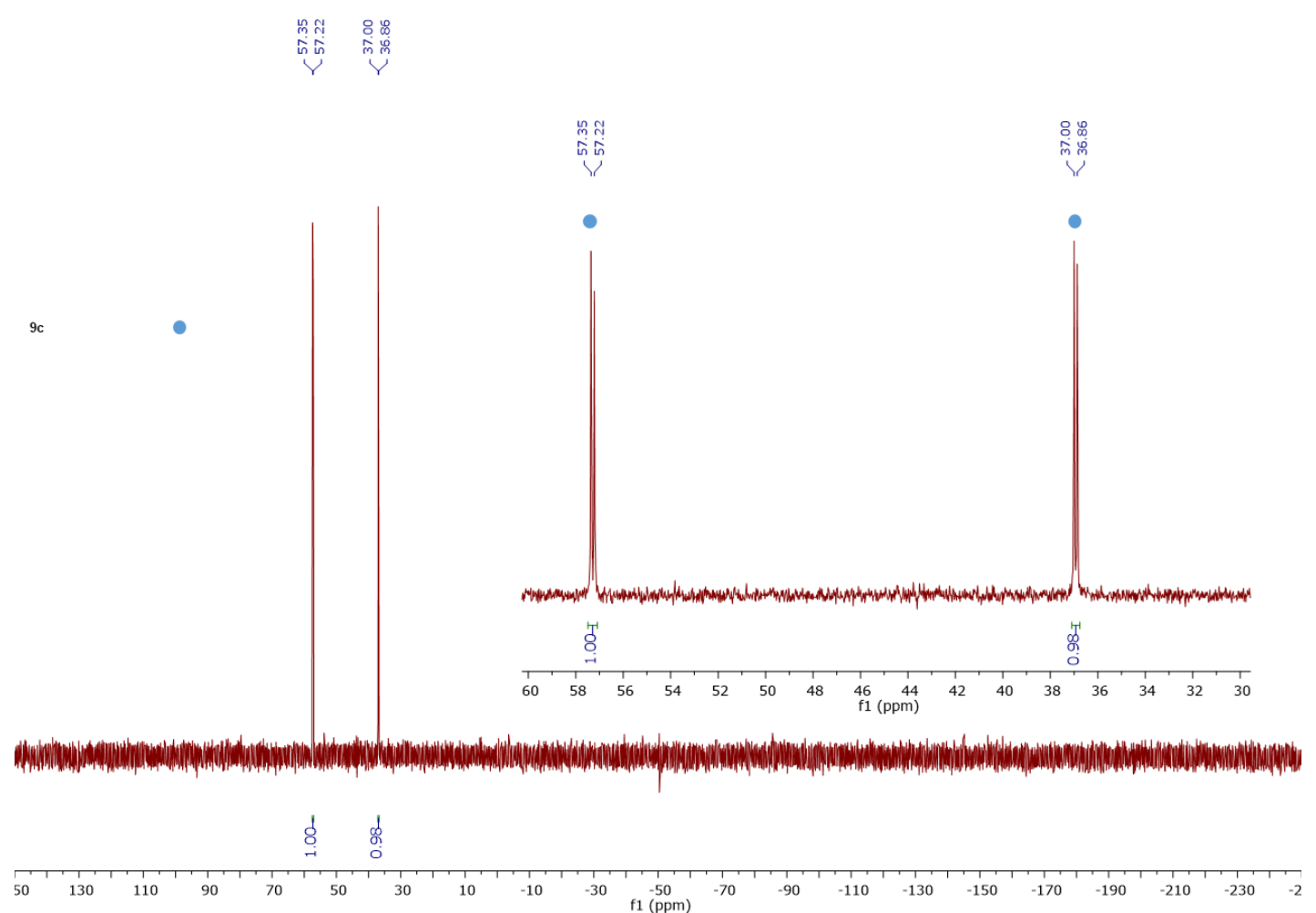

Figure S20. ${ }^{31} \mathrm{P}\left\{{ }^{1} \mathrm{H}\right\}$ NMR $\left(160 \mathrm{MHz}, \mathrm{THF}-d_{8}, 243 \mathrm{~K}\right)$ spectrum of the oxidative addition complex $9 \mathbf{c}$ starting from $8 \mathbf{a}$ and $\mathbf{4 c}$. 


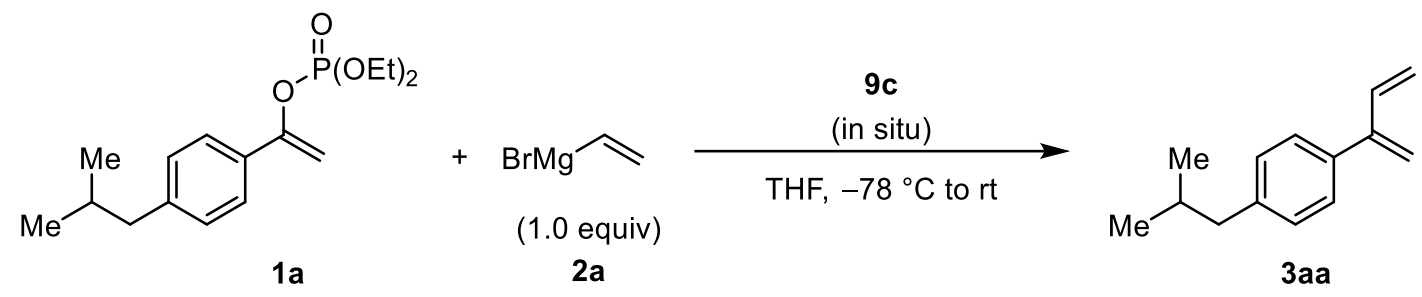

Figure S21.

Catalytic relevance of in situ generated $9 c$. In a $\mathrm{N}_{2}$-filled glovebox, [(dppe) $\left.\mathrm{NiBr}_{2}\right] \mathbf{4 c}(0.015$ mmol, $9.2 \mathrm{mg}, 2.5 \mathrm{~mol} \%$ ) was charged in a $5 \mathrm{~mL}$ Schlenk, followed by THF (1.56 mL, $0.25 \mathrm{M}$ final concentration). The Schlenk was sealed, taken out of the glovebox, cooled to $-20{ }^{\circ} \mathrm{C}$, and a $0.80 \mathrm{M}$ solution of vinyl magnesium bromide $2 \mathrm{a}$ in THF was added $(0.03 \mathrm{mmol}, 38 \mu \mathrm{L}$, $5 \mathrm{~mol} \%$ ). The reaction mixture was stirred at $-20^{\circ} \mathrm{C}$ for 5 minutes, then a $0.2 \mathrm{M}$ stock solution of 1-(1-bromovinyl)-4-isobutylbenzene 8a in THF $(0.015 \mathrm{mmol}, 50 \mu \mathrm{L}, 2.5 \mathrm{~mol} \%)$ was added. The resulting brown suspension was stirred at $-20{ }^{\circ} \mathrm{C}$ for $10 \mathrm{~min}$ before being cooled to -78 ${ }^{\circ} \mathrm{C}$. To the cooled mixture were added at the same time diethyl (1-(4-isobutylphenyl)vinyl) phosphate 1a ( $0.6 \mathrm{mmol}, 187 \mathrm{mg}, 1$ equiv) and a $0.80 \mathrm{M}$ solution of vinyl magnesium bromide 2a in THF ( $0.6 \mathrm{mmol}, 750 \mu \mathrm{L}, 1$ equiv). The Schlenk was then removed from the cold bath and the reaction mixture was stirred at room temperature for 1 hour. The reaction was quenched by addition of $5.0 \mathrm{~mL}$ of a saturated solution of ammonium chloride at $0{ }^{\circ} \mathrm{C}$ and extracted with ethyl acetate $(3 \times 25 \mathrm{~mL})$. The organic layers were combined, dried over sodium sulfate, filtered and the solvent removed under vacuum. The crude residue was immediately analyzed by ${ }^{1} \mathrm{H}$ NMR with an internal standard (1,3-di-tert-butyl-2-methoxy-5-methylbenzene). ${ }^{1} \mathrm{H}$ NMR indicated a $63 \%$ conversion into diene 3 and $>95 \%$ consumption of diethyl (1-(4isobutylphenyl)vinyl) phosphate $\mathbf{1 a}$.

Sample preparation for recrystallization. In a $\mathrm{N}_{2}$-filled glovebox, [(dppe) $\left.\mathrm{NiBr}_{2}\right] \mathbf{4 c}(0.40$ mmol, $247 \mathrm{mg}, 1.0$ equiv) was charged in a $25 \mathrm{~mL}$ Schlenk, followed by THF (10 mL, 0.04 $\mathrm{M})$. The Schlenk was sealed, taken out of the glovebox, cooled to $-40{ }^{\circ} \mathrm{C}$, and a $0.80 \mathrm{M}$ solution of vinyl magnesium bromide $2 \mathbf{a}$ in THF was added $(0.80 \mathrm{mmol}, 1.0 \mathrm{~mL}, 2.0$ equiv). The reaction mixture was stirred at $-40{ }^{\circ} \mathrm{C}$ for 5 minutes, then neat 1-(1-bromovinyl)-4isobutylbenzene $8 \mathrm{a}$ was added $(0.4 \mathrm{mmol}, 95.6 \mathrm{mg}, 1.0$ equiv). The resulting black suspension was stirred at $-40{ }^{\circ} \mathrm{C}$ for 10 minutes, then concentrated in vacuum at $-40^{\circ} \mathrm{C}$. The residue was dissolved in THF $(5.0 \mathrm{~mL})$, followed by dioxane $(3.20 \mathrm{mmol}, 0.75 \mathrm{~mL}, 8.0$ equiv). The suspension was stirred at $-40^{\circ} \mathrm{C}$ for 30 minutes, then decanted for 30 minutes. The reaction mixture was cooled to $-78{ }^{\circ} \mathrm{C}$ and the supernatant was transferred by cannula into a Schlenk cooled to $-78{ }^{\circ} \mathrm{C}$. The resulting solution was concentrated down to ca. $0.5 \mathrm{~mL}$ and frozen in liquid nitrogen. The Schlenk was rapidly introduced in a $\mathrm{N}_{2}$-filled glovebox, and crystals of 
suitable quality for an X-ray analysis were grown by diethyl ether vapor diffusion into the THF solution at $-30^{\circ} \mathrm{C}$.

Sample preparation for NMR characterization. In a $\mathrm{N}_{2}$-filled glovebox, [(dppe) $\left.\mathrm{NiBr}_{2}\right](0.01$ mmol, $6.2 \mathrm{mg}, 1.0$ equiv) was charged in a $2 \mathrm{~mL}$ Schlenk, followed by THF ( $0.5 \mathrm{~mL}, 0.02 \mathrm{M})$. The Schlenk was sealed, taken out of the glovebox, cooled to $-40{ }^{\circ} \mathrm{C}$, and a $0.80 \mathrm{M}$ solution of vinyl magnesium bromide in THF was added ( $0.02 \mathrm{mmol}, 25 \mu \mathrm{L}, 2.0$ equiv). The reaction mixture was stirred at $-40{ }^{\circ} \mathrm{C}$ for 5 minutes, then a $0.2 \mathrm{M}$ stock 1-(1-bromovinyl)-4isobutylbenzene in THF $(0.01 \mathrm{mmol}, 50 \mu \mathrm{L}, 1.0$ equiv) was added. The resulting black suspension was stirred at $-40^{\circ} \mathrm{C}$ for 10 minutes, then concentrated under vacuum at $-40^{\circ} \mathrm{C}$. The residual brown oil was dissolved in THF- $d_{8}(0.5 \mathrm{~mL})$, the resulting solution was frozen in liquid nitrogen, the Schlenk was rapidly introduced in a $\mathrm{N}_{2}$-filled glovebox, and the solution was transferred in a J-Young tube which was immediately analyzed by NMR at $-30^{\circ} \mathrm{C}$.

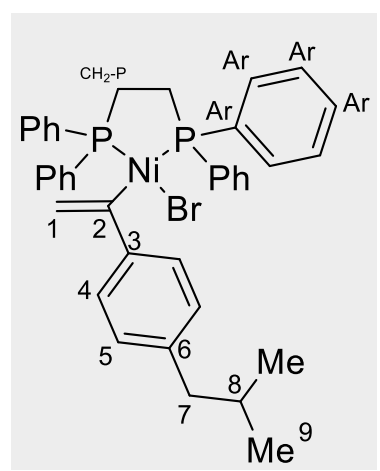

${ }^{1}$ H NMR $\left(500 \mathrm{MHz}, \mathrm{THF}-\mathrm{d}_{8}\right) \delta(\mathrm{ppm})=8.46-8.36(\mathrm{~m}, 2 \mathrm{H}, \mathrm{H}-\mathrm{Ar}), 8.30-$ $8.22(\mathrm{~m}, 2 \mathrm{H}, H-\mathrm{Ar}), 7.70-7.00(\mathrm{~m}, 18 \mathrm{H}, \mathrm{H}-\mathrm{Ar}, \mathrm{H}-5), 6.54\left(\mathrm{~d},{ }^{3} \mathrm{JHH}_{\mathrm{HH}}=\right.$ $8.0 \mathrm{~Hz}, 2 \mathrm{H}, H-4), 5.04\left(\mathrm{~d},{ }^{4} J_{\mathrm{HP}}=19.8 \mathrm{~Hz}, 1 \mathrm{H}, H-1\right), 4.89\left(\mathrm{~d},{ }^{4} J_{\mathrm{HP}}=8.8\right.$ $\mathrm{Hz}, 1 \mathrm{H}, \mathrm{H}-1), 2.54-2.32\left(\mathrm{~m}, 2 \mathrm{H}, \mathrm{CH}_{2}-\mathrm{P}\right), 2.26\left(\mathrm{~d},{ }^{3} \mathrm{~J}_{\mathrm{HH}}=7.2 \mathrm{~Hz}, 2 \mathrm{H}, \mathrm{H}-\right.$ 7), 2.23-2.11 (m, 2H, CH

${ }^{13} \mathrm{C}\left\{{ }^{1} \mathrm{H}\right\}$ NMR $\left(130 \mathrm{MHz}, \mathrm{THF}-\mathrm{d}_{8}\right) \delta(\mathrm{ppm})=167.7\left(\mathrm{dd},{ }^{2} \mathrm{JPC}_{\mathrm{PC}}=83,34\right.$ $\mathrm{Hz}$ ), 145.1 (C-3), $138.4(C-6), 136.4$ (d, $\left.J_{P C}=11 \mathrm{~Hz}, \mathrm{CH}-\mathrm{Ar}\right), 135.1$ (d, $\left.J_{P C}=11 \mathrm{~Hz}, C \mathrm{H}-\mathrm{Ar}\right), 134.3\left(\mathrm{~d}, J_{P C}=11 \mathrm{~Hz},\right), 133.8\left(\mathrm{~d}, J_{P C}=9 \mathrm{~Hz}, \mathrm{CH}-\right.$ Ar), 129.8 (d, $\left.J_{P C}=7 \mathrm{~Hz}, C H-A r\right), 129.7$ (d, $\left.J_{P C}=9 \mathrm{~Hz}, C H-A r\right), 129.1$ (d, $\left.J_{P C}=9 \mathrm{~Hz}, C H-A r\right)$, $128.6\left(\mathrm{~d}, J_{P C}=10 \mathrm{~Hz}, \mathrm{CH}-\mathrm{Ar}\right), 128.1(\mathrm{CH}-4), 117.3\left(\mathrm{CH}_{2}-1\right), 46.1\left(\mathrm{CH}_{2}-7\right), 31.6(\mathrm{CH}-8), 30.4$ (dd, $\left.J_{P C}=28,21 \mathrm{~Hz}, \mathrm{CH}_{2}-\mathrm{P}\right), 22.9\left(\mathrm{CH}_{3}-9\right)$.

${ }^{31} \mathrm{P}\left\{{ }^{1} \mathrm{H}\right\}$ NMR $\left(160 \mathrm{MHz}, \mathrm{THF}-\mathrm{d}_{8}\right) \delta(\mathrm{ppm})=57.3\left(\mathrm{~d},{ }^{2} \mathrm{JPP}=16 \mathrm{~Hz}\right), 36.9\left(\mathrm{~d},{ }^{2} J_{\mathrm{PP}}=16.5 \mathrm{~Hz}\right)$. 


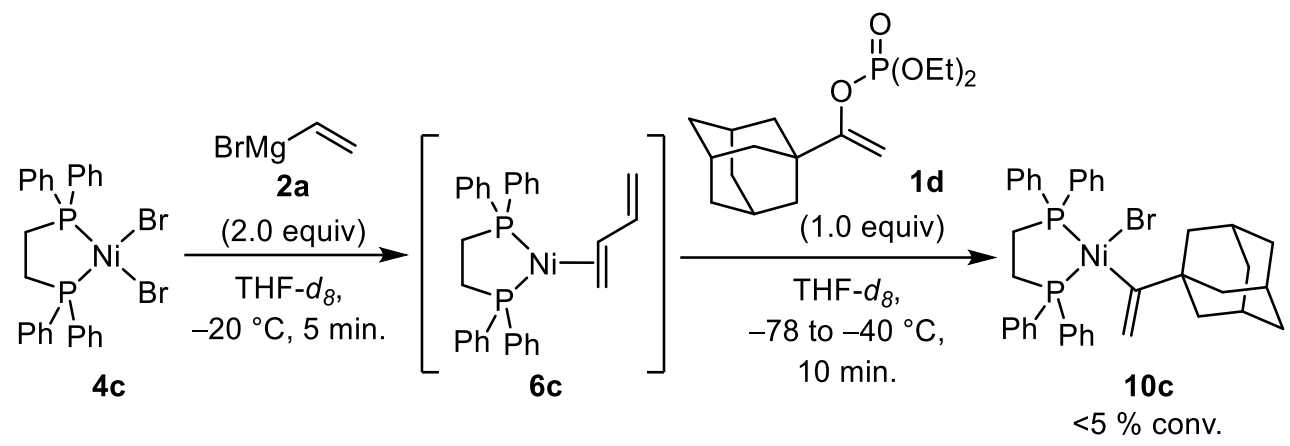

Figure S22.

Oxidative addition using 1d. In a $\mathrm{N}_{2}$-filled glovebox, [(dppe) $\left.\mathrm{NiBr}_{2}\right]$ 4c $(0.03 \mathrm{mmol}, 18.5 \mathrm{mg}$, 1.0 equiv) was charged in a $2 \mathrm{~mL}$ Schlenk, followed by a $155 \mathrm{mM}$ stock solution of 1,3-di-tertbutyl-2-methoxy-5-methylbenzene in THF- $d_{8}(7.8 \mu \mathrm{mol}, 50 \mu \mathrm{L})$ and THF- $\mathrm{d}_{8}(0.5 \mathrm{~mL}, 0.05 \mathrm{M}$ final concentration). The Schlenk was sealed, taken out of the glovebox, cooled to $-20{ }^{\circ} \mathrm{C}$, and a $0.8 \mathrm{M}$ solution of vinyl magnesium bromide $\mathbf{2 a}$ in was added $(0.06 \mathrm{mmol}, 75 \mu \mathrm{L}, 2.0$ equiv). The reaction mixture was stirred at $-20^{\circ} \mathrm{C}$ for 5 minutes. The deep red [(dppe)Ni(3g)] $6 \mathrm{c}$ solution was frozen in liquid nitrogen. To the frozen solution obtained was added a $0.6 \mathrm{M}$ 1-((3r,5r,7r)-adamantan-1-yl)vinyl diethyl phosphate 1d THF- $d_{8}$ solution $(0.03 \mathrm{mmol}, 50 \mu \mathrm{L}$, 1.0 equiv). The resulting mixture was thawed at $-78^{\circ} \mathrm{C}$ and left stirring for 10 minutes while warming up to $-40^{\circ} \mathrm{C}$. The solution was cooled to $-78^{\circ} \mathrm{C}$ and cannulated in a J-Young tube which was immediately analyzed by ${ }^{1} \mathrm{H}$ and ${ }^{31} \mathrm{P} \mathrm{NMR}$ at $-30{ }^{\circ} \mathrm{C}$. ${ }^{1} \mathrm{H}$ NMR indicated no conversion into the oxidative addition complex $10 \mathrm{c}$ and $18 \%$ consumption of enol phosphate $1 d$.

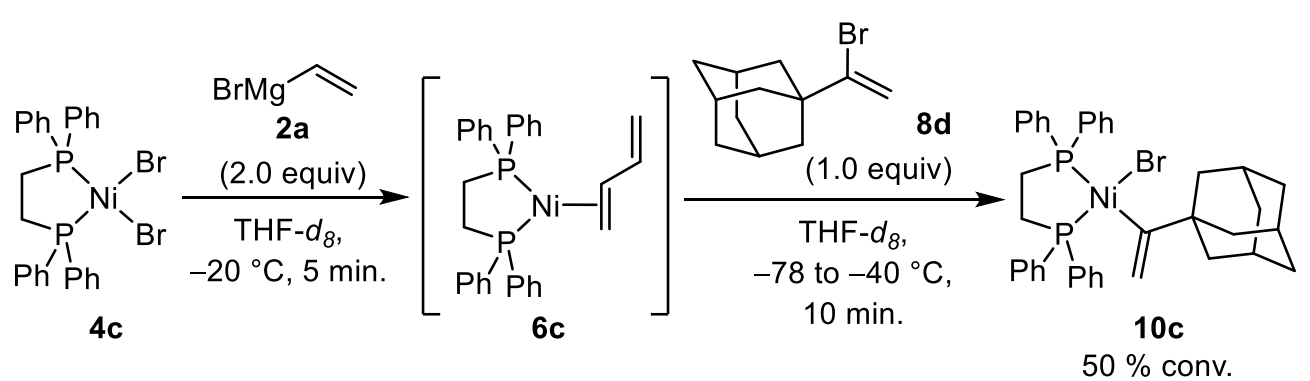

Figure S23.

Oxidative addition using $8 \mathrm{~d}$. In a $\mathrm{N}_{2}$-filled glovebox, [(dppe) $\left.\mathrm{NiBr}_{2}\right] \mathbf{4 c}(0.03 \mathrm{mmol}, 18.5 \mathrm{mg}$, 1.0 equiv) was charged in a $2 \mathrm{~mL}$ Schlenk, followed by a $178 \mathrm{mM}$ stock solution of 1,3-di-tertbutyl-2-methoxy-5-methylbenzene in THF- $d_{8}(8.9 \mu \mathrm{mol}, 50 \mu \mathrm{L})$ and THF- $d_{8}(0.5 \mathrm{~mL}, 0.05 \mathrm{M}$ final concentration). The Schlenk was sealed, taken out of the glovebox, cooled to $-20{ }^{\circ} \mathrm{C}$, and a $0.8 \mathrm{M}$ solution of vinyl magnesium bromide $2 \mathrm{a}$ in was added $(0.06 \mathrm{mmol}, 75 \mu \mathrm{L}, 2.0$ 
equiv). The reaction mixture was stirred at $-20^{\circ} \mathrm{C}$ for 5 minutes. The deep red [(dppe)Ni(3g)] $6 \mathbf{c}$ solution was frozen in liquid nitrogen. To the frozen solution obtained was added a $0.6 \mathrm{M}$ 1 -((3r,5r,7r)-adamantan-1-yl)vinyl bromide $8 d$ THF- $d_{8}$ solution $(0.03 \mathrm{mmol}, 50 \mu \mathrm{L}, 1.0$ equiv). The resulting mixture was thawed at $-78^{\circ} \mathrm{C}$ and left stirring for 10 minutes while warming up to $-40^{\circ} \mathrm{C}$. The solution was cooled to $-78^{\circ} \mathrm{C}$ and cannulated in a J-Young tube which was immediately analyzed by ${ }^{1} \mathrm{H}$ and ${ }^{31} \mathrm{P}$ NMR at $-30{ }^{\circ} \mathrm{C}$. ${ }^{1} \mathrm{H}$ NMR indicated $50 \%$ conversion into the oxidative addition complex $10 \mathrm{c}$ and $80 \%$ consumption of $1-((3 r, 5 r, 7 r)$-adamantan-1-yl)vinyl bromide $8 \mathbf{d}$. 


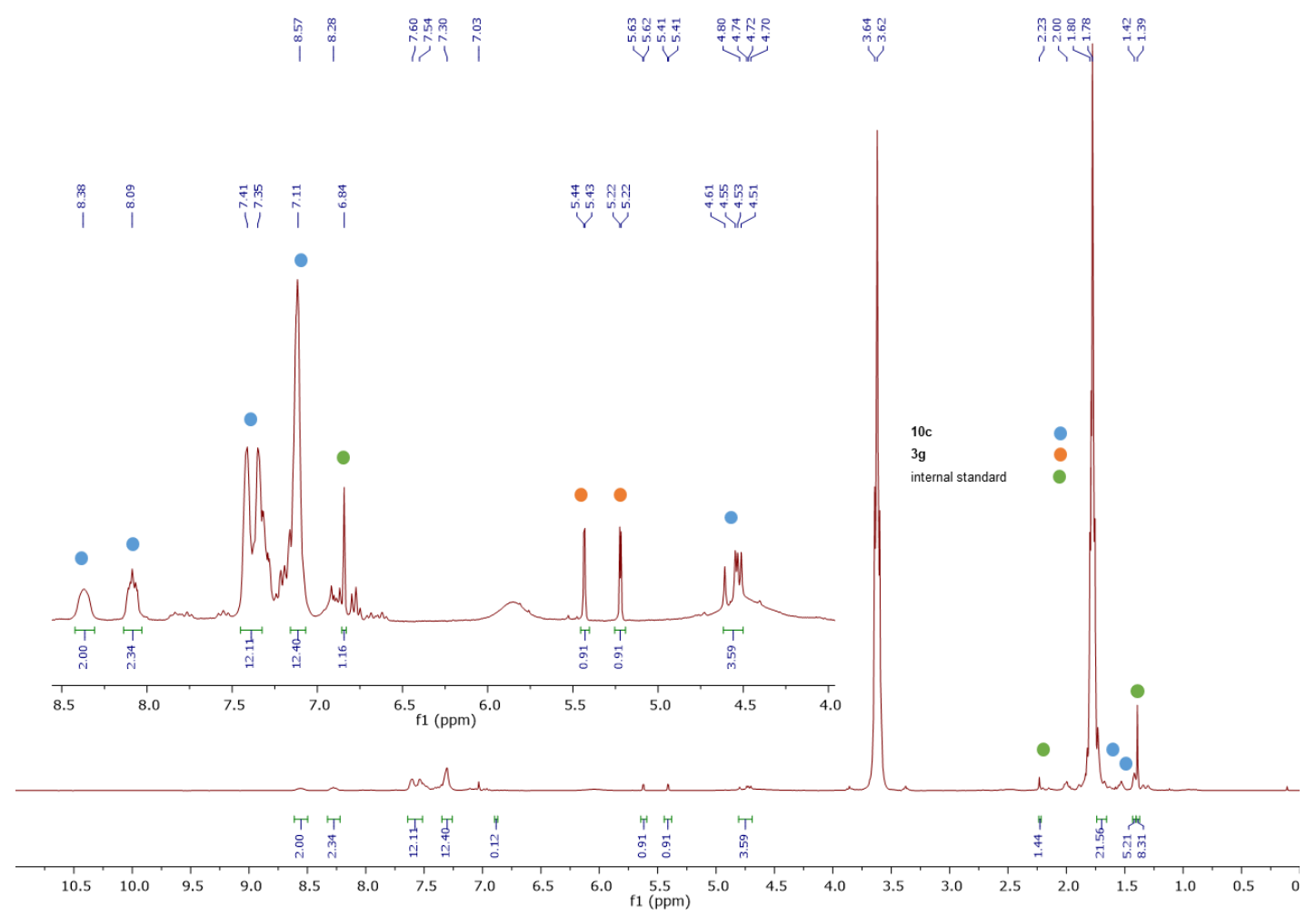

Figure S24. ${ }^{1} \mathrm{H}$ NMR $\left(300 \mathrm{MHz}, \mathrm{THF}-\mathrm{d}_{8}, 243 \mathrm{~K}\right)$ spectrum of the oxidative addition complex $10 \mathrm{c}$ starting from $\mathbf{8 d}$ and $\mathbf{4 c}$.

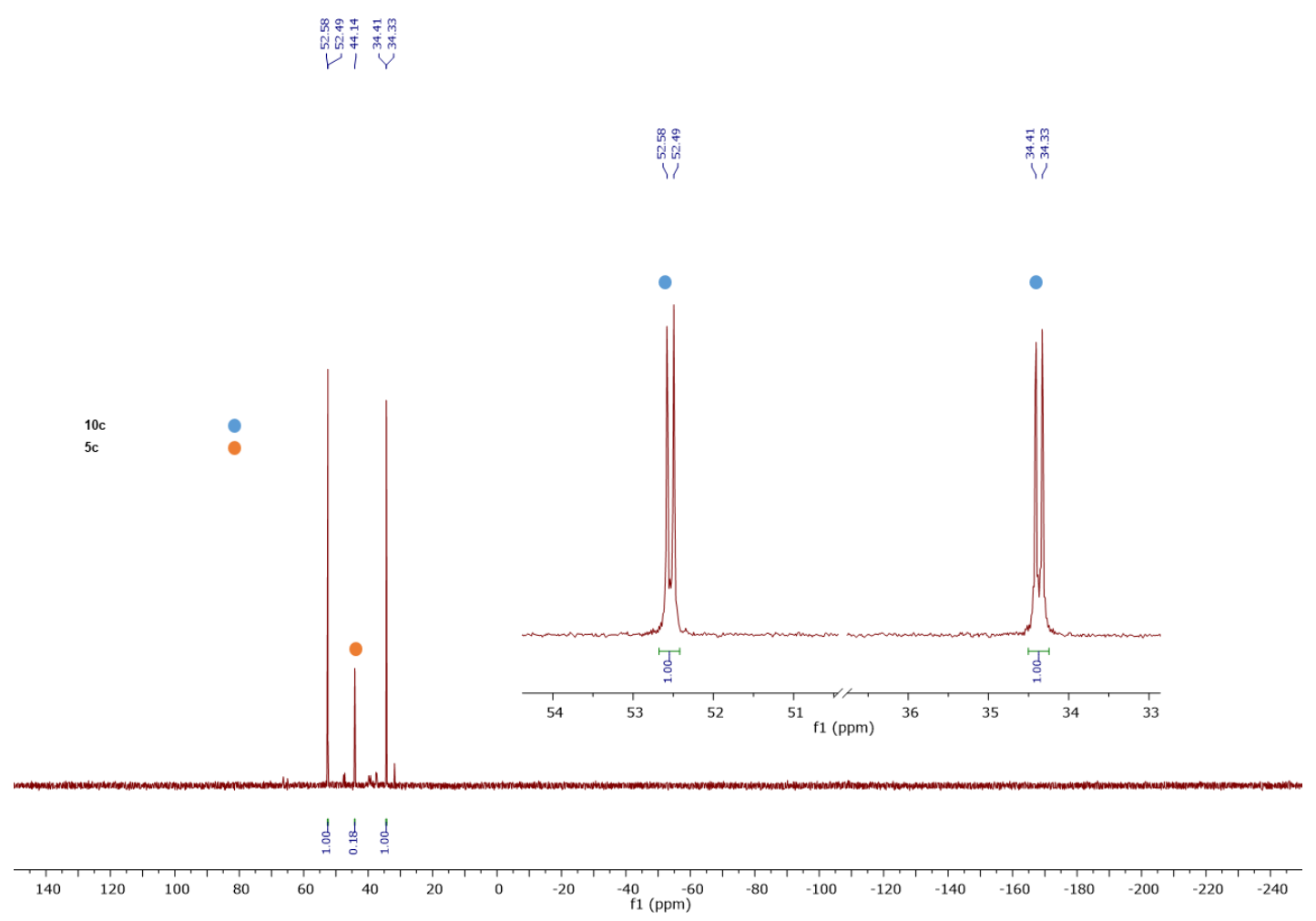

Figure S25. ${ }^{31} \mathrm{P}\left\{{ }^{1} \mathrm{H}\right\}$ NMR $\left(160 \mathrm{MHz}, \mathrm{THF}-\mathrm{d}_{8}, 243 \mathrm{~K}\right)$ spectrum of the oxidative addition complex 10c starting from $\mathbf{8 d}$ and $\mathbf{4 c}$. 


\subsection{Oxidative addition complexes $9 \mathrm{~d}$ and $10 \mathrm{~d}$}

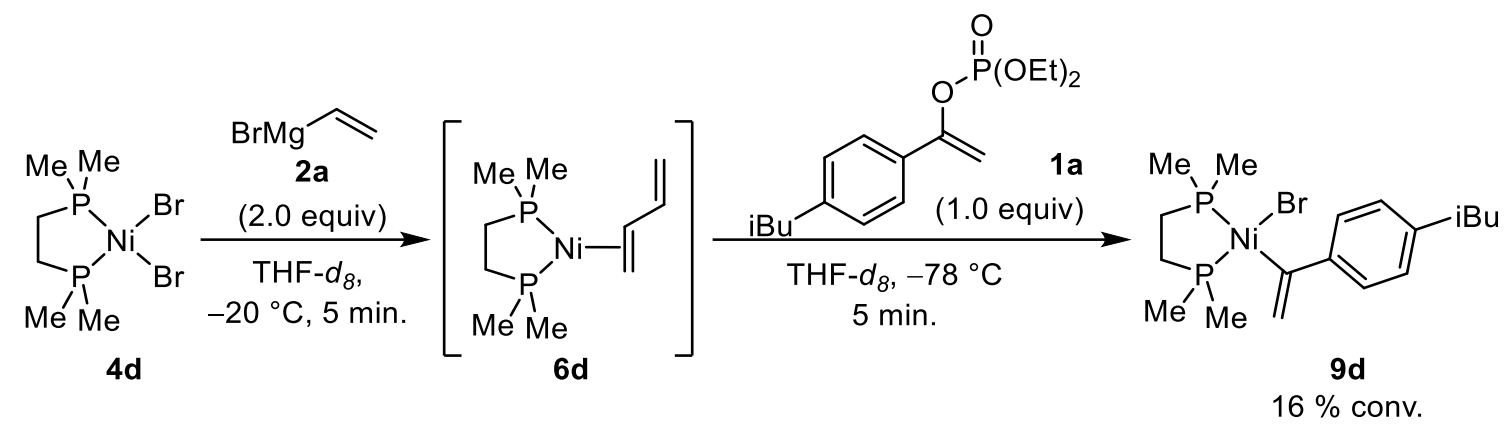

Figure S26.

Oxidative addition using 1a. In a $\mathrm{N}_{2}$-filled glovebox, [(dmpe) $\left.\mathrm{NiBr}_{2}\right]$ 4d (0.03 mmol, 11.06 $\mathrm{mg}, 1.0$ equiv) was charged in a $2 \mathrm{~mL}$ Schlenk, followed by a $166 \mathrm{mM}$ stock solution of 1,3-ditert-butyl-2-methoxy-5-methylbenzene in THF- $d_{8}(83 \mu \mathrm{mol}, 50 \mu \mathrm{L})$ and THF- $d_{8}(0.45 \mathrm{~mL}, 0.06$ M). The Schlenk was sealed, taken out of the glovebox, cooled to $-20{ }^{\circ} \mathrm{C}$, and a $0.85 \mathrm{M}$ solution of vinyl magnesium bromide $2 \mathbf{a}$ in THF was added ( $0.04 \mathrm{mmol}, 47 \mu \mathrm{L}, 2.0$ equiv). The reaction mixture was stirred at $-20^{\circ} \mathrm{C}$ for 5 minutes. The deep red $[(\mathrm{dmpe}) \mathrm{Ni}(\mathbf{3 g})] \mathbf{6 d}$ solution was frozen in liquid nitrogen. To the frozen solution obtained was added a 0.6 M diethyl (1-(4isobutylphenyl)vinyl) phosphate solution in THF- $d_{8}(0.03 \mathrm{mmol}, 50 \mu \mathrm{L}, 1.0$ equiv). The resulting brown suspension was stirred at $-78^{\circ} \mathrm{C}$ and the solution was cannulated in a J-Young tube which was immediately analyzed by ${ }^{1} \mathrm{H}$ and ${ }^{31} \mathrm{P}$ NMR at $-30{ }^{\circ} \mathrm{C} .{ }^{1} \mathrm{H}$ NMR indicated a $16 \%$ conversion into the oxidative addition complex $9 \mathrm{~d}$ and $80 \%$ consumption of diethyl (1-(4isobutylphenyl)vinyl) phosphate 1a. 


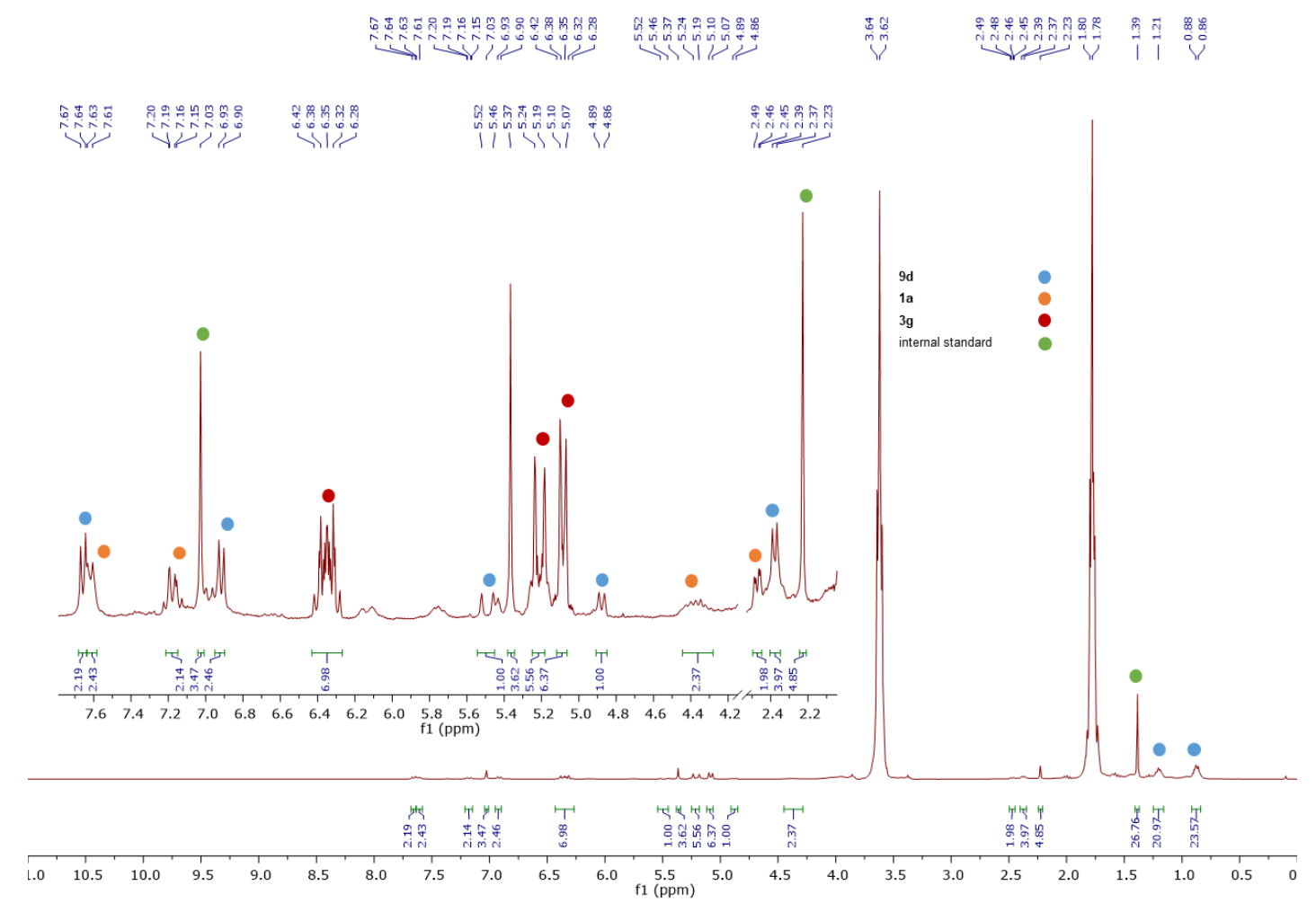

Figure S27. ${ }^{1} \mathrm{H}$ NMR $\left(300 \mathrm{MHz}, \mathrm{THF}-\mathrm{d}_{8}, 243 \mathrm{~K}\right)$ spectrum of the oxidative addition complex 9d starting from $1 \mathrm{a}$ and $\mathbf{4 d}$.

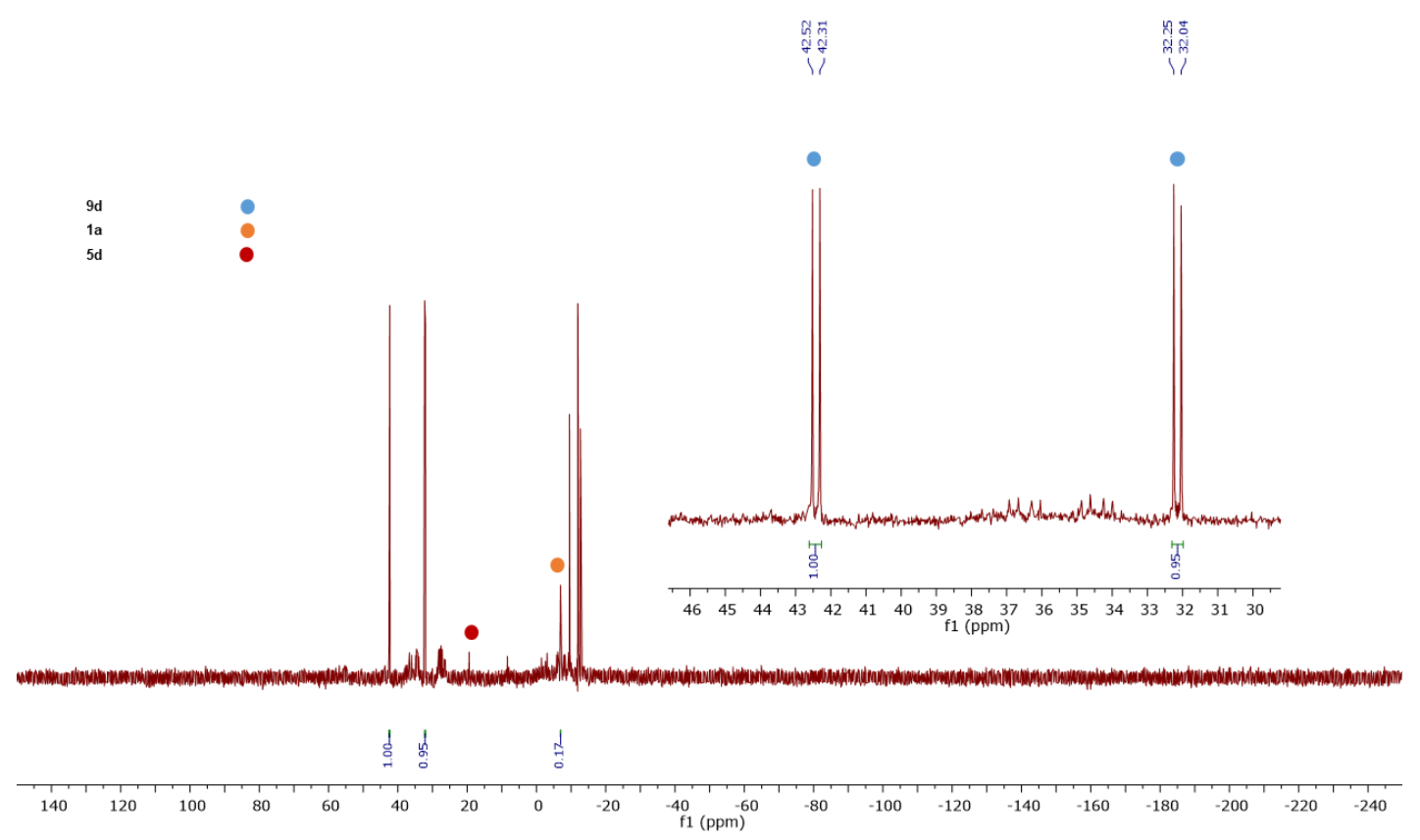

Figure S28. ${ }^{31} \mathrm{P}\left\{{ }^{1} \mathrm{H}\right\}$ NMR $\left(160 \mathrm{MHz}, \mathrm{THF}-\mathrm{d}_{8}, 243 \mathrm{~K}\right)$ spectrum of the oxidative addition complex $9 \mathrm{~d}$ starting from $\mathbf{1 a}$ and $\mathbf{4 d}$. 


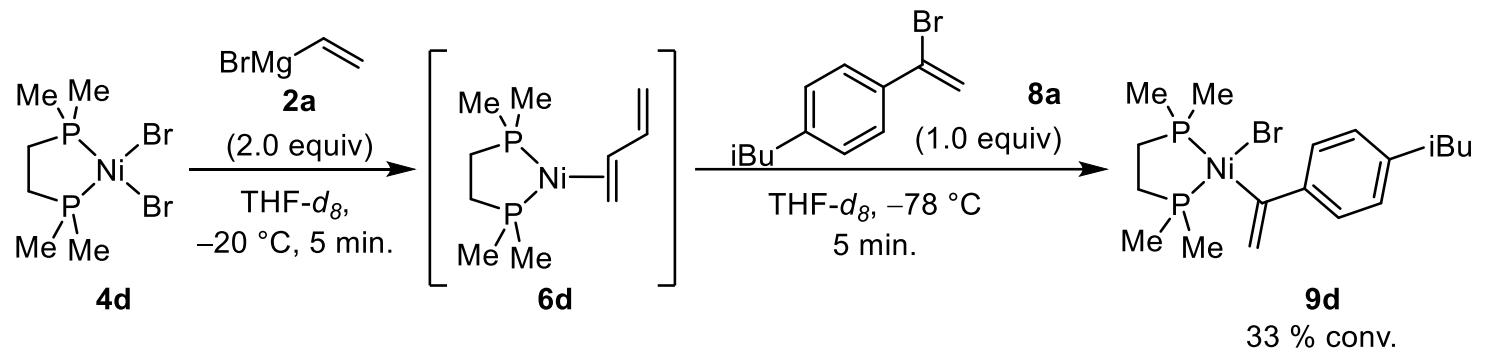

Figure S29.

Oxidative addition using 8a. In a $\mathrm{N}_{2}$-filled glovebox, [(dmpe) $\left.\mathrm{NiBr}_{2}\right](0.02 \mathrm{mmol}, 7.4 \mathrm{mg}, 1.0$ equiv) was charged in a $2 \mathrm{~mL}$ Schlenk, followed by a $277 \mathrm{mM}$ stock solution of 1,3-di-tertbutyl-2-methoxy-5-methylbenzene in THF- $d_{8}(13.9 \mu \mathrm{mol}, 50 \mu \mathrm{L})$ and THF- $d_{8}(0.45 \mathrm{~mL}, 0.04$ M). The Schlenk was sealed, taken out of the glovebox, cooled to $-20{ }^{\circ} \mathrm{C}$, and a $0.85 \mathrm{M}$ solution of vinyl magnesium bromide $2 \mathrm{a}$ was added ( $0.04 \mathrm{mmol}, 47 \mu \mathrm{L}, 2.0$ equiv). The reaction mixture was stirred at $-20^{\circ} \mathrm{C}$ for 20 minutes. The deep red $[(\mathrm{dmpe}) \mathrm{Ni}(\mathbf{3 g})] \mathbf{6 d}$ solution was frozen in liquid nitrogen. To the frozen solution obtained was added a $0.4 \mathrm{M}$ solution of 1 (1-bromovinyl)-4-isobutylbenzene in THF- $d_{8}(0.02 \mathrm{mmol}, 50 \mu \mathrm{L}, 1.0$ equiv). The resulting brown mixture was stirred at $-78{ }^{\circ} \mathrm{C}$ for 5 minutes and the solution was cannulated in a $\mathrm{J}$ Young tube which was immediately analyzed by ${ }^{1} \mathrm{H}$ and ${ }^{31} \mathrm{P}$ NMR at $-30{ }^{\circ} \mathrm{C}$. ${ }^{1} \mathrm{H}$ NMR indicated a $33 \%$ conversion into the oxidative addition complex $9 \mathrm{~d}$ and $89 \%$ consumption of 1-(1bromovinyl)-4-isobutylbenzene $\mathbf{8 a}$. 


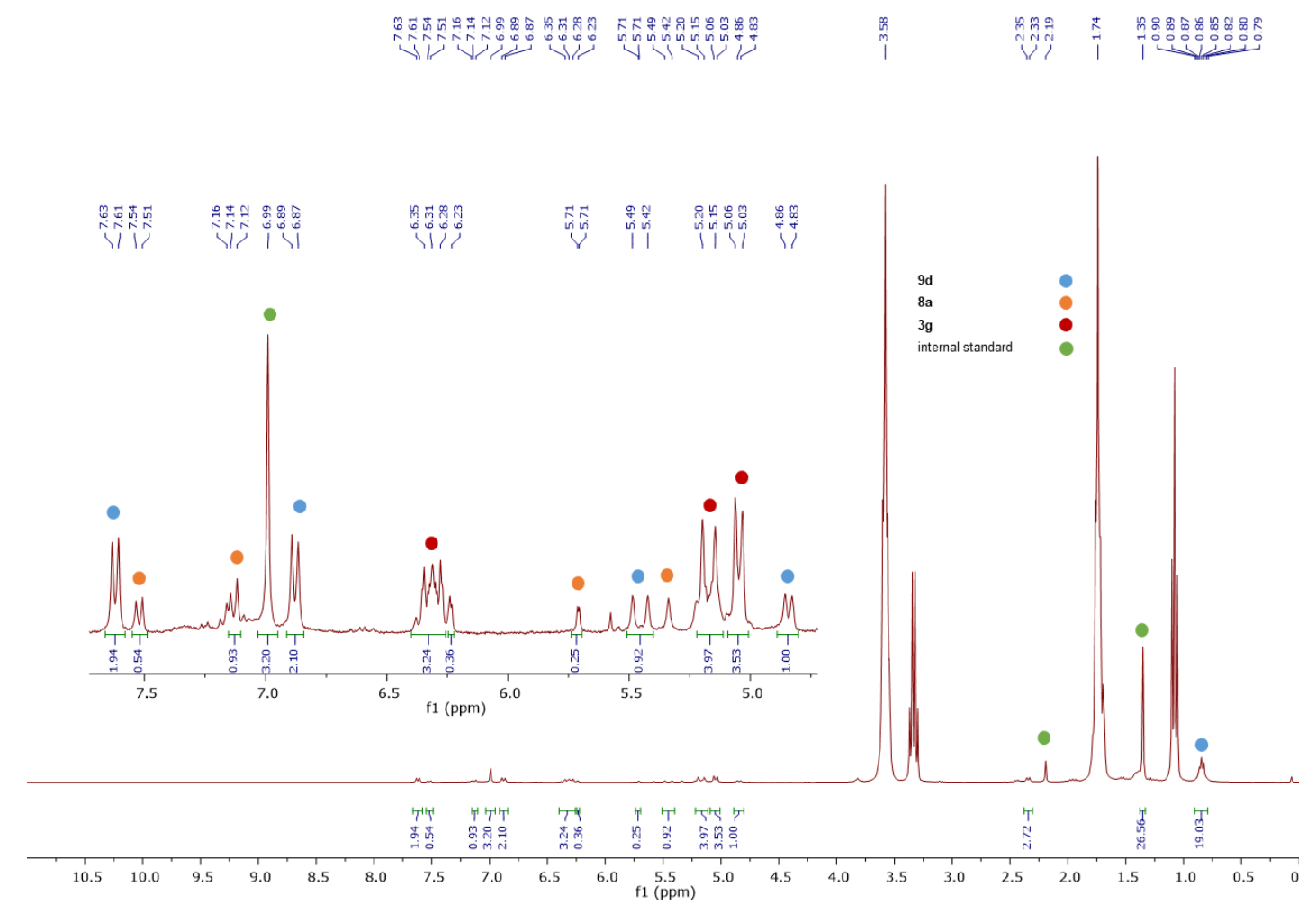

Figure S30. ${ }^{1} \mathrm{H}$ NMR $\left(300 \mathrm{MHz}, \mathrm{THF}-\mathrm{d}_{8}, 243 \mathrm{~K}\right)$ spectrum of the oxidative addition complex 9d starting from $\mathbf{8 a}$ and $\mathbf{4 d}$.

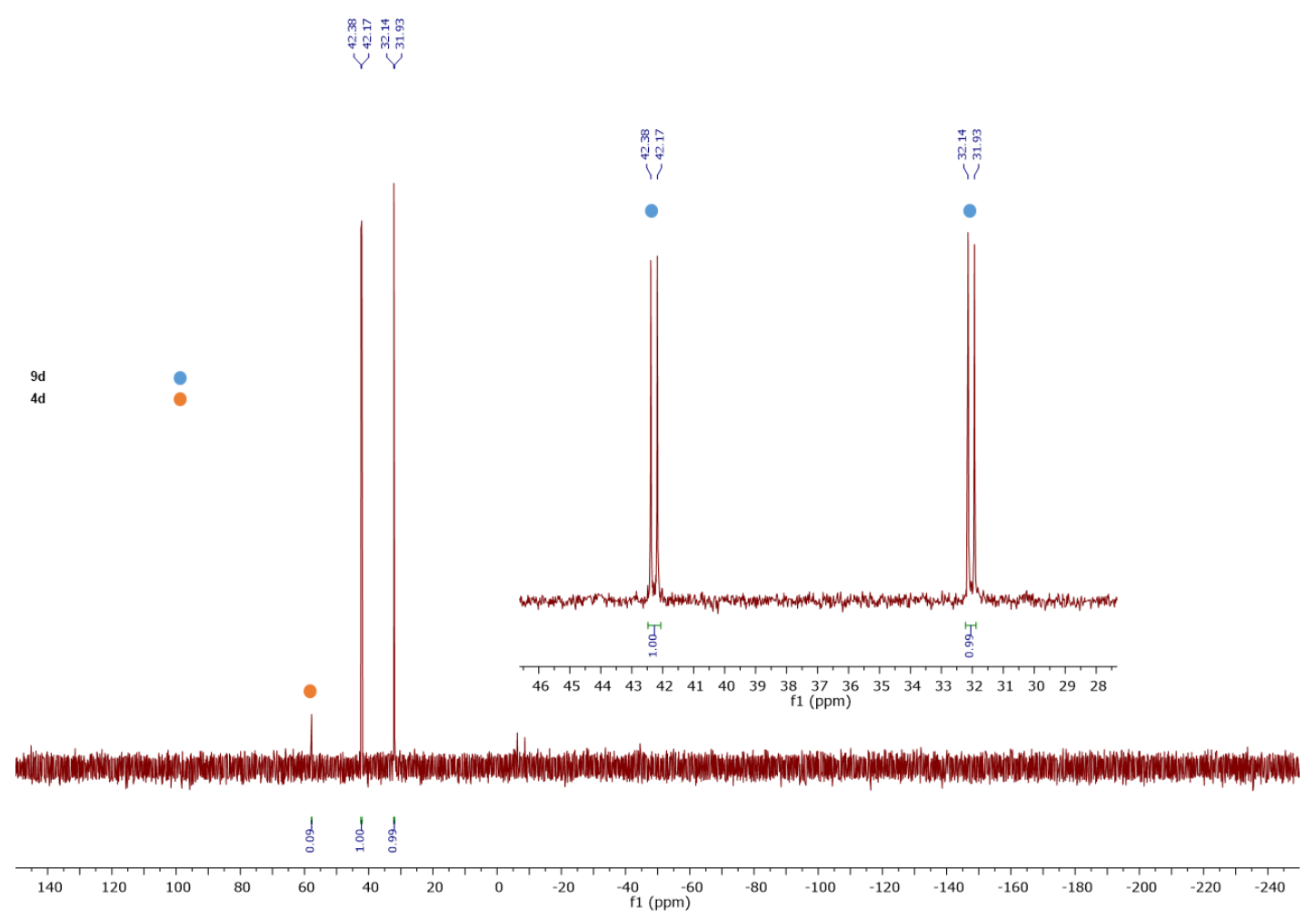

Figure S31. ${ }^{31} \mathrm{P}\left\{{ }^{1} \mathrm{H}\right\}$ NMR $\left(160 \mathrm{MHz}, \mathrm{THF}-\mathrm{d}_{8}, 243 \mathrm{~K}\right)$ spectrum of the oxidative addition complex $9 \mathbf{d}$ starting from $\mathbf{8 a}$ and $\mathbf{4 d}$. 


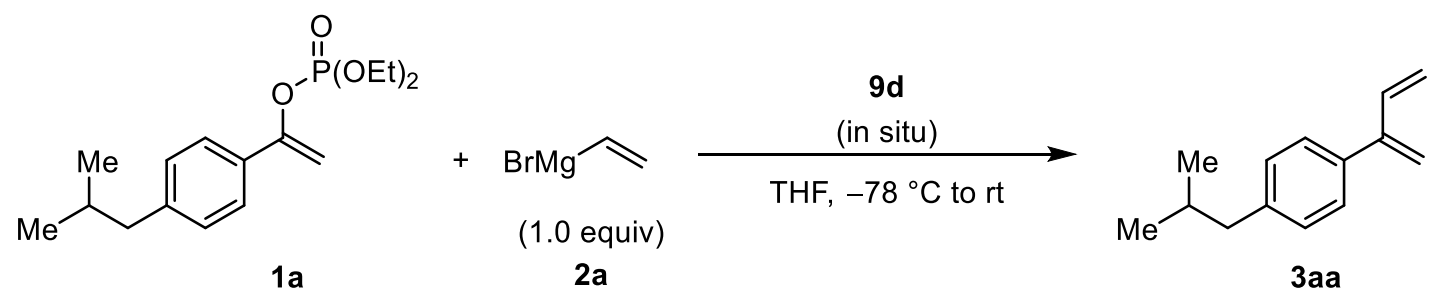

Figure S32.

Catalytic relevance of in situ generated 9d. In a $\mathrm{N}_{2}$-filled glovebox, [(dmpe) $\left.\mathrm{NiBr}_{2}\right] \mathbf{4 d}(0.015$ mmol, $5.5 \mathrm{mg}, 2.5 \mathrm{~mol} \%$ ) was charged in a $5 \mathrm{~mL}$ Schlenk, followed by THF (1.56 mL, $0.25 \mathrm{M}$ final concentration). The Schlenk was sealed, taken out of the glovebox, cooled to $-20{ }^{\circ} \mathrm{C}$, and a $0.80 \mathrm{M}$ solution of vinyl magnesium bromide $2 \mathrm{a}$ in THF was added $(0.03 \mathrm{mmol}, 38 \mu \mathrm{L}$, $5 \mathrm{~mol} \%$ ). The reaction mixture was stirred at $-20^{\circ} \mathrm{C}$ for 5 minutes, then a $0.2 \mathrm{M}$ stock solution of 1-(1-bromovinyl)-4-isobutylbenzene $8 \mathrm{a}$ in THF $(0.015 \mathrm{mmol}, 50 \mu \mathrm{L}, 2.5 \mathrm{~mol} \%)$ was added. The resulting brown suspension was stirred at $-20{ }^{\circ} \mathrm{C}$ for $10 \mathrm{~min}$ before being cooled to -78 ${ }^{\circ} \mathrm{C}$. To the cooled mixture were added at the same time diethyl (1-(4-isobutylphenyl)vinyl) phosphate $1 \mathrm{a}(0.6 \mathrm{mmol}, 187 \mathrm{mg}, 1$ equiv) and a $0.80 \mathrm{M}$ solution of vinyl magnesium bromide 2a in THF (0.6 mmol, $750 \mu \mathrm{L}, 1$ equiv). The Schlenk was then removed from the cold bath and the reaction mixture was stirred at room temperature for 1 hour. The reaction was quenched by addition of $5.0 \mathrm{~mL}$ of a saturated solution of ammonium chloride at $0{ }^{\circ} \mathrm{C}$ and extracted with ethyl acetate $(3 \times 25 \mathrm{~mL})$. The organic layers were combined, dried over sodium sulfate, filtered and the solvent removed under vacuum. The crude residue was immediately analyzed by ${ }^{1} \mathrm{H}$ NMR with an internal standard (1,3-di-tert-butyl-2-methoxy-5-methylbenzene). ${ }^{1} \mathrm{H}$ NMR indicated a $76 \%$ conversion into diene 3 and $>95 \%$ consumption of diethyl (1-(4isobutylphenyl)vinyl) phosphate $\mathbf{1 a}$.

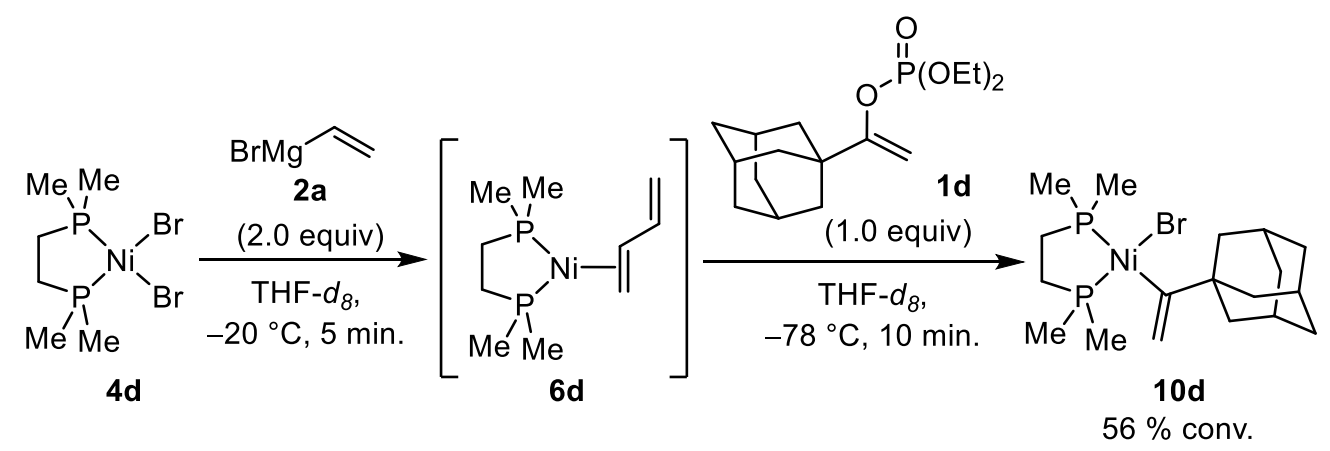

Figure S33.

Oxidative addition using 1d. In a $\mathrm{N}_{2}$-filled glovebox, [(dmpe) $\left.\mathrm{NiBr}_{2}\right] \mathbf{4 d}(0.03 \mathrm{mmol}, 11.06 \mathrm{mg}$, 1.0 equiv) was charged in a $2 \mathrm{~mL}$ Schlenk, followed by a $171 \mathrm{mM}$ stock solution of 1,3-di-tert- 
butyl-2-methoxy-5-methylbenzene in THF- $d_{8}(8.55 \mu \mathrm{mol}, 50 \mu \mathrm{L})$ and THF- $d_{8}(0.5 \mathrm{~mL}, 0.055$ M). The Schlenk was sealed, taken out of the glovebox, cooled to $-20{ }^{\circ} \mathrm{C}$, and a $0.82 \mathrm{M}$ solution of vinyl magnesium bromide $2 \mathrm{a}$ in was added $(0.06 \mathrm{mmol}, 73 \mu \mathrm{L}, 2.0$ equiv). The reaction mixture was stirred at $-20^{\circ} \mathrm{C}$ for 5 minutes. The deep red $[(\mathrm{dmpe}) \mathrm{Ni}(\mathbf{3 g})] \mathbf{6 d}$ solution was frozen in liquid nitrogen. To the frozen solution obtained was added a $0.6 \mathrm{M} \mathrm{1-((3r,5r,7r)-}$ adamantan-1-yl)vinyl diethyl phosphate $1 \mathrm{~d}$ THF- $d_{8}$ solution $(0.03 \mathrm{mmol}, 50 \mu \mathrm{L}, 1.0$ equiv). The resulting mixture was thawed at $-78^{\circ} \mathrm{C}$ and left stirring for 10 minutes at that temperature. The solution was cannulated in a J-Young tube which was immediately analyzed by ${ }^{1} \mathrm{H}$ and ${ }^{31} \mathrm{P}$ NMR at $-30{ }^{\circ} \mathrm{C} .{ }^{1} \mathrm{H}$ NMR indicated a $56 \%$ conversion into the oxidative addition complex $\mathbf{1 0 d}$ and full consumption of the 1-((3r,5r,7r)-adamantan-1-yl)vinyl diethyl phosphate $\mathbf{1 d}$. 


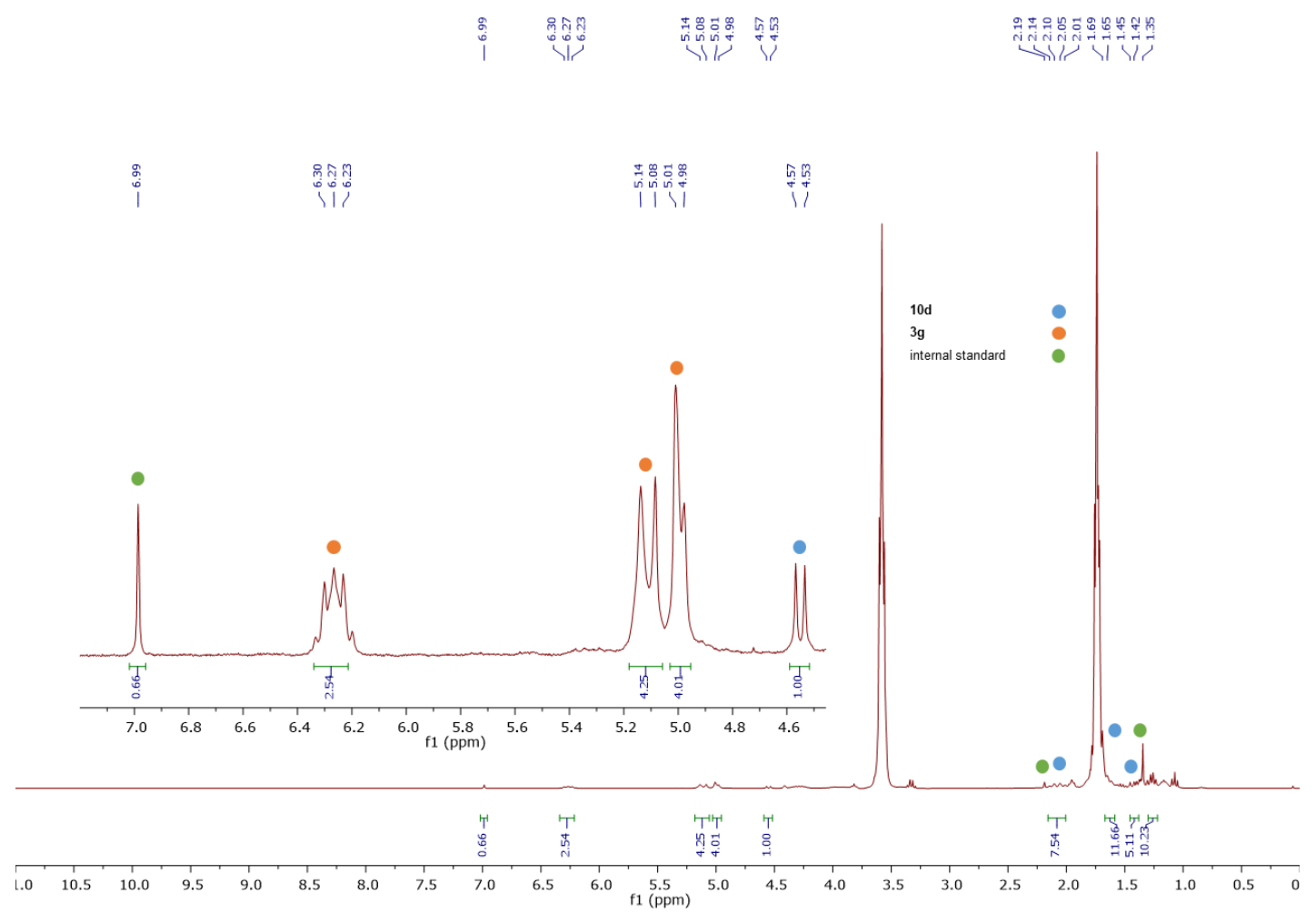

Figure S34. ${ }^{1} \mathrm{H}$ NMR $\left(300 \mathrm{MHz}, \mathrm{THF}-\mathrm{d}_{8}, 243 \mathrm{~K}\right)$ spectrum of the oxidative addition complex 10d starting from $1 \mathrm{~d}$ and $\mathbf{4 d}$.

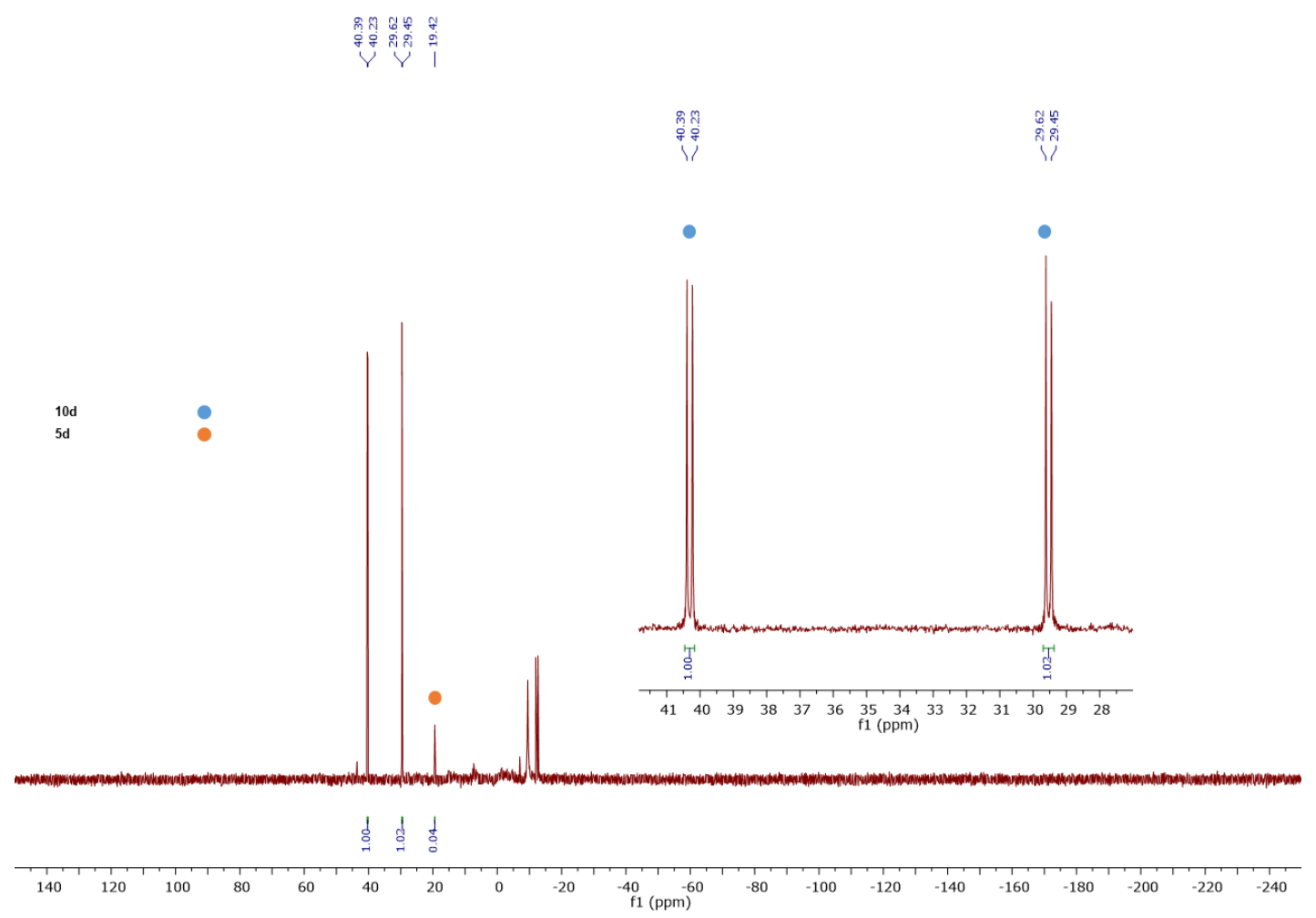

Figure S35. ${ }^{31} \mathrm{P}\left\{{ }^{1} \mathrm{H}\right\}$ NMR $\left(160 \mathrm{MHz}, \mathrm{THF}-d_{8}, 243 \mathrm{~K}\right)$ spectrum of the oxidative addition complex $\mathbf{1 0 d}$ starting from $\mathbf{1 d}$ and $\mathbf{4 d}$. 


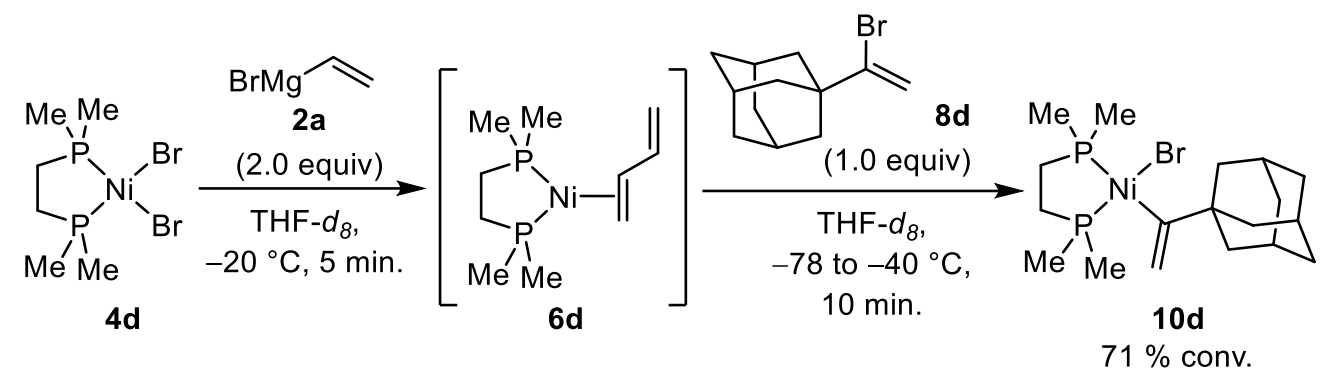

Figure S36.

Oxidative addition using $8 \mathrm{~d}$. In a $\mathrm{N}_{2}$-filled glovebox, [(dmpe) $\left.\mathrm{NiBr}_{2}\right] \mathbf{4 d}(0.02 \mathrm{mmol}, 7.4 \mathrm{mg}$, 1.0 equiv) was charged in a $2 \mathrm{~mL}$ Schlenk, followed by a $277 \mathrm{mM}$ stock solution of 1,3-di-tertbutyl-2-methoxy-5-methylbenzene in THF- $d_{8}(14 \mu \mathrm{mol}, 50 \mu \mathrm{L})$ and THF $(0.45 \mathrm{~mL}, 0.04 \mathrm{M})$. The Schlenk was sealed, taken out of the glovebox, cooled to $-20^{\circ} \mathrm{C}$, and a $0.85 \mathrm{M}$ solution of vinyl magnesium bromide $2 \mathrm{a}$ in was added $(0.04 \mathrm{mmol}, 47 \mu \mathrm{L}, 2.0$ equiv). The reaction mixture was stirred at $-20^{\circ} \mathrm{C}$ for 5 minutes. The deep red [(dmpe)Ni(3g)] $6 \mathbf{d}$ solution was frozen in liquid nitrogen. To the frozen solution obtained was added a 1-((3r,5r,7r)-adamantan1-yl)vinyl bromide $8 d 0.4 \mathrm{M} \mathrm{THF}-d_{8}$ solution $(0.04 \mathrm{mmol}, 100 \mu \mathrm{L}, 2.0$ equiv). The resulting mixture was thawed at $-78{ }^{\circ} \mathrm{C}$ and left stirring for 10 minutes while warming to $-40{ }^{\circ} \mathrm{C}$. The solution was cannulated in a $\mathrm{J}$-Young tube which was immediately analyzed by ${ }^{1} \mathrm{H}$ and ${ }^{31} \mathrm{P}$ NMR at $-30{ }^{\circ} \mathrm{C} .{ }^{1} \mathrm{H}$ NMR indicated a $71 \%$ conversion into the oxidative addition complex $10 \mathrm{~d}$ and $43 \%$ consumption of $1-((3 r, 5 r, 7 r)$-adamantan-1-yl)vinyl bromide $\mathbf{8 d}$. 


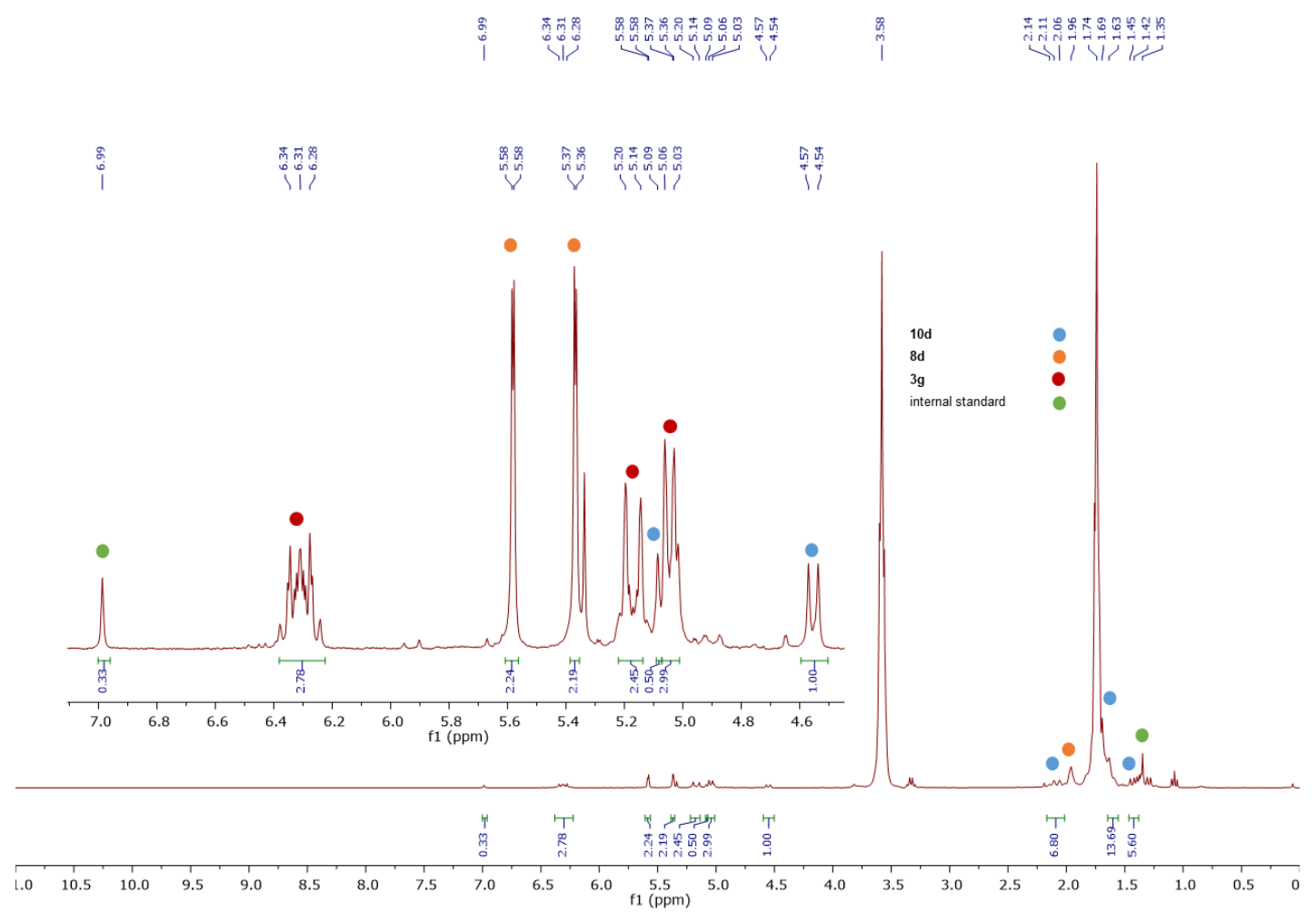

Figure S37. ${ }^{1} \mathrm{H}$ NMR $\left(300 \mathrm{MHz}, \mathrm{THF}-\mathrm{d}_{8}, 243 \mathrm{~K}\right)$ spectrum of the oxidative addition complex 10d starting from $\mathbf{8 d}$ and $\mathbf{4 d}$.

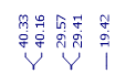

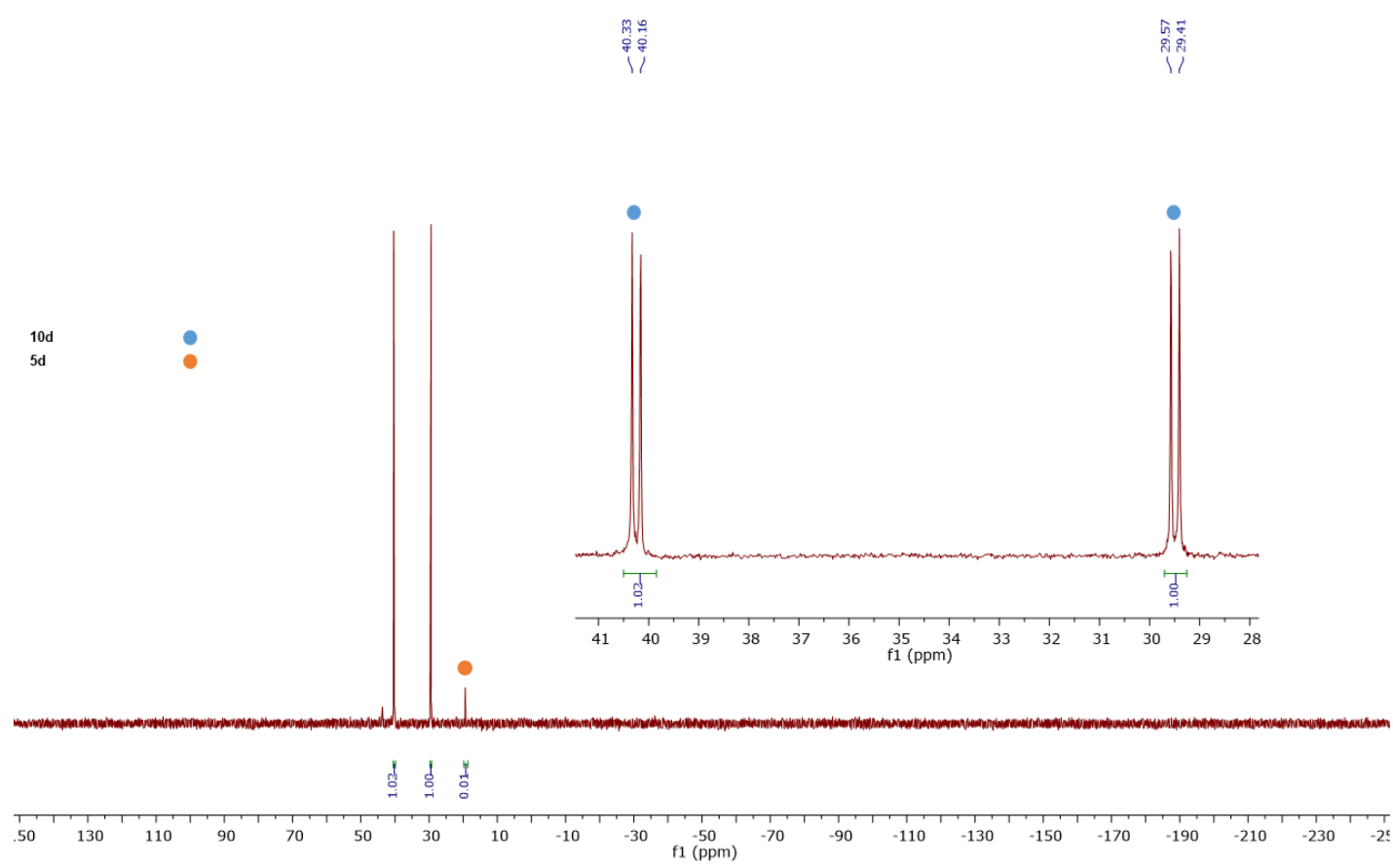

Figure S38. ${ }^{31} \mathrm{P}\left\{{ }^{1} \mathrm{H}\right\}$ NMR $\left(160 \mathrm{MHz}, \mathrm{THF}-\mathrm{d}_{8}, 243 \mathrm{~K}\right)$ spectrum of the oxidative addition complex $\mathbf{1 0 d}$ starting from $\mathbf{8 d}$ and $\mathbf{4 d}$. 


\section{Transmetalation/Reductive elimination}

\subsection{Transmetalation/Reductive elimination on 9c}

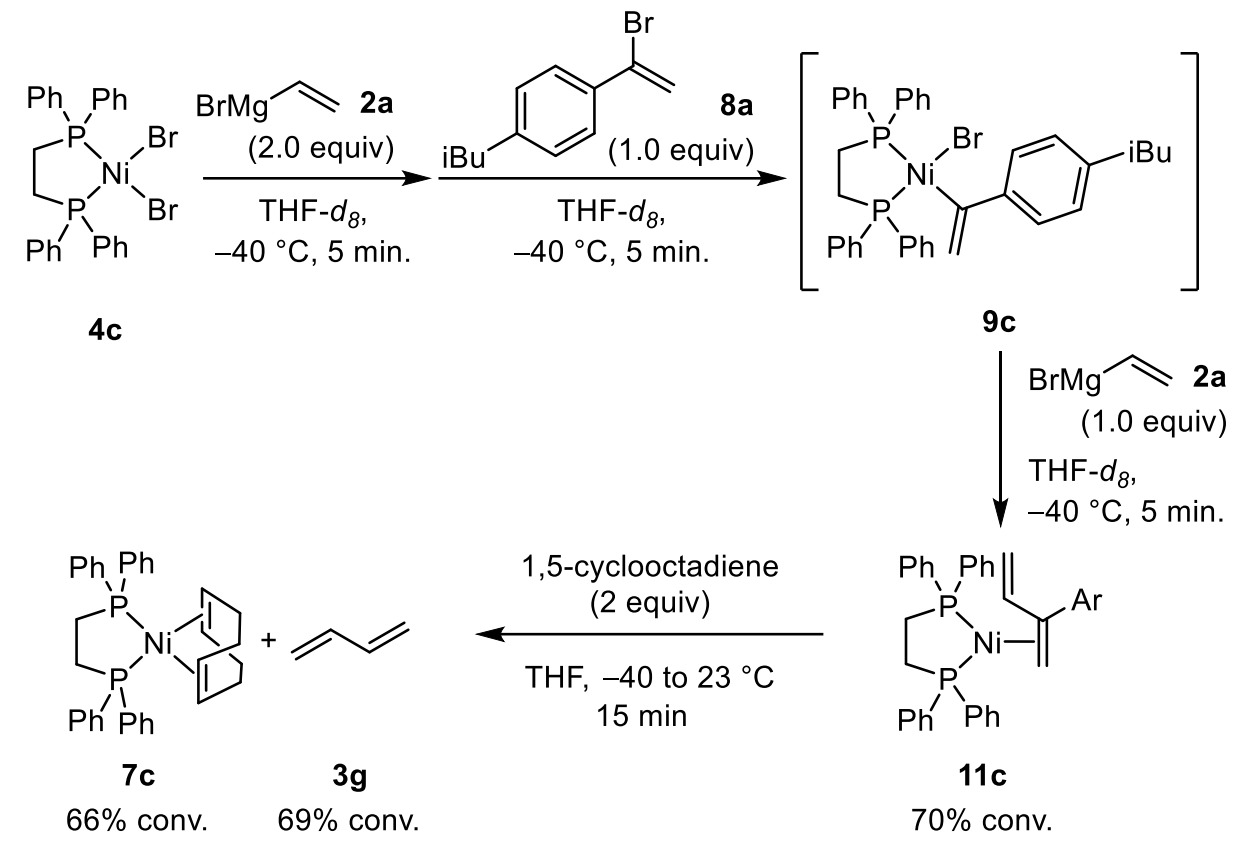

Figure S39.

In a $\mathrm{N}_{2}$-filled glovebox, [(dppe) $\mathrm{NiBr}_{2}$ ] $4 \mathrm{c}(0.02 \mathrm{mmol}, 12.3 \mathrm{mg}, 1.0$ equiv) was charged in a 5 $\mathrm{mL}$ Schlenk, followed by a $91.3 \mathrm{mM}$ stock solution of 1,3-di-tert-butyl-2-methoxy-5methylbenzene in THF- $d_{8}(2.28 \mu \mathrm{mol}, 25 \mu \mathrm{L}, 0.11$ equiv) and THF (1.0 mL, $0.02 \mathrm{M})$. The Schlenk was sealed, taken out of the glovebox, cooled to $-40{ }^{\circ} \mathrm{C}$, and a $0.90 \mathrm{M}$ solution of vinyl magnesium bromide $2 \mathrm{a}$ in THF was added $(0.04 \mathrm{mmol}, 44 \mu \mathrm{L}, 2.0$ equiv). The reaction mixture was stirred at $-40^{\circ} \mathrm{C}$ for 5 minutes, then a $0.2 \mathrm{M}$ stock solution of 1-(1-bromovinyl)-4isobutylbenzene in THF (0.02 mmol, $100 \mu \mathrm{L}, 1.0$ equiv) was added. The resulting black suspension was stirred at $-40^{\circ} \mathrm{C}$ for 10 minutes, then a $0.90 \mathrm{M}$ solution of vinyl magnesium bromide $2 \mathrm{a}$ in THF was added $(0.02 \mathrm{mmol}, 22 \mu \mathrm{L}, 1.0$ equiv). The resulting dark red reaction mixture was stirred for 5 minutes at $-40{ }^{\circ} \mathrm{C}$, then concentrated in vacuum at $-40{ }^{\circ} \mathrm{C}$. The residual brown oil was dissolved in THF- $d_{8}(1.0 \mathrm{~mL})$, the resulting solution was frozen in liquid nitrogen, the Schlenk was rapidly introduced in a $\mathrm{N}_{2}$-filled glovebox, and the solution was transferred in a J-Young tube which was immediately analyzed by ${ }^{1} \mathrm{H}$ and ${ }^{31} \mathrm{P}$ NMR at $-30{ }^{\circ} \mathrm{C}$. ${ }^{1} \mathrm{H}$ NMR indicated a $70 \%$ conversion into the diene complex 11c. Neat 1,5-cyclooctadiene ( $0.02 \mathrm{mmol}, 2.5 \mu \mathrm{L}$, ca. 1.0 equiv) was then added to the tube, the resulting solution was allowed to warm to room temperature and analyzed by ${ }^{1} \mathrm{H}$ and ${ }^{31} \mathrm{P}$ NMR at room temperature. ${ }^{1} \mathrm{H}$ NMR indicated a $66 \%$ conversion into [(dppe) Ni(cod)] 7c and a $69 \%$ conversion to free 1-(buta-1,3-dien-2-yl)-4-isobutylbenzene 3aa. 


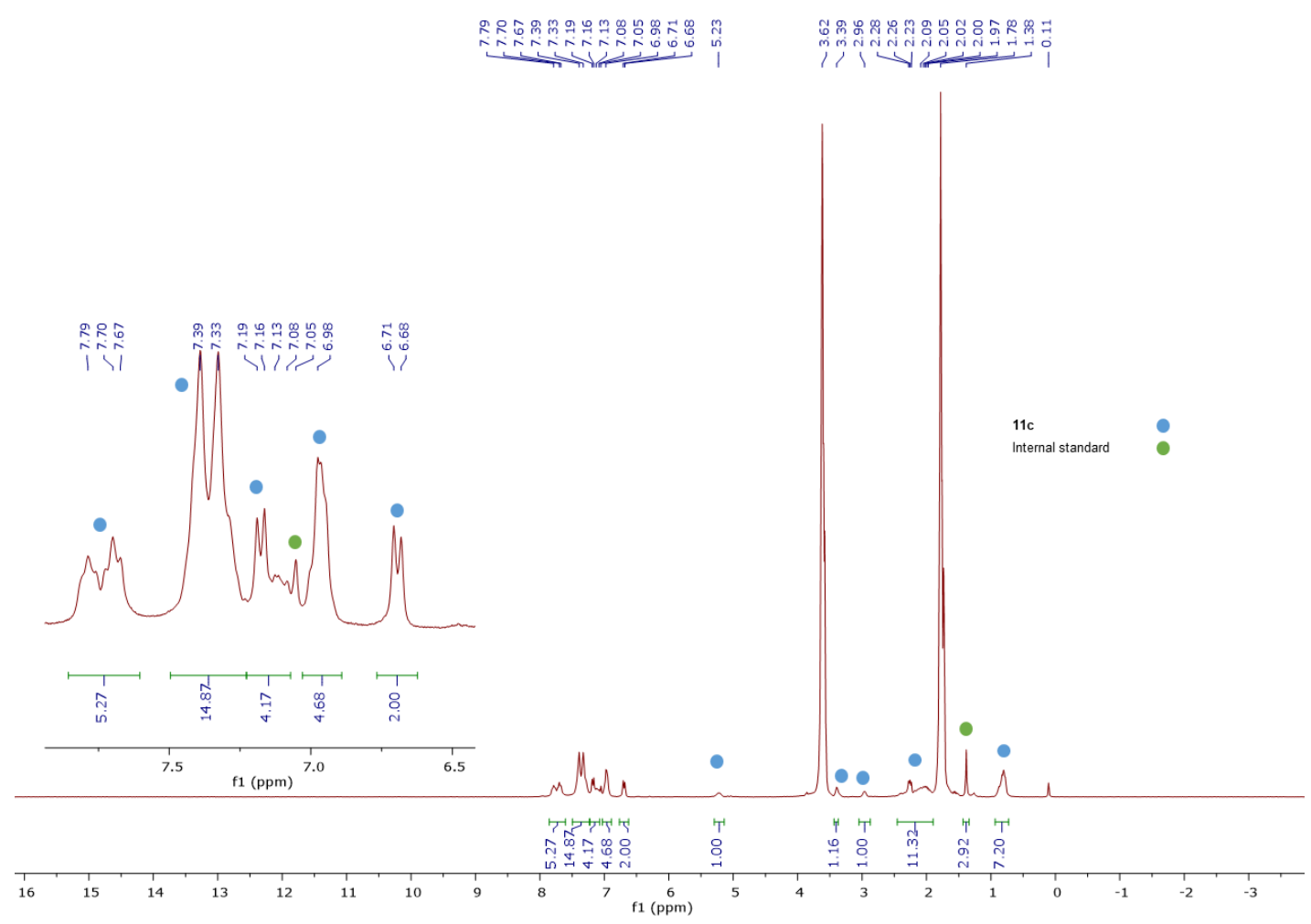

Figure S40. ${ }^{1} \mathrm{H}$ NMR $\left(300 \mathrm{MHz}, \mathrm{THF}-d_{8}, 243 \mathrm{~K}\right)$ spectrum of the transmetalation/reductive elimination on $9 \mathbf{c}$.

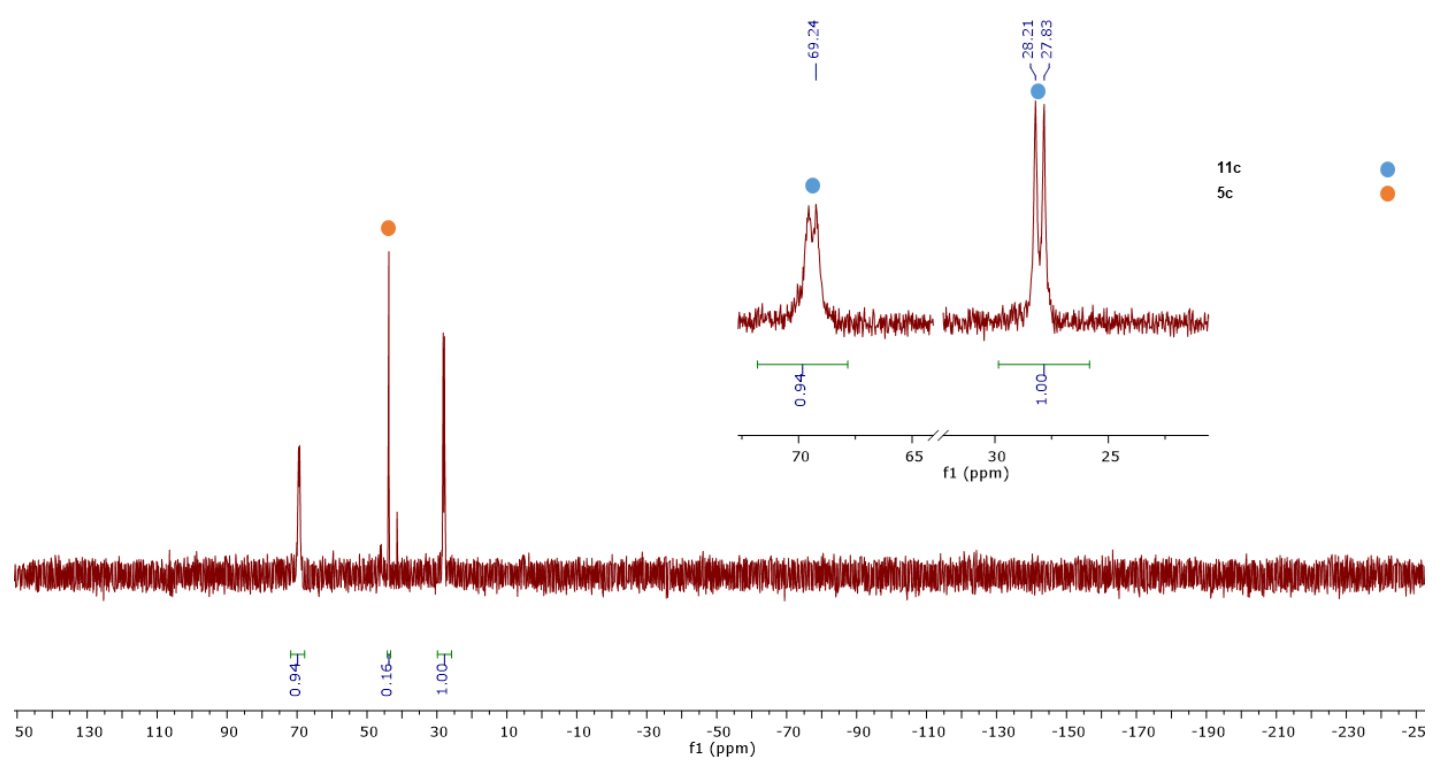

Figure S41. ${ }^{31} \mathrm{P}\left\{{ }^{1} \mathrm{H}\right\} \mathrm{NMR}\left(160 \mathrm{MHz}, \mathrm{THF}-\mathrm{d}_{8}, 243 \mathrm{~K}\right)$ spectrum of the transmetalation/reductive elimination on $\mathbf{9 c}$. 


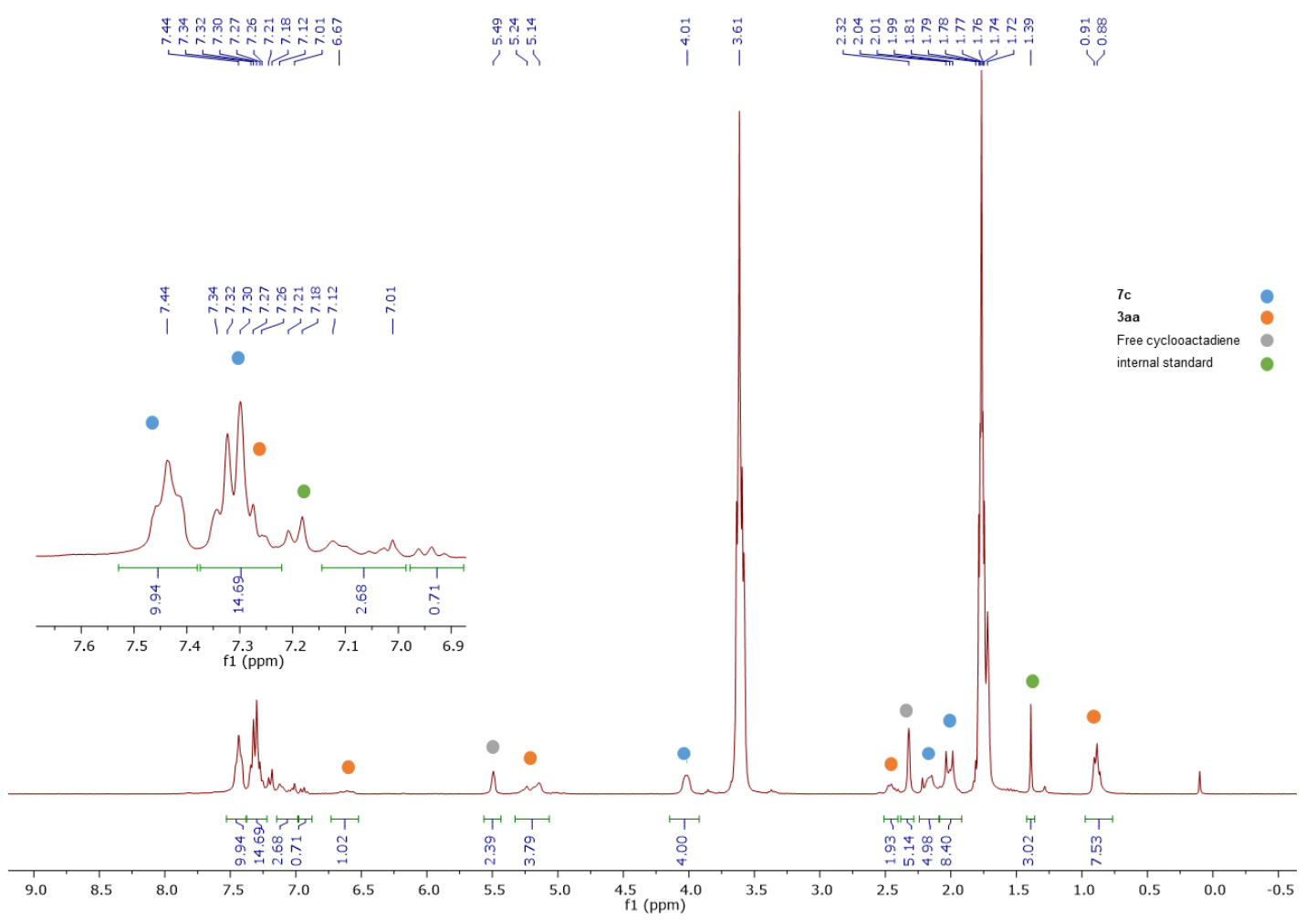

Figure S42. ${ }^{1} \mathrm{H}$ NMR $\left(300 \mathrm{MHz}, \mathrm{THF}-d_{8}, 298 \mathrm{~K}\right)$ spectrum of the transmetalation/reductive elimination on $\mathbf{9 c}$ after cyclooctadiene addition.

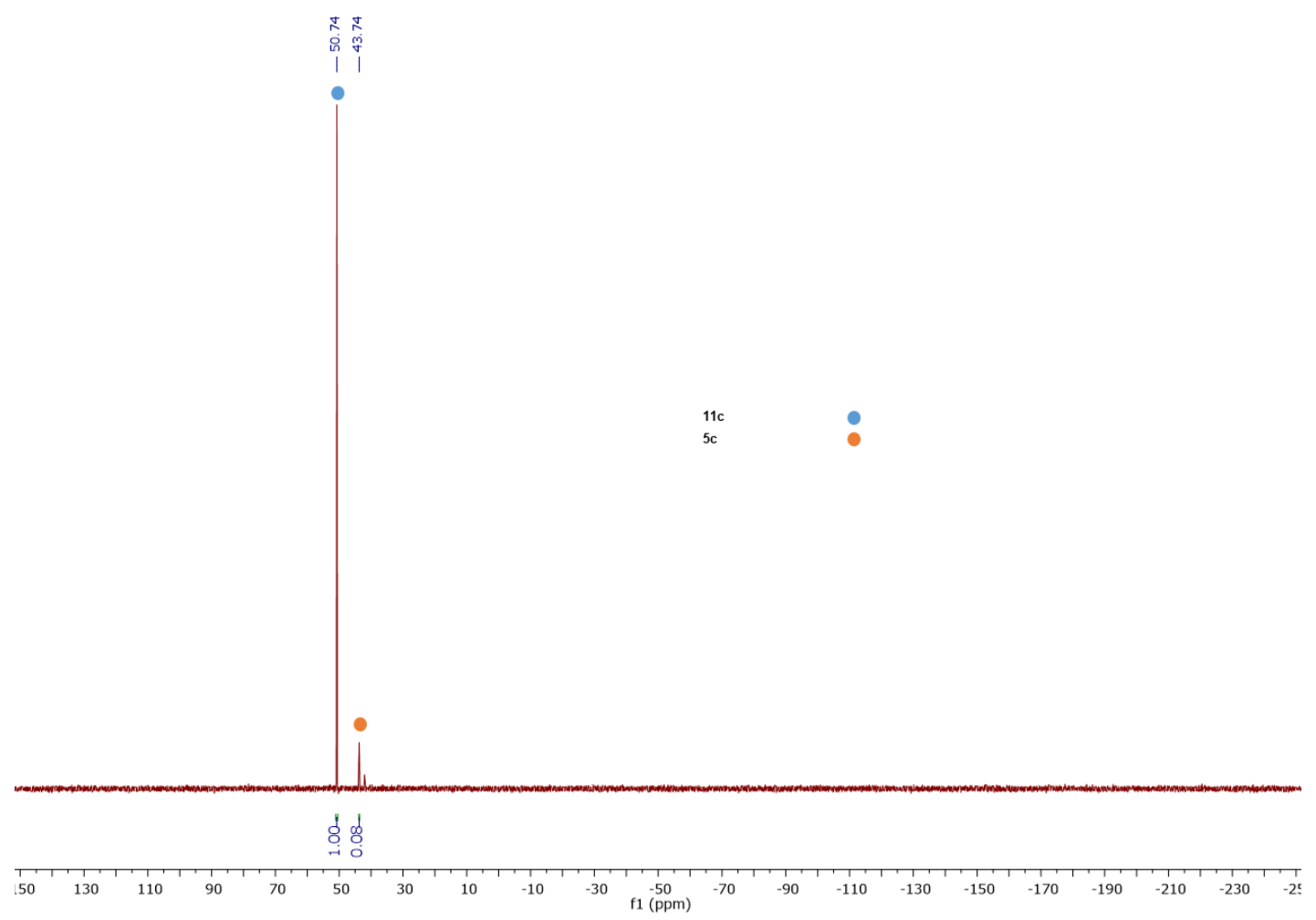

Figure S43. ${ }^{31} \mathrm{P}\left\{{ }^{1} \mathrm{H}\right\} \mathrm{NMR}\left(160 \mathrm{MHz}, \mathrm{THF}-\mathrm{d}_{8}, 298 \mathrm{~K}\right)$ spectrum of the transmetalation/reductive elimination on $\mathbf{9 c}$ after cyclooctadiene addition. 
Sample preparation for NMR characterization. In a $\mathrm{N}_{2}$-filled glovebox, [(dppe) $\left.\mathrm{NiBr}_{2}\right] \mathbf{4 c}$ ( $0.02 \mathrm{mmol}, 12.3 \mathrm{mg}, 1.0$ equiv) was charged in a $5 \mathrm{~mL}$ Schlenk, followed by THF $(0.5 \mathrm{~mL}$, $0.04 \mathrm{M})$. The Schlenk was sealed, taken out of the glovebox, cooled to $-40{ }^{\circ} \mathrm{C}$, and a $0.90 \mathrm{M}$ solution of vinyl magnesium bromide $2 \mathrm{a}$ in THF was added $(0.04 \mathrm{mmol}, 44 \mu \mathrm{L}, 2.0$ equiv). The reaction mixture was stirred at $-40{ }^{\circ} \mathrm{C}$ for 5 minutes, then a $0.40 \mathrm{M}$ stock solution of 1 -(buta1,3-dien-2-yl)-4-isobutylbenzene 3aa $(0.02 \mathrm{mmol}, 50 \mu \mathrm{L}, 1.0$ equiv) was added. The resulting dark red suspension was stirred at $-40{ }^{\circ} \mathrm{C}$ for 5 minutes and concentrated in vacuum at -40 ${ }^{\circ} \mathrm{C}$. The residue was dissolved in $0.5 \mathrm{~mL}$ of THF- $d_{8}$, the resulting solution was frozen in liquid nitrogen, the Schlenk was rapidly introduced in a $\mathrm{N}_{2}$-filled glovebox, and the solution was transferred in a J-Young tube which was immediately analyzed by NMR at $-30^{\circ} \mathrm{C}$.

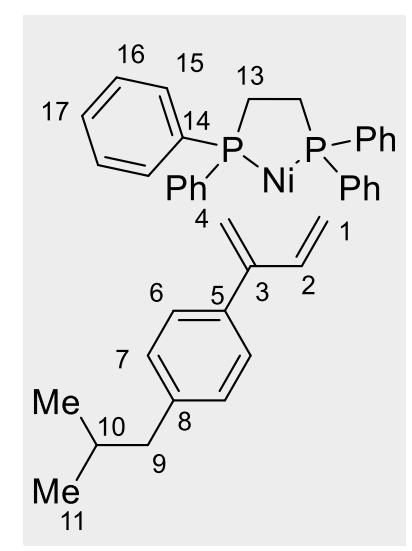

${ }^{1} \mathbf{H}$ NMR $\left(500 \mathrm{MHz}, \mathrm{THF}-d_{8}\right) \delta(\mathrm{ppm})=7.96-6.88(\mathrm{~m}, 22 \mathrm{H}, \mathrm{H}-6, \mathrm{H}-15$, $H-16, H-17), 6.68\left(\mathrm{~d},{ }^{3} J_{H H}=8.1 \mathrm{~Hz}, 1 \mathrm{H}, H-7\right), 5.27-5.14(\mathrm{~m}, 1 \mathrm{H}, H-$ 2), $3.42(\mathrm{~s}, 1 \mathrm{H}, H-4), 2.96(\mathrm{~d}, J=7.8 \mathrm{~Hz}, 1 \mathrm{H}, H-1), 2.27$ (d, ${ }^{3} J_{H H}=7.2$ $\mathrm{Hz}, 2 \mathrm{H}, \mathrm{H}-9), 2.26-1.96(\mathrm{~m}, 6 \mathrm{H}, \mathrm{H}-13, \mathrm{H}-1, \mathrm{H}-4), 0.81$ (d, ${ }^{3} \mathrm{~J}_{\mathrm{HH}}=6.5$ $\mathrm{Hz}, 6 \mathrm{H}, \mathrm{H}-11)$.

${ }^{13} \mathrm{C}\left\{{ }^{1} \mathrm{H}\right\}$ NMR $\left(130 \mathrm{MHz}, \mathrm{THF}-\mathrm{d}_{8}\right) \delta(\mathrm{ppm})=149.4(C-5), 140.2\left(\mathrm{dd}_{\mathrm{app}}\right.$, $\left.J_{P C}=26,5 \mathrm{~Hz}, C-14\right), 139.2(C-8), 133.8\left(\mathrm{~d}, J_{P C}=13 \mathrm{~Hz}, \mathrm{CH}-\mathrm{Ar}\right)$, $132.8\left(\mathrm{~d}, \mathrm{~J}_{\mathrm{PC}}=12 \mathrm{~Hz}, \mathrm{CH}-\mathrm{Ar}\right), 129.3(\mathrm{CH}-7), 129.0\left(\mathrm{~d}, \mathrm{~J}_{\mathrm{PC}}=9 \mathrm{~Hz}\right.$, $\mathrm{CH}-\mathrm{Ar}), 126.4(\mathrm{CH}-6), 105.2(\mathrm{C}-3), 89.9(\mathrm{CH}-2), 55.6\left(\mathrm{CH}_{2}-1\right), 51.9$ $\left(\mathrm{CH}_{2}-4\right), 45.9\left(\mathrm{CH}_{2}-9\right), 31.7-31.4\left(\mathrm{~m}, \mathrm{CH}_{2}-13, \mathrm{CH}-10\right), 23.0\left(\mathrm{CH}_{3}-11\right)$.

${ }^{31} \mathrm{P}\left\{{ }^{1} \mathrm{H}\right\}$ NMR $\left(160 \mathrm{MHz}, \mathrm{THF}-d_{8}, \mathrm{~T}=243 \mathrm{~K}\right) \delta(\mathrm{ppm})=69.8$ (s, broad), 30.2 (s, broad). 


\subsection{Transmetalation/Reductive elimination on $9 d$}

Transmetalation/Reductive elimination experiment. A similar procedure as the one followed for complex $\mathbf{4 c}$ led only to formation of diene $3 \mathbf{a a}$ with no possible quantification of the putative intermediate diene complex 11d. Hence a different experimental protocol was followed which only provides an estimate of the conversion into 11d.

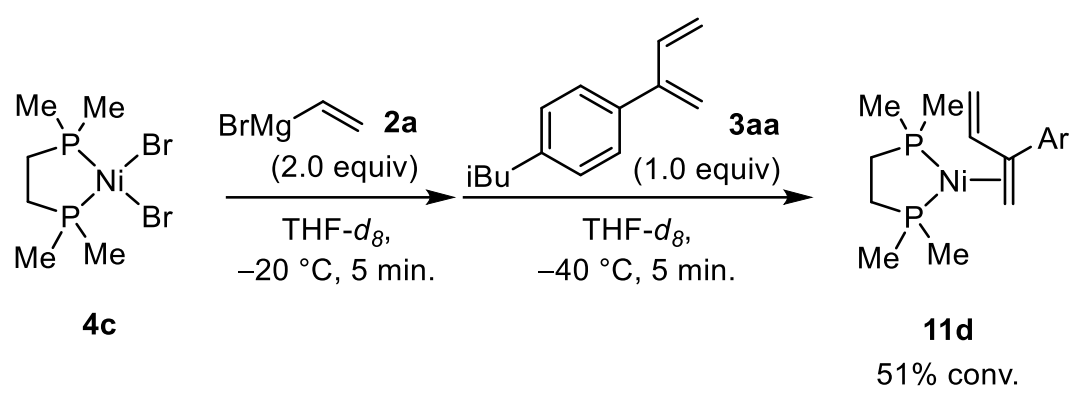

Figure S44.

Direct Butadiene displacement by 3aa experiment. In a $\mathrm{N}_{2}$-filled glovebox, [(dmpe) $\left.\mathrm{NiBr}_{2}\right]$ 4d $(0.03 \mathrm{mmol}, 11.06 \mathrm{mg}, 1.0$ equiv) was charged in a $5 \mathrm{~mL}$ Schlenk, followed by a $178 \mathrm{mM}$ stock solution of 1,3-di-tert-butyl-2-methoxy-5-methylbenzene in THF $(4.46 \mu \mathrm{mol}, 25 \mu \mathrm{L}, 0.15$ equiv) and THF (0.5 mL, $0.06 \mathrm{M})$. The Schlenk was sealed, taken out of the glovebox, cooled to $-20{ }^{\circ} \mathrm{C}$, and a $0.80 \mathrm{M}$ solution of vinyl magnesium bromide $\mathbf{2 a}$ in THF was added $(0.06$ mmol, $75 \mu \mathrm{L}, 2.0$ equiv). The reaction mixture was stirred at $-20^{\circ} \mathrm{C}$ for 5 minutes. The Schlenk was then cooled to $-40{ }^{\circ} \mathrm{C}$ and a $0.60 \mathrm{M}$ stock solution of 1-(buta-1,3-dien-2-yl)-4isobutylbenzene $3 \mathrm{aa}(0.03 \mathrm{mmol}, 50 \mu \mathrm{L}, 1.0$ equiv) was added. The mixture was stirred at $40{ }^{\circ} \mathrm{C}$ for $10 \mathrm{~min}$. The solvent was removed under vacuum for about 2 hours while keeping the Schlenk between -40 and $-20^{\circ} \mathrm{C}$. THF- $d_{8}$ was added to the Schlenk and the residue was dissolved again at $-40^{\circ} \mathrm{C}$. The Schlenk was cooled to $-78^{\circ} \mathrm{C}$ and cannulated into a J-Young NMR tube which was immediately analyzed at $-30^{\circ} \mathrm{C}$. From the analysis $51 \%$ conversion into diene complex $11 \mathrm{~d}$ could be estimated based on the aromatic protons at 7.08-7.06 ppm as well as full consumption of diene 3aa. 


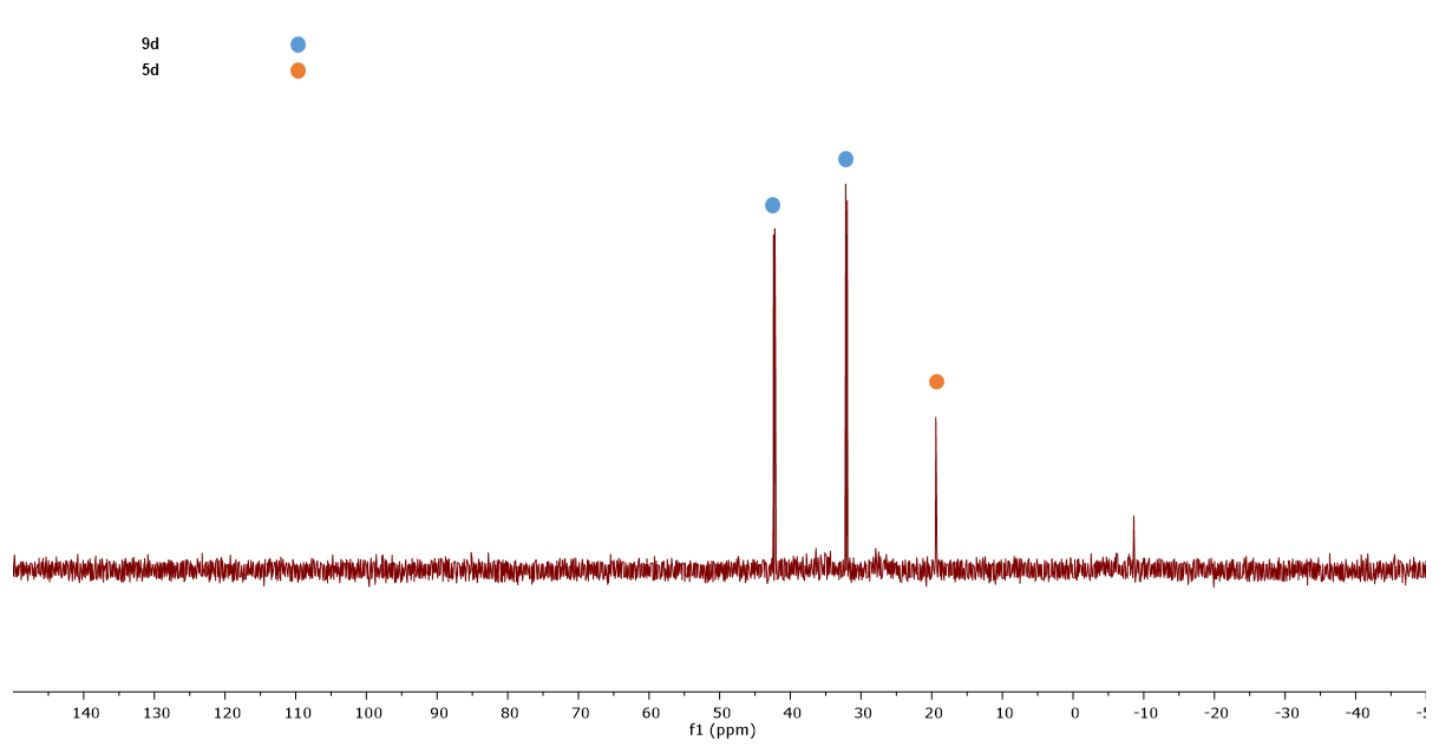

Figure S45. ${ }^{31} \mathrm{P}\left\{{ }^{1} \mathrm{H}\right\}$ NMR $\left(160 \mathrm{MHz}, \mathrm{THF}-\mathrm{d}_{8}, 243 \mathrm{~K}\right)$ spectrum of the transmetalation/reductive elimination experiment.

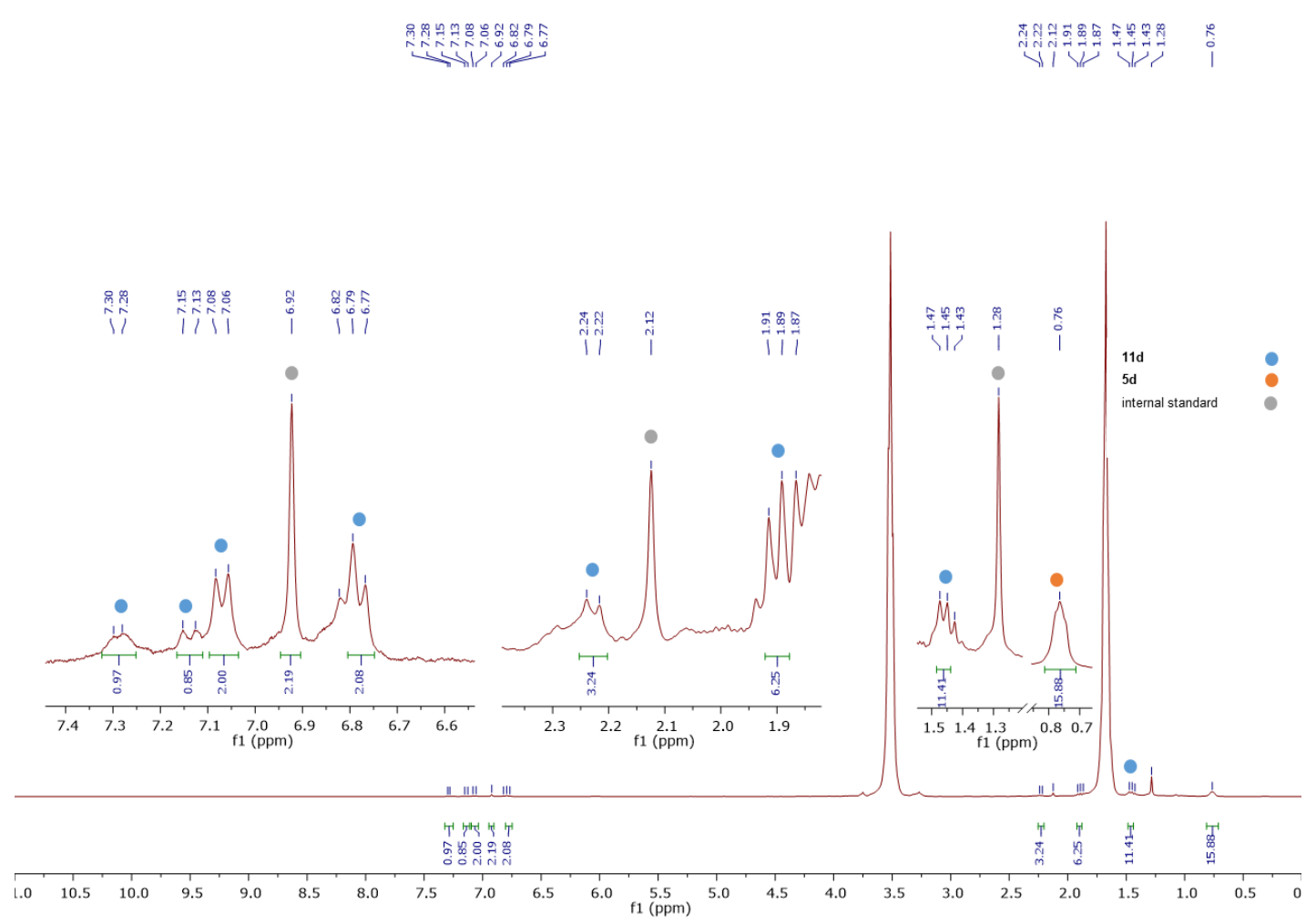

Figure S46. ${ }^{1} \mathrm{H}$ NMR $\left(300 \mathrm{MHz}, \mathrm{THF}-d_{8}, 243 \mathrm{~K}\right)$ spectrum of the direct butadiene displacement by $3 a$ a on $6 \mathrm{~d}$. 


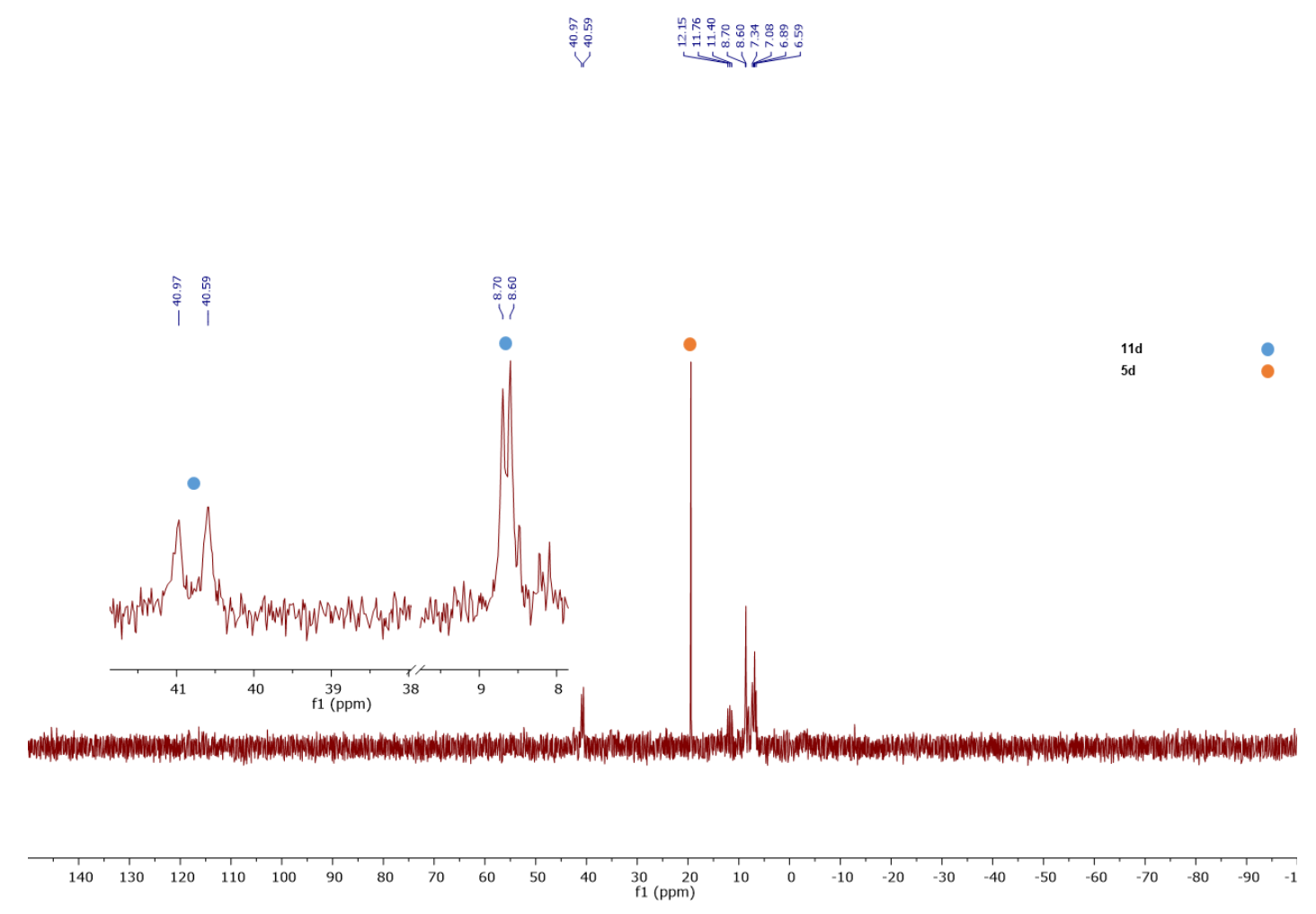

Figure S47. ${ }^{31} \mathrm{P}\left\{{ }^{1} \mathrm{H}\right\} \mathrm{NMR}\left(160 \mathrm{MHz}, \mathrm{THF}-\mathrm{d}_{8}, 243 \mathrm{~K}\right)$ spectrum of the direct butadiene displacement by $3 \mathbf{a a}$ on $\mathbf{6 d}$.

\section{NMR monitoring of the catalytic reaction}<smiles>C=C(O[P+](=O)OCC)c1ccc(CC(C)C)cc1</smiles>

1a

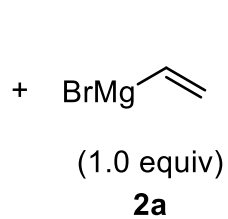

2a

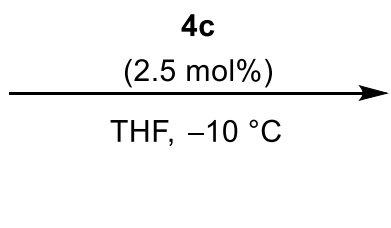

Figure S48.

In a $\mathrm{N}_{2}$-filled glovebox, [(dppe) $\left.\mathrm{NiBr}_{2}\right]$ 4c $(3.75 \mu \mathrm{mol}, 2.12 \mathrm{mg}, 2.5 \mathrm{~mol} \%)$, diethyl (1-(4isobutylphenyl)vinyl) phosphate 1a $(0.15 \mathrm{mmol}, 47.0 \mathrm{mg}, 1.0$ equiv) and 1,3-di-tert-butyl-2methoxy-5-methylbenzene (39 mmol, $9.0 \mathrm{mg}, 0.256$ equiv) were charged in a $5 \mathrm{~mL}$ Schlenk, followed by THF- $d_{8}(0.43 \mathrm{~mL})$. The Schlenk was sealed, taken out of the glovebox, cooled to $-10^{\circ} \mathrm{C}$, and a $0.90 \mathrm{M}$ solution of vinyl magnesium bromide $2 \mathrm{a}$ in THF was added $(0.15 \mathrm{mmol}$, $167 \mu \mathrm{L}, 1.0$ equiv). The reaction mixture was stirred at $-10^{\circ} \mathrm{C}$ for $60 \mathrm{sec}$, then quickly transferred by cannula in a J-Young NMR tube pre-cooled to $-78^{\circ} \mathrm{C}$. The reaction mixture was immediately analyzed by ${ }^{1} \mathrm{H}$ and ${ }^{31} \mathrm{P}$ NMR in a NMR pre-cooled at $-10^{\circ} \mathrm{C}$ (solution $\mathrm{J}$ ). At 
the time of recording ( $\mathrm{t}=\mathrm{ca} .10 \mathrm{~min}),{ }^{1} \mathrm{H}$ NMR indicated $69 \%$ consumption of enol phosphate 1a, $82 \%$ consumption of vinyl magnesium bromide $\mathbf{2 a}$ and $70 \%$ conversion into 1-(buta-1,3dien-2-yl)-4-isobutylbenzene 3aa. ${ }^{31} \mathrm{P}$ NMR suggested that the resting state of the catalytic system is the brominated oxidation complex $9 \mathrm{c}$. 


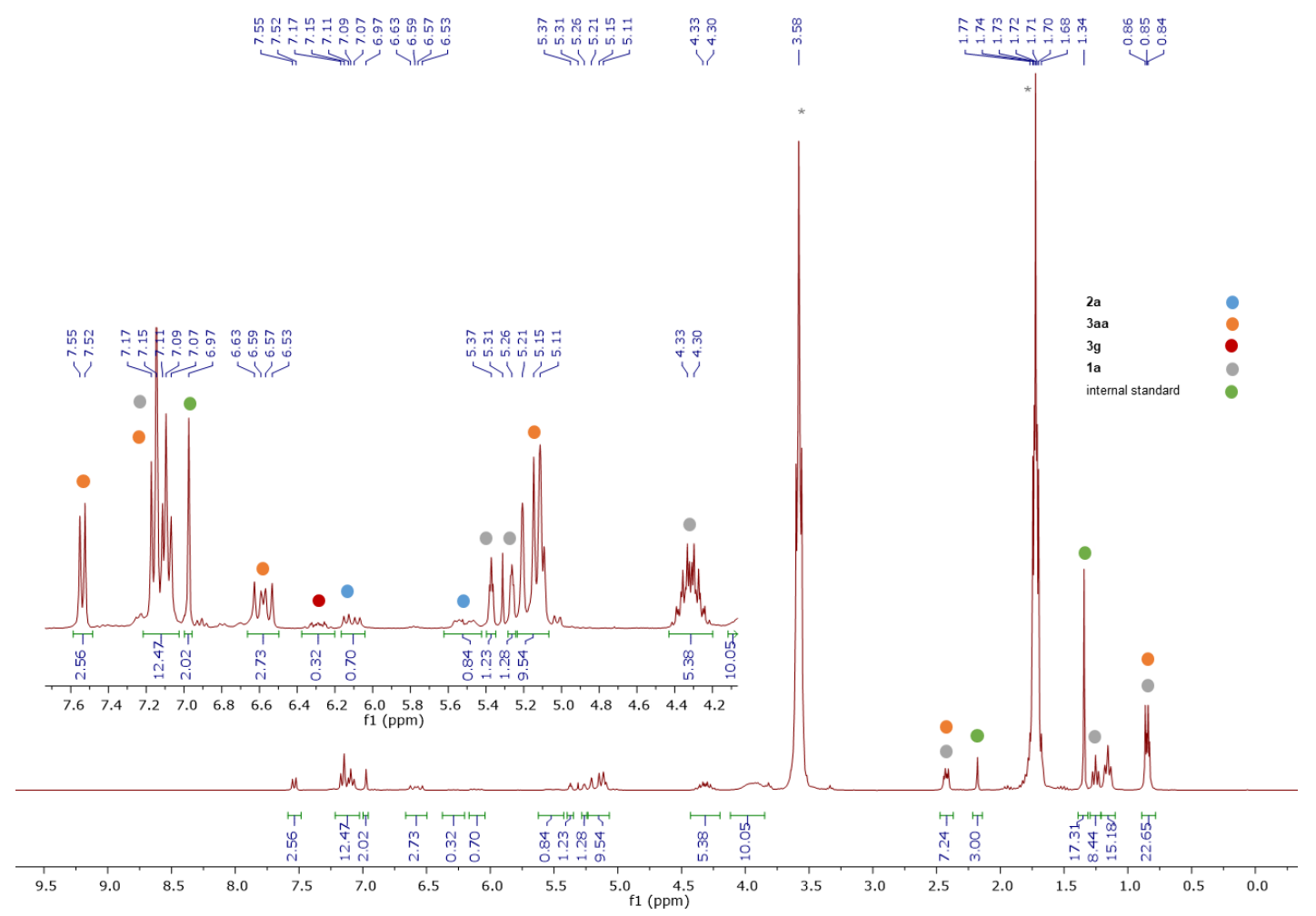

Figure S49. ${ }^{1} \mathrm{H}$ NMR $\left(300 \mathrm{MHz}, \mathrm{THF}-d_{8}, 263 \mathrm{~K}\right)$ spectrum of the catalytic reaction.

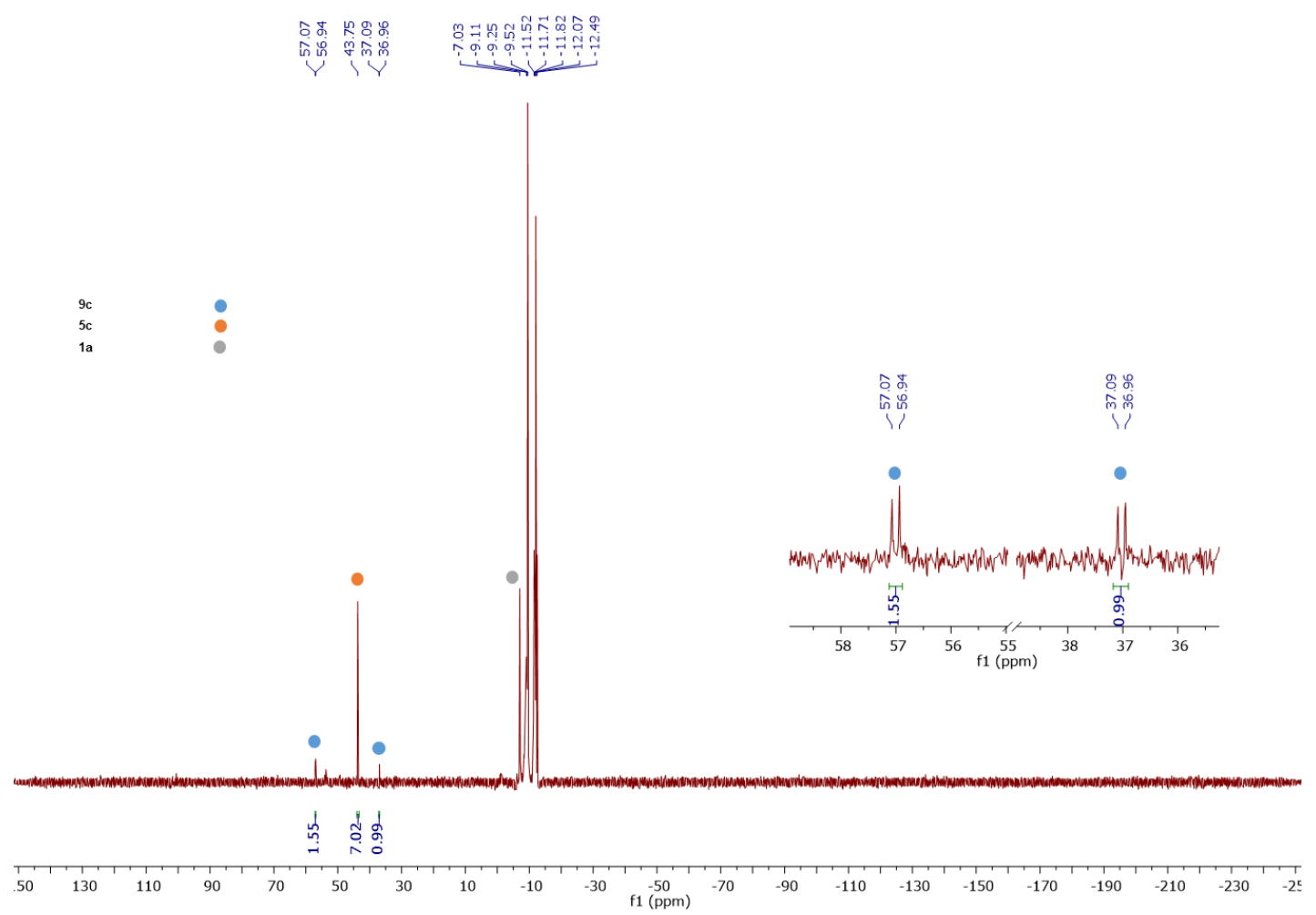

Figure S50. ${ }^{31} \mathrm{P}\left\{{ }^{1} \mathrm{H}\right\} \mathrm{NMR}\left(160 \mathrm{MHz}, \mathrm{THF}-d_{8}, 263 \mathrm{~K}\right)$ spectrum of the catalytic reaction. 


\section{Indirect evidence for the formation of vinyl nickel intermediates}
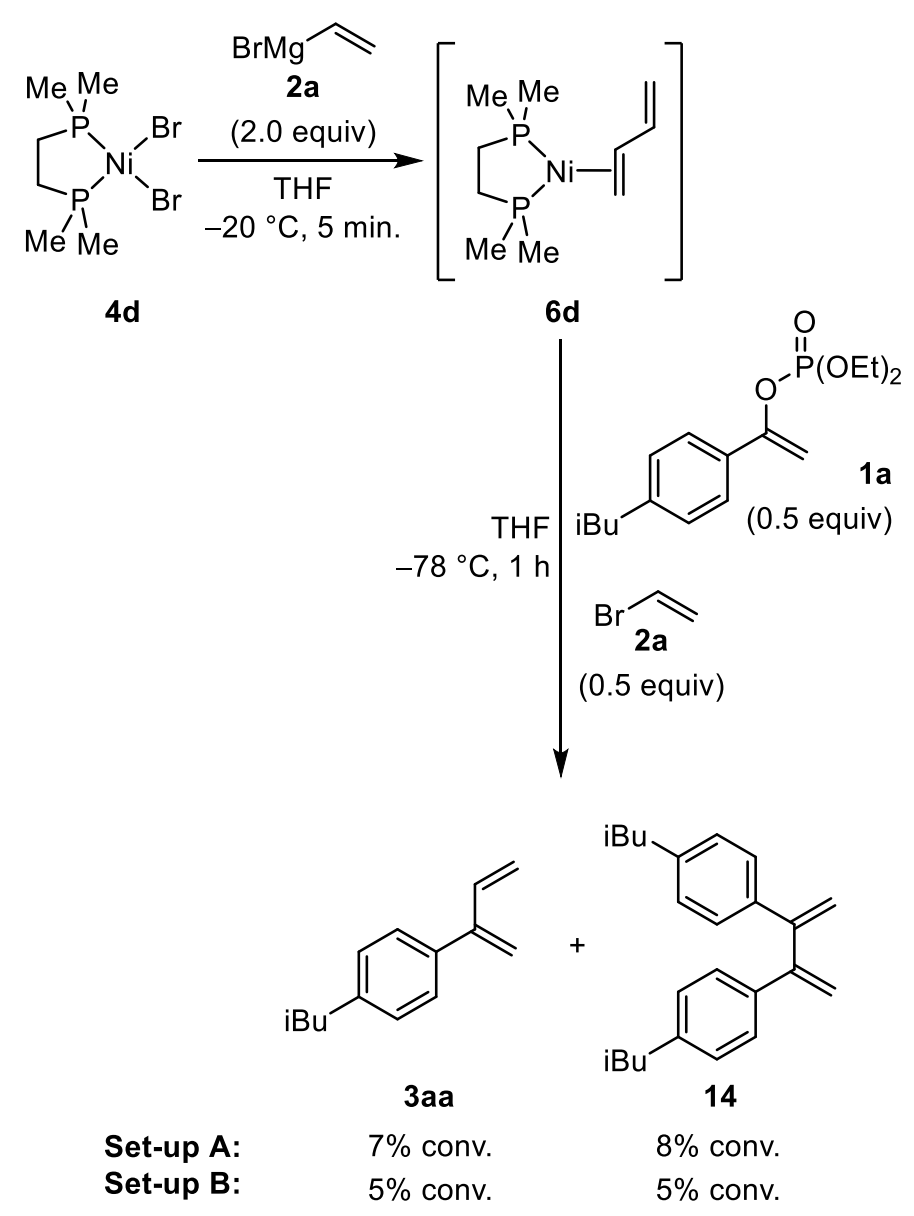

Figure S51.

Experiment using 1a. Set-up A. In a $\mathrm{N}_{2}$-filled glovebox, [(dmpe) $\left.\mathrm{NiBr}_{2}\right] 4 \mathbf{d}$ (110.6 mg, 0.3 mmol, 1 equiv) and THF (1.2 mL, $0.16 \mathrm{M}$ final concentration) were charged in a $10 \mathrm{~mL}$ Schlenk. The Schlenk was sealed, taken out of the glovebox, cooled to $-20^{\circ} \mathrm{C}$, and a $0.82 \mathrm{M}$ solution of vinyl magnesium bromide $2 \mathrm{a}$ in THF was added $(0.6 \mathrm{mmol}, 732 \mu \mathrm{L}, 2.0$ equiv). The orange suspension turned into a red solution while stirring for 5-10 minutes. The vessel was then frozen in a liquid nitrogen bath. To the frozen mixture were added a $1.5 \mathrm{M}$ diethyl (1-(4isobutylphenyl)vinyl) phosphate 1a stock solution in THF $(0.15 \mathrm{mmol}, 100 \mu \mathrm{L}, 0.5$ equiv) and a $1 \mathrm{M}$ vinyl bromide solution in THF $(0.15 \mathrm{mmol}, 150 \mu \mathrm{L}, 0.5$ equiv). The obtained mixture was put in a $-78^{\circ} \mathrm{C}$ bath to thaw and stir at that temperature. After 1 hour, ethyl acetate and pentane were added to the mixture, removed from the cold bath. Solvent addition led to precipitation of a brownish solid. The suspension was filtered through a silica pad. The obtained solution was dried over sodium sulfate, filtered and the solvent removed under vacuum affording the crude residue. An internal standard was added ( $p$-methylanisole), the conversion was determined by ${ }^{1} \mathrm{H}$ NMR of the crude reaction mixture: $7 \%$ conversion into free 
1-(buta-1,3-dien-2-yl)-4-isobutylbenzene 3aa and a 8\% conversion into 4,4'-(buta-1,3-diene2,3-diyl)bis(isobutylbenzene) 14.

Experiment using 1a. Set-up B. In a $\mathrm{N}_{2}$-filled glovebox, two separate $10 \mathrm{~mL}$ Schlenks $\mathbf{A}$ and B were both charged with [(dmpe) $\left.\mathrm{NiBr}_{2}\right]$ 4d $(110.6 \mathrm{mg}, 0.3 \mathrm{mmol}, 1$ equiv) and THF (1.2 mL, $0.16 \mathrm{M}$ final concentration). The Schlenks were sealed, taken out of the glovebox, cooled to $20{ }^{\circ} \mathrm{C}$, and a $0.82 \mathrm{M}$ solution of vinyl magnesium bromide $2 \mathrm{a}$ in THF was added $(0.6 \mathrm{mmol}$, $732 \mu \mathrm{L}, 2.0$ equiv). The orange suspension turned into a red solution while stirring for $5-10$ minutes. The Schlenks were then frozen in a nitrogen bath. To one of the frozen mixtures (Schlenk A) was added a 1.5 M diethyl (1-(4-isobutylphenyl)vinyl) phosphate 1a stock solution in THF (0.3 mmol, $100 \mu \mathrm{L}, 1.0$ equiv). To the other frozen mixture (Schlenk B) was added a 1 $\mathrm{M}$ vinyl bromide solution in THF $(0.3 \mathrm{mmol}, 300 \mu \mathrm{L}, 1.0$ equiv). Schlenk $\mathbf{A}$ was put back in a $78{ }^{\circ} \mathrm{C}$ bath and left to thaw while stirring at that temperature for 5 minutes. The content of Schlenk A was cannulated into frozen Schlenk B. The obtained mixture in Schlenk B was put in a $-78^{\circ} \mathrm{C}$ bath to thaw and stir at that temperature. After 1 hour, Schlenk B was removed from the cold bath. Ethyl acetate and pentane were added to the mixture. Solvent addition allowed the formation of precipitates. The suspension was filtered through a silica pad. The obtained solution was dried over sodium sulfate, filtered and the solvent removed under vacuum affording the crude residue. An internal standard was added ( $p$-methylanisole), the conversion was determined by ${ }^{1} \mathrm{H}$ NMR of the crude reaction mixture: $5 \%$ conversion into free 1-(buta-1,3-dien-2-yl)-4-isobutylbenzene 3aa and a 5\% conversion into 4,4'-(buta-1,3-diene2,3-diyl)bis(isobutylbenzene) 14. 


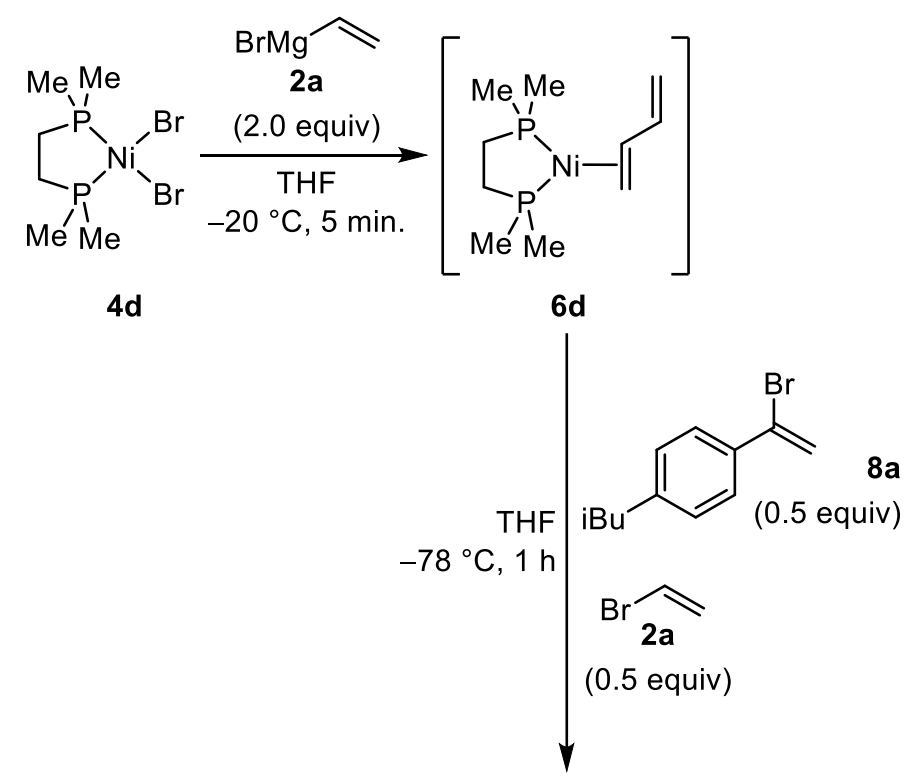

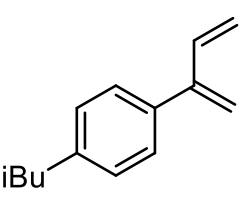

$3 a a$

Set-up A:

Set-up B:
$17 \%$ conv. $31 \%$ conv.<smiles>C=C(C(=C)c1ccc(CC(C)C)cc1)c1ccc(CC(C)C)cc1</smiles>

$8 \%$ conv. $9 \%$ conv.

Figure S52.

Experiment using 8a. Set-up A. In a $\mathrm{N}_{2}$-filled glovebox, [(dmpe) $\left.\mathrm{NiBr}_{2}\right] \mathbf{4 d}$ (110.6 mg, 0.3 mmol, 1 equiv) and THF (1.2 mL, $0.16 \mathrm{M}$ final concentration) were charged in a $10 \mathrm{~mL}$ Schlenk. The Schlenk was sealed, taken out of the glovebox, cooled to $-20^{\circ} \mathrm{C}$, and a $0.82 \mathrm{M}$ solution of vinyl magnesium bromide $2 \mathrm{a}$ in THF was added ( $0.6 \mathrm{mmol}, 732 \mu \mathrm{L}, 2.0$ equiv). The orange suspension turned into a red solution while stirring for 5-10 minutes. The Schlenk was frozen in a liquid nitrogen bath. To the frozen mixture were added a $1.5 \mathrm{M} \mathrm{1-(1-bromovinyl)-4-}$ isobutylbenzene $8 \mathrm{a}$ stock solution in THF $(0.15 \mathrm{mmol}, 100 \mu \mathrm{L}, 0.5$ equiv) and a $1 \mathrm{M}$ vinyl bromide solution in THF ( $0.15 \mathrm{mmol}, 150 \mu \mathrm{L}, 0.5$ equiv). The obtained mixture was put in a $78^{\circ} \mathrm{C}$ bath to thaw and stir at that temperature. After 1 hour, ethyl acetate and pentane were added to the mixtures, removed from the cold bath. Solvent addition allowed the formation of precipitates. The suspension was filtered through a silica pad. The obtained solution was dried over sodium sulfate, filtered and the solvent removed under vacuum affording the crude residue. An internal standard was added ( $p$-methylanisole), the conversion was determined by ${ }^{1} \mathrm{H}$ NMR of the crude reaction mixture: $17 \%$ conversion into free 1-(buta-1,3-dien-2-yl)-4isobutylbenzene 3aa and a $8 \%$ conversion into 4,4'-(buta-1,3-diene-2,3diyl)bis(isobutylbenzene) 14. 
Experiment using 8a. Set-up A. In a $\mathrm{N}_{2}$-filled glovebox, two separate $10 \mathrm{~mL}$ Schlenks $\mathbf{A}$ and B were both charged with $\left[(\mathrm{dmpe}) \mathrm{NiBr}_{2}\right]$ 4d $(110.6 \mathrm{mg}, 0.3 \mathrm{mmol}, 1$ equiv) and THF $(1.2 \mathrm{~mL}$, $0.16 \mathrm{M}$ final concentration). The Schlenks were sealed, taken out of the glovebox, cooled to $20{ }^{\circ} \mathrm{C}$, and a $0.82 \mathrm{M}$ solution of vinyl magnesium bromide $2 \mathrm{a}$ in THF was added $(0.6 \mathrm{mmol}$, $732 \mu \mathrm{L}, 2.0$ equiv). The orange suspension turned into a red solution while stirring for $5-10$ minutes. The Schlenks were then frozen in a nitrogen bath. To one of the frozen mixtures (Schlenk A) was added a 1.5 M M 1-(1-bromovinyl)-4-isobutylbenzene 8a stock solution in THF (0.3 mmol, $100 \mu \mathrm{L}, 1.0$ equiv). To the other frozen mixture (Schlenk B) was added a $1 \mathrm{M}$ vinyl bromide solution in THF ( $0.3 \mathrm{mmol}, 300 \mu \mathrm{L}, 1.0$ equiv). Schlenk $\mathbf{A}$ was put back in a -78 ${ }^{\circ} \mathrm{C}$ bath and left to thaw while stirring at that temperature for 5 minutes. The content of Schlenk A was cannulated into frozen Schlenk B. The obtained mixture in Schlenk B was put in a -78 ${ }^{\circ} \mathrm{C}$ bath to thaw and stir at that temperature. After 1 hour, Schlenk $\mathbf{B}$ was removed from the cold bath. Ethyl acetate and pentane were added to the mixture. Solvent addition allowed the formation of precipitates. The suspension was filtered through a silica pad. The obtained solution was dried over sodium sulfate, filtered and the solvent removed under vacuum affording the crude residue. An internal standard was added ( $p$-methylanisole), the conversion was determined by ${ }^{1} \mathrm{H}$ NMR of the crude reaction mixture: $31 \%$ conversion into free 1 -(buta1,3-dien-2-yl)-4-isobutylbenzene 3 aa and a 9\% conversion into 4,4'-(buta-1,3-diene-2,3diyl)bis(isobutylbenzene) 14.
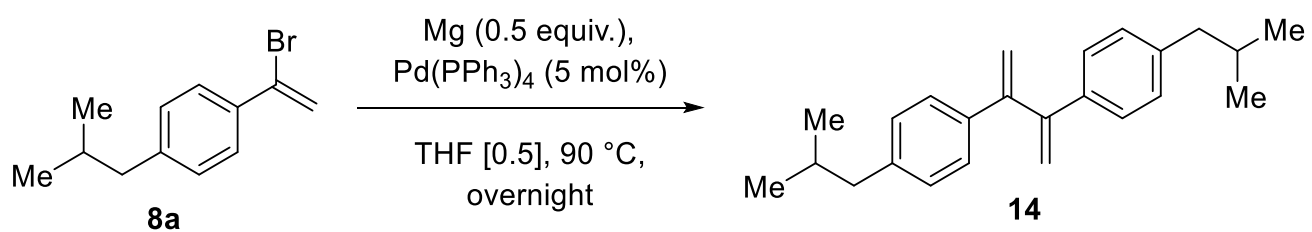

Figure S53.

Isolation and characterization of the homocoupling product (14). 4,4'-(buta-1,3-diene2,3-diyl)bis(isobutylbenzene) preparation was adapted from a literature procedure ${ }^{6}$. In a nitrogen filled glove box, a flame dried Schlenk containing magnesium $(2.1 \mathrm{mmol}, 51 \mathrm{mg}, 0.5$ equiv) was charged with $\mathrm{Pd}\left(\mathrm{PPh}_{3}\right)_{4}(0.21 \mathrm{mmol}, 243 \mathrm{mg}, 5 \mathrm{~mol} \%)$ and THF (8.4 mL, 0.5M). The Schlenk was taken out of the glove box and 1-(1-bromovinyl)-4-isobutylbenzene (4.2 mmol, $1 \mathrm{~g}, 1$ equiv) was added to the suspension. The mixture was heated overnight at $90^{\circ} \mathrm{C}$. The reaction was quenched with $\mathrm{NH}_{4} \mathrm{Cl}$. The aqueous phase was extracted with ethyl acetate. The organic phases were gathered, dried on $\mathrm{Na}_{2} \mathrm{SO}_{4}$ before removing the solvent under vacuum. A flash column chromatography with pentane afforded the desired product as a colorless oil: $553 \mathrm{mg}, 83 \%$ yield. 


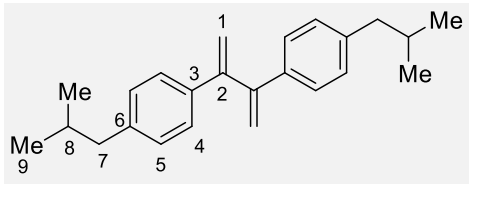

${ }^{1} \mathrm{H}$ NMR $\left(300 \mathrm{MHz}, \mathrm{CDCl}_{3}\right) \delta(\mathrm{ppm})=7.32\left(\mathrm{~d},{ }^{3} \mathrm{~J}_{\mathrm{HH}}=7.8 \mathrm{~Hz}, 4 \mathrm{H}\right.$, $H-4), 7.05\left(\mathrm{~d},{ }^{3} \mathrm{~J}_{\mathrm{HH}}=7.9 \mathrm{~Hz}, 4 \mathrm{H}, \mathrm{H}-5\right), 5.55(\mathrm{~s}, 2 \mathrm{H}, \mathrm{H}-1), 5.27$ (s, $2 \mathrm{H}, H-1), 2.44\left(\mathrm{~d},{ }^{3} \mathrm{~J}_{\mathrm{HH}}=7.2 \mathrm{~Hz}, 4 \mathrm{H}, \mathrm{H}-7\right), 1.84$ (hept, ${ }^{3} \mathrm{~J}_{\mathrm{HH}}=6.8$

$\mathrm{Hz}, 2 \mathrm{H}, H-8), 0.89\left(\mathrm{~d},{ }^{3} \mathrm{~J}_{\mathrm{HH}}=7.2 \mathrm{~Hz}, 12 \mathrm{H}, \mathrm{H}-9\right)$.

${ }^{13} \mathrm{C}\left\{{ }^{1} \mathrm{H}\right\}$ NMR $(75 \mathrm{MHz}, \mathrm{CDCl}) \delta(\mathrm{ppm})=149.9(C-2), 141.2(C-6), 137.7(C-3), 129.1(\mathrm{CH}-5)$, $127.3(\mathrm{CH}-4), 115.5\left(\mathrm{CH}_{2}-1\right), 45.3\left(\mathrm{CH}_{2}-7\right), 30.3(\mathrm{CH}-8), 22.5\left(\mathrm{CH}_{3}-9\right)$.

HRMS $\left(\mathrm{ESI}^{+}\right)$: calculated $[\mathrm{M}+\mathrm{H}]^{+}$for $\mathrm{C}_{24} \mathrm{H}_{30}: 319.2429$; found: 319.2421 .

IR (neat) $\vee\left(\mathrm{cm}^{-1}\right): 2954,2922,2868,1610,1510,1463,1384,1366,1229,1167,1120,1074$, $1019,898,848,803,740$.

\section{Radical clock and radical trapping experiments}

\subsection{Starting material synthesis}<smiles>CC(=O)c1ccccc1CC=C(C)C</smiles>

$15 \mathrm{~g}$

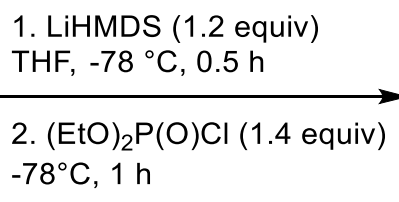

$-78^{\circ} \mathrm{C}, 1 \mathrm{~h}$<smiles>C=C(O[P+](=O)OCC)c1ccccc1CC=C(C)C</smiles>

$1 \mathrm{~g}$

Figure S54.

Under $\mathrm{N}_{2}$, a $1.0 \mathrm{M}$ solution of LiHMDS in THF (9.70 mmol, $9.70 \mathrm{~mL}, 1.2$ equiv) was added dropwise to a $-78^{\circ} \mathrm{C}$ solution of 1-(2-(3-methylbut-2-en-1-yl)phenyl)ethanone $15 \mathrm{~g}(8.07 \mathrm{mmol}$, $1.52 \mathrm{~g}, 1.0$ equiv) in THF (40 mL). The reaction mixture was stirred at $-78{ }^{\circ} \mathrm{C}$ for $1 \mathrm{~h}$, then allowed to warm to room temperature and stirred for 5 minutes. The reaction was then quenched by addition of a saturated solution of ammonium chloride at $0{ }^{\circ} \mathrm{C}$ and extracted three times with ethyl acetate. The organic layers were dried over sodium sulfate, filtered and the solvent removed under vacuum affording the crude residue. Purification by flash column chromatography over silica gel (40\% EtOAc/pentane) led to the desired product diethyl (1-(2(3-methylbut-2-en-1-yl)phenyl)vinyl) phosphate $1 \mathrm{~g}$ as a pale yellow oil $(2.53 \mathrm{~g}, 7.83 \mathrm{mmol}$, $97 \%$ yield). 


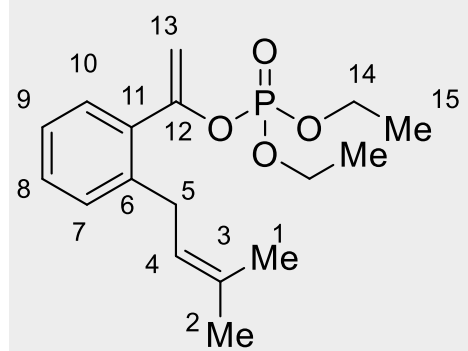

${ }^{1} \mathbf{H}$ NMR $\left(500 \mathrm{MHz}, \mathrm{CDCl}_{3}\right) \delta(\mathrm{ppm})=7.36\left(\mathrm{dd},{ }^{3} \mathrm{JHH}_{\mathrm{HH}}=7.6,{ }^{4} \mathrm{~J}_{\mathrm{HH}}\right.$ $=1.2 \mathrm{~Hz}, 1 \mathrm{H}, H-10), 7.29\left(\mathrm{td},{ }^{3} J_{\mathrm{HH}}=7.5 \mathrm{~Hz},{ }^{4} J_{\mathrm{HH}}=1.4 \mathrm{~Hz}, 1 \mathrm{H}\right.$, $H-8), 7.24-7.18(\mathrm{~m}, 1 \mathrm{H}, \mathrm{H}-7), 7.17\left(\mathrm{td},{ }^{3} \mathrm{~J}_{\mathrm{HH}}=7.5 \mathrm{~Hz},{ }^{4} \mathrm{~J}_{\mathrm{HH}}=1.4\right.$ $\mathrm{Hz}, 1 \mathrm{H}), 5.31\left(\mathrm{t}_{\mathrm{app}}, J=2.1 \mathrm{~Hz}, 1 \mathrm{H}, H-13\right), 5.28(\mathrm{~m}, H-4), 4.83$ (tapp, $J=2.1 \mathrm{~Hz}, 1 \mathrm{H}, H-13), 4.19-4.01(\mathrm{~m}, 4 \mathrm{H}, \mathrm{H}-14), 3.47$ (d, $\left.{ }^{3} J_{\mathrm{HH}}=7.2 \mathrm{~Hz}, 2 \mathrm{H}, \mathrm{H}-5\right), 1.75-1.72(\mathrm{~m}, 3 \mathrm{H}, \mathrm{H}-1$ or $\mathrm{H}-2), 1.70$ (s, $3 \mathrm{H}, \mathrm{H}-1$ or $H-2), 1.28\left(\mathrm{td},{ }^{3} \mathrm{~J}_{\mathrm{HH}}=7.1,{ }^{4} J_{\mathrm{PH}}=1.1 \mathrm{~Hz}, 6 \mathrm{H}, \mathrm{H}-15\right)$.

${ }^{13} \mathrm{C}\left\{{ }^{1} \mathrm{H}\right\}$ NMR $\left(130 \mathrm{MHz}, \mathrm{CDCl}_{3}\right) \delta(\mathrm{ppm})=153.3\left(\mathrm{~d},{ }^{2} \mathrm{JPC}_{\mathrm{PC}}=8 \mathrm{~Hz}, \mathrm{C}-12\right), 140.3(C-11), 135.2$ $\left(\mathrm{d},{ }^{4} \mathrm{JPC}_{\mathrm{PC}}=6 \mathrm{~Hz}, \mathrm{C}-6\right), 132.8(\mathrm{C}-3), 129.7(\mathrm{CH}-10), 129.31(\mathrm{CH}-7$ or $\mathrm{CH}-8), 129.30(\mathrm{CH}-7$ or $\mathrm{CH}-8), 125.8(\mathrm{CH}-9), 123.1(\mathrm{CH}-4), 102.0\left(\mathrm{~d},{ }^{3} \mathrm{JPC}_{\mathrm{PC}}=4 \mathrm{~Hz}, \mathrm{CH}_{2}-13\right), 64.4\left(\mathrm{~d},{ }^{2} \mathrm{JPC}_{\mathrm{PC}}=6 \mathrm{~Hz}, \mathrm{CH}_{2^{-}}\right.$ 14), $31.9\left(\mathrm{CH}_{2}-5\right), 25.9\left(\mathrm{CH}_{3}-1\right.$ or $\left.\mathrm{CH}_{3}-2\right), 18.0\left(\mathrm{CH}_{3}-1\right.$ or $\left.\mathrm{CH}_{3}-2\right), 16.2\left(\mathrm{~d},{ }^{3} \mathrm{JPC}_{\mathrm{PC}}=7 \mathrm{~Hz}, \mathrm{CH}_{3}-\right.$ 15).

${ }^{31} \mathrm{P}\left\{{ }^{1} \mathrm{H}\right\} \mathbf{N M R}\left(160 \mathrm{MHz}, \mathrm{CDCl}_{3}\right) \delta(\mathrm{ppm})=-6.81(\mathrm{~s})$.

HRMS $\left(\mathrm{ESI}^{+}\right)$: calculated $[\mathrm{M}+\mathrm{Na}]^{+}$for $\mathrm{C}_{17} \mathrm{H}_{25} \mathrm{O}_{4} \mathrm{PN}_{\mathrm{a}}^{+}$: 347.1383 ; found: 347.1393 .

IR (neat) $\vee\left(\mathrm{cm}^{-1}\right):$ 2982, 2914, 1647, 1483, 1446, 1373, 1272, 1165, 1099, 1025, 989, 836, $802,769,751$.

\subsection{Cross-coupling experiments}<smiles>C=C(O[P+](=O)OCC)c1ccccc1CC=C(C)C</smiles>

$1 \mathrm{~g}$

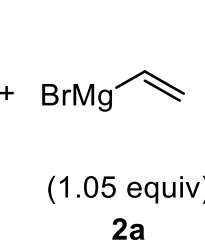

$2 \mathbf{a}$

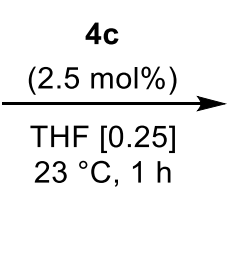

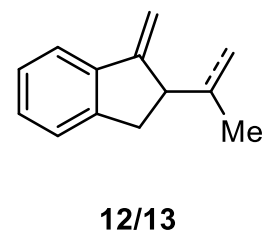

not observed

Figure S55.

Cross-coupling experiments using 4c. In a $\mathrm{N}_{2}$-filled glovebox, the precatalyst [(dppe) $\mathrm{NiBr}_{2}$ ] 4c (0.025 mmol, $15.4 \mathrm{mg}, 2.5 \mathrm{~mol} \%)$ and diethyl (1-(2-(3-methylbut-2-en-1-yl)phenyl)vinyl) phosphate $1 \mathrm{~g}$ (1.0 mmol, $324 \mathrm{mg}, 1.0$ equiv) were charged in a $10 \mathrm{~mL}$ Schlenk and dissolved in THF (2.7 mL, final concentration: $0.25 \mathrm{M})$. The Schlenk was sealed, taken out of the glovebox, cooled to $0^{\circ} \mathrm{C}$, and a $0.83 \mathrm{M}$ solution of vinyl magnesium bromide $2 \mathrm{a}$ in THF was added dropwise ( $1.05 \mathrm{mmol}, 1.3 \mathrm{~mL}, 1.05$ equiv). The reaction mixture was stirred at room temperature for $1 \mathrm{~h}$. The reaction was then quenched by addition of a saturated solution of ammonium chloride and extracted three times with ethyl acetate. The organic layers were dried over sodium sulfate, filtered and the solvent removed under vacuum affording the crude residue. An internal standard was added ( $p$-methylanisole), the conversion was determined 
by ${ }^{1} \mathrm{H}$ NMR of the crude reaction mixture ( $81 \%$ conversion). No traces of the cyclized product could be detected. Purification by flash column chromatography over silica gel (100\% pentane) led to the desired product 1-(buta-1,3-dien-2-yl)-2-(3-methylbut-2-en-1-yl)benzene 3ag as a clear colorless oil $(0.80 \mathrm{mmol}, 158 \mathrm{mg}, 80 \%$ yield).

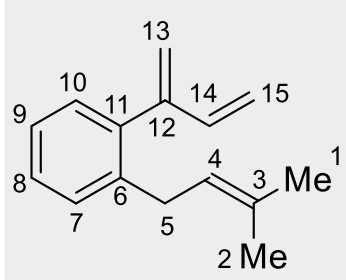

${ }^{1} \mathbf{H}$ NMR $\left(500 \mathrm{MHz}, \mathrm{CDCl}_{3}\right) \delta(\mathrm{ppm})=7.30-7.19(\mathrm{~m}, 2 \mathrm{H}, \mathrm{H}-9, \mathrm{H}-10)$, $7.18\left(\mathrm{td},{ }^{3} J_{\mathrm{HH}}=7.2 \mathrm{~Hz},{ }^{4} \mathrm{~J}_{\mathrm{HH}}=1.7 \mathrm{~Hz}, 1 \mathrm{H}, \mathrm{H}-8\right), 7.10-7.02(\mathrm{~m}, 1 \mathrm{H}, \mathrm{H}$ 7), $6.64\left(\mathrm{dd},{ }^{3} \mathrm{~J}_{\mathrm{HH}}=17.3,10.4 \mathrm{~Hz}, 1 \mathrm{H}, H-14\right), 5.44-5.36(\mathrm{~m}, 1 \mathrm{H}, \mathrm{H}-13)$, $5.26-5.20(\mathrm{~m}, 1 \mathrm{H}, H-4), 5.13\left(\mathrm{~d},{ }^{3} \mathrm{~J}_{\mathrm{HH}}=10.3 \mathrm{~Hz}, 1 \mathrm{H}, H-15\right), 5.08(\mathrm{~s}, 1 \mathrm{H}$, $H-13$ ), 4.77-4.68 (m, 1H, H-15), 3.24 (dapp, $J=7.2 \mathrm{~Hz}, 2 \mathrm{H}, H-5), 1.71$ (s, 3H, $H-1$ or $H-2), 1.66$ (s, 3H, $H-1$ or $H-2$ ).

${ }^{13} \mathrm{C}\left\{{ }^{1} \mathrm{H}\right\}$ NMR $\left(130 \mathrm{MHz}, \mathrm{CDCl}_{3}\right) \delta(\mathrm{ppm})=148.4(\mathrm{C}-12), 139.9(\mathrm{C}-6), 139.3(\mathrm{CH}-14), 139.0$ (C-11), $132.1(\mathrm{C}-3), 129.8(\mathrm{CH}-7), 128.8(\mathrm{CH}-9), 127.5(\mathrm{CH}-10), 125.6(\mathrm{CH}-8), 123.8(\mathrm{CH}-4)$, $118.6(\mathrm{CH}-13), 117.2(\mathrm{CH}-15), 31.7\left(\mathrm{CH}_{2}-5\right), 25.9\left(\mathrm{CH}_{3}-1\right.$ or $\left.\mathrm{CH}_{3}-2\right), 18.0\left(\mathrm{CH}_{3}-1\right.$ or $\left.\mathrm{CH}_{3}-2\right)$.

GCMS $\left(\mathrm{El}^{+}\right)$: calculated $[\mathrm{M}]^{+}$for $\mathrm{C}_{15} \mathrm{H}_{18}: 198.14$; found: 198.10 .

IR (neat) $\vee\left(\mathrm{cm}^{-1}\right):$ 2970, 2916, 1737, 1589, 1486, 1446, 1378, 1314, 1103, 1036, 988, 900, $854,765,746$.<smiles>C=C(OC(=O)c1ccccc1CC=C(C)C)O[P+](=O)OCC</smiles>

19

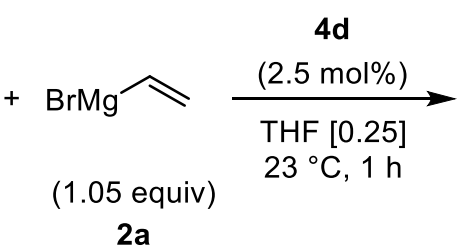

$2 a$

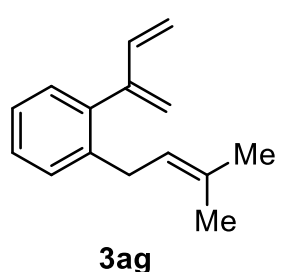

$70 \%$ conv.

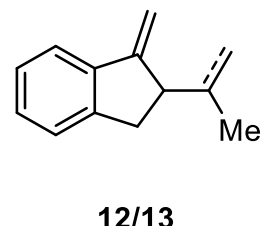

not observed

Figure S56.

Cross-coupling experiment using 4d. In a $\mathrm{N}_{2}$-filled glovebox, the precatalyst [(dmpe) $\left.\mathrm{NiBr}_{2}\right]$ 4d (0.025 mmol, $9.2 \mathrm{mg}, 2.5 \mathrm{~mol} \%)$ and diethyl (1-(2-(3-methylbut-2-en-1-yl)phenyl)vinyl) phosphate $1 \mathrm{~g}$ (1.0 mmol, $324 \mathrm{mg}, 1.0$ equiv) were charged in a $10 \mathrm{~mL}$ Schlenk and dissolved in THF (2.7 mL, final concentration: $0.25 \mathrm{M})$. The Schlenk was sealed, taken out of the glovebox, cooled to $0^{\circ} \mathrm{C}$, and a $0.83 \mathrm{M}$ solution of vinyl magnesium bromide in THF was added dropwise (1.05 mmol, $1.3 \mathrm{~mL}, 1.05$ equiv). The reaction mixture was stirred at room temperature for $1 \mathrm{~h}$. The reaction was then quenched by addition of a saturated solution of ammonium chloride and extracted three times with ethyl acetate. The organic layers were dried over sodium sulfate, filtered and the solvent removed under vacuum affording the crude residue. An internal standard was added ( $p$-methylanisole), the conversion was determined 
by ${ }^{1} \mathrm{H}$ NMR of the crude reaction mixture (70\% conversion). No traces of the cyclized product could be detected by both ${ }^{1} \mathrm{H}$ NMR and GC-MS.

\subsection{TEMPO-trapping experiments}<smiles>C=C(O[P+](=O)OCC)c1ccccc1CC=C(C)C</smiles>

$1 \mathrm{~g}$<smiles>C=CC(=O)OCC(=O)O</smiles>

2a

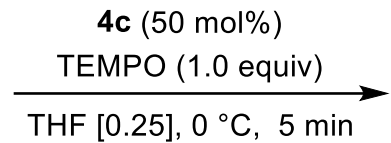

THF [0.25], $0{ }^{\circ} \mathrm{C}, 5 \mathrm{~min}$

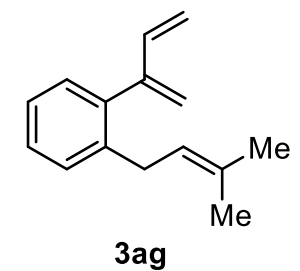

4c: $79 \%$ conv.

Figure S57.

TEMPO-trapping experiment using 4c. In a $\mathrm{N}_{2}$-filled glovebox, the precatalyst [(dppe) $\mathrm{NiBr}_{2}$ ] 4c (0.155 mmol, $95.1 \mathrm{mg}, 50 \mathrm{~mol} \%)$, TEMPO (0.31 mmol, $48 \mathrm{mg}, 1.0$ equiv) and diethyl (1-(2(3-methylbut-2-en-1-yl)phenyl)vinyl) phosphate $1 \mathrm{~g}(0.31 \mathrm{mmol}, 100 \mathrm{mg}, 1.0$ equiv) were charged in a $5 \mathrm{~mL}$ Schlenk and dissolved in THF $(0.5 \mathrm{~mL}$, final concentration: $0.25 \mathrm{M})$. The Schlenk was sealed, taken out of the glovebox, cooled to $0^{\circ} \mathrm{C}$, and a $0.83 \mathrm{M}$ solution of vinyl magnesium bromide $2 \mathbf{a}$ in THF was added dropwise $(2.0 \mathrm{mmol}, 0.74 \mathrm{~mL}, 2.0$ equiv). The reaction mixture was stirred at $0^{\circ} \mathrm{C}$ for 5 minutes. The reaction was then quenched by addition of a saturated solution of ammonium chloride and extracted three times with ethyl acetate. The organic layers were dried over sodium sulfate, filtered and the solvent removed under vacuum affording the crude residue. An internal standard was added ( $p$-methylanisole), the conversion was determined by ${ }^{1} \mathrm{H}$ NMR of the crude reaction mixture (79\% conversion). No traces of any TEMPO adduct could be detected by NMR, GC/MS or LC/MS.<smiles>C=C(O[P+](=O)OCC)c1ccccc1CC=C(C)C</smiles>

$1 \mathrm{~g}$

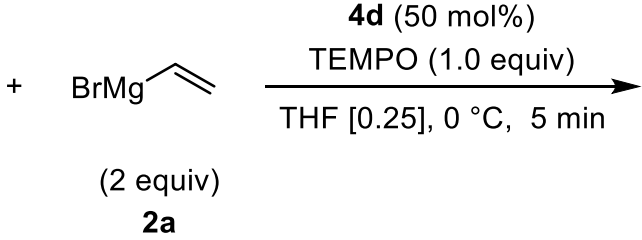

2a

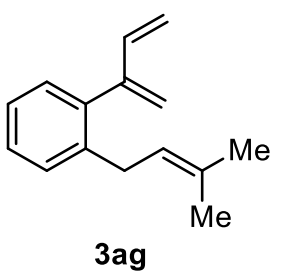

4d: $57 \%$ conv.

Figure S58.

TEMPO-trapping experiment using 4d. In a $\mathrm{N}_{2}$-filled glovebox, the precatalyst [(dmpe) $\mathrm{NiBr}_{2}$ ] 4d (0.155 mmol, $57.1 \mathrm{mg}, 50 \mathrm{~mol} \%)$, TEMPO (0.31 mmol, $48 \mathrm{mg}, 1.0$ equiv) and diethyl (1(2-(3-methylbut-2-en-1-yl)phenyl)vinyl) phosphate $\mathbf{1 g}(0.31 \mathrm{mmol}, 100 \mathrm{mg}, 1.0$ equiv) were 
charged in a $5 \mathrm{~mL}$ Schlenk and dissolved in THF (0.5 mL, final concentration: $0.25 \mathrm{M})$. The Schlenk was sealed, taken out of the glovebox, cooled to $0^{\circ} \mathrm{C}$, and a $0.83 \mathrm{M}$ solution of vinyl magnesium bromide 2a in THF was added dropwise $(2.0 \mathrm{mmol}, 0.74 \mathrm{~mL}, 2.0$ equiv). The reaction mixture was stirred at $0^{\circ} \mathrm{C}$ for 5 minutes. The reaction was then quenched by addition of a saturated solution of ammonium chloride and extracted three times with ethyl acetate. The organic layers were dried over sodium sulfate, filtered and the solvent removed under vacuum affording the crude residue. An internal standard was added ( $p$-methylanisole), the conversion was determined by ${ }^{1} \mathrm{H}$ NMR of the crude reaction mixture (57\% conversion). No traces of any TEMPO adduct could be detected by NMR, GC/MS or LC/MS.

\section{Kinetic study}

In-situ FT-IR monitoring was carried out in $10 \mathrm{~mL}$ 2-necked jacketed glass reactors fitted with a ReactIR $45 \mathrm{~m}$ probe. Enol phosphate 1a consumption was monitored using its absorption peak at $1640 \mathrm{~cm}^{-1}$ (1613 $\mathrm{cm}^{-1}$ when 1-(1-bromovinyl)-4-isobutylbenzene 8a was used as substrate and $1649 \mathrm{~cm}^{-1}$ when 1-((3r,5r,7r)-adamantan-1-yl)vinyl diethyl phosphate 1d). The raw absorption data was converted into concentration data assuming that the Beer-Lamber law applied in the used range of concentration. These profiles were then analyzed using the principles of VTNA. ${ }^{7}$ Only one set of experiment is shown for clarity purposes, although each experiment was performed two to three times to ensure reproducibility.

\subsection{Standard reaction procedure}

[(dppe) $\mathrm{NiBr}_{2}$ ] system. Under $\mathrm{N}_{2}$, a dry 2-necked jacketed glass reactor was fitted with the IR probe, THF was added $(2.61 \mathrm{~mL})$ and the system was cooled to $-10{ }^{\circ} \mathrm{C}$. After temperature equilibrium was reached (ca. $5 \mathrm{~min}$ ), an infrared background was acquired. A $0.90 \mathrm{M}$ solution of vinyl magnesium bromide $2 \mathrm{a}$ was added $(1.0 \mathrm{mmol}, 1.11 \mathrm{~mL})$, followed by diethyl (1-(4isobutylphenyl)vinyl) phosphate $\mathbf{1 a}(1.0 \mathrm{mmol}, 312.0 \mathrm{mg})$. The temperature was equilibrated and absorption data was collected for 5 minutes. In parallel, under $\mathrm{N}_{2}$, a $2 \mathrm{~mL}$ Schlenk was charged with [(dppe) $\mathrm{NiBr}_{2}$ ] $4 \mathrm{c}(0.05 \mathrm{mmol}, 30.9 \mathrm{mg})$ and THF $(0.39 \mathrm{~mL})$. The resulting suspension was cooled to $-40{ }^{\circ} \mathrm{C}$, a $0.90 \mathrm{M}$ solution of vinyl magnesium bromide 1a was added $(0.1 \mathrm{mmol}, 111 \mu \mathrm{L})$ and the reaction mixture was stirred at $-40{ }^{\circ} \mathrm{C}$ for 5 minutes, then at room temperature until homogeneous ( $<1 \mathrm{~min}$ ). Catalysis was initiated by immediately injecting $250 \mu \mathrm{L}$ of the resulting solution in the glass reactor containing the other reagents, thus resulting in the following initial concentrations: $[4 \mathrm{c}]_{i}=6.25 \mathrm{mM},[1 \mathrm{a}]_{i}=0.25 \mathrm{M},[2 \mathrm{a}]_{i}=0.25$ $M$. The reaction was monitored for $1 \mathrm{~h}$, with 1 point $/ 5 \mathrm{sec}$ for the first 2 minutes, then 1 point $/ 10$ 
sec for the following 2 minutes, then 1 point/30 sec for the following 10 minutes, then 1 point/60 $\mathrm{sec}$ for the remainder of the reaction. The reaction was then quenched by addition of a saturated solution of ammonium chloride at $-10^{\circ} \mathrm{C}$ and extracted three times with ethyl acetate. The organic layers were dried over sodium sulfate, filtered and the solvent removed under vacuum affording the crude residue. Enol phosphate 1a consumption and diene 3aa conversion were determined by ${ }^{1} \mathrm{H}$ NMR using $p$-methylanisole as an internal standard.

[(dmpe) $\mathrm{NiBr}_{2}$ ] system. Under $\mathrm{N}_{2}$, a dry 2-necked jacketed glass reactor was fitted with the IR probe, THF was added $(2.53 \mathrm{~mL})$ and the system was cooled to $-40^{\circ} \mathrm{C}$. After temperature equilibrium was reached (ca. $15 \mathrm{~min}$ ), an infrared background was acquired. A 0.82 M solution of vinyl magnesium bromide $2 \mathrm{a}$ was added $(1.0 \mathrm{mmol}, 1.22 \mathrm{~mL})$, followed by diethyl (1-(4isobutylphenyl)vinyl) phosphate $\mathbf{1 a}(1.0 \mathrm{mmol}, 312.0 \mathrm{mg})$. The temperature was equilibrated and absorption data was collected for 5 minutes. In parallel, under $\mathrm{N}_{2}$, a $2 \mathrm{~mL}$ Schlenk was charged with [(dmpe) $\left.\mathrm{NiBr}_{2}\right] \mathbf{4 d}(0.03 \mathrm{mmol}, 11.06 \mathrm{mg})$ and THF $(0.430 \mathrm{~mL})$. The resulting suspension was cooled to $-20^{\circ} \mathrm{C}$, a $0.82 \mathrm{M}$ solution of vinyl magnesium bromide $2 \mathrm{a}$ was added $(0.06 \mathrm{mmol}, 75 \mu \mathrm{L})$ and the reaction mixture was stirred at $-20{ }^{\circ} \mathrm{C}$ for 5 minutes. Catalysis was initiated by immediately injecting $250 \mu \mathrm{L}$ of the resulting solution in the glass reactor containing the other reagents, thus resulting in the following initial concentrations: $[\mathbf{4 d}]_{i}$ $=3.75 \mathrm{mM},[\mathbf{1} \mathrm{a}]_{i}=0.25 \mathrm{M},[2 \mathrm{a}]_{i}=0.25 \mathrm{M}$. The reaction was monitored for $1 \mathrm{~h}$, with $1 \mathrm{point} / 5$ sec for the first 2 minutes, then 1 point/10 sec for the following 2 minutes, then 1 point/30 sec for the following 10 minutes, then 1 point/ $60 \mathrm{sec}$ for the remainder of the reaction. The reaction was then quenched by addition of a saturated solution of ammonium chloride at $-40{ }^{\circ} \mathrm{C}$ and extracted three times with ethyl acetate. The organic layers were dried over sodium sulfate, filtered and the solvent removed under vacuum affording the crude residue. Enol phosphate 1a consumption and diene 3aa conversion were determined by ${ }^{1} \mathrm{H}$ NMR using $p$-methylanisole as an internal standard.

Similar procedures were used to perform kinetic studies using substrates $\mathbf{8 a}$ and $\mathbf{1 d}$. 


\subsection{Kinetic study with $4 c$ as precatalyst}

All the following reaction were performed according to the corresponding standard reaction procedures using the concentrations in reagents and catalyst mentioned in the plots.

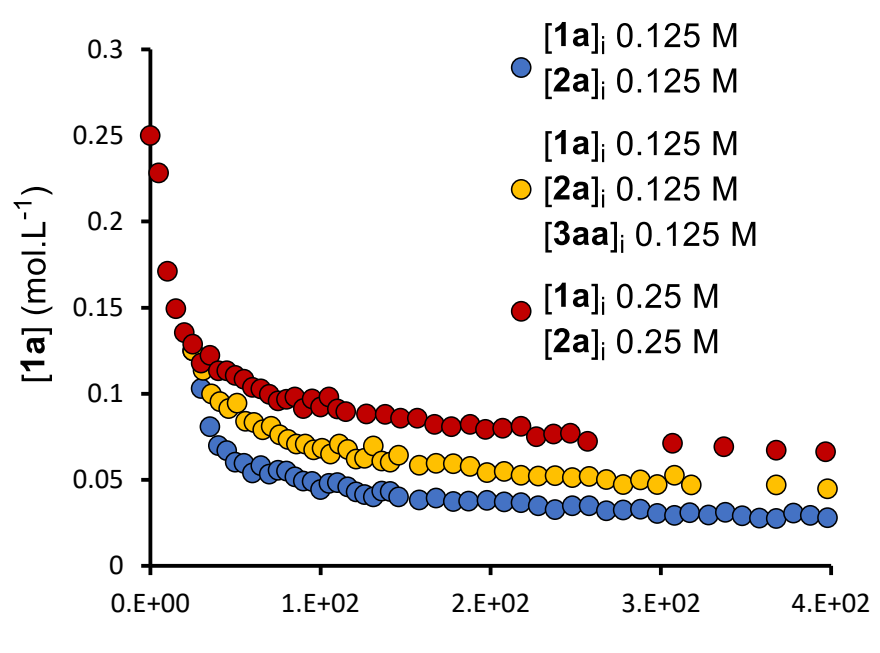

$t(\mathrm{~s})$

Figure S59. Same excess experiments

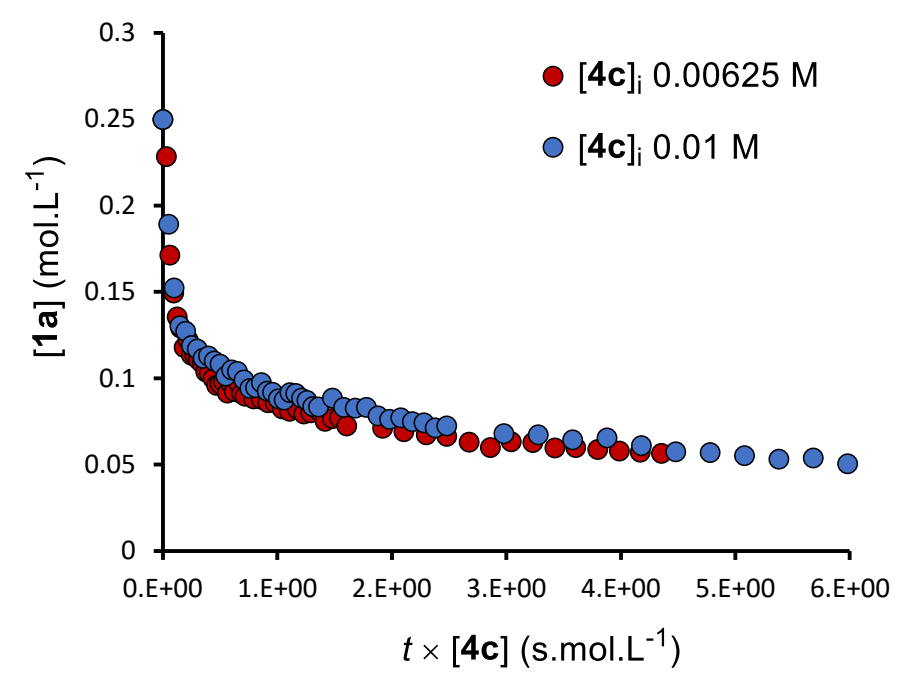

Figure S60. Order in 4c - Different excess experiment 


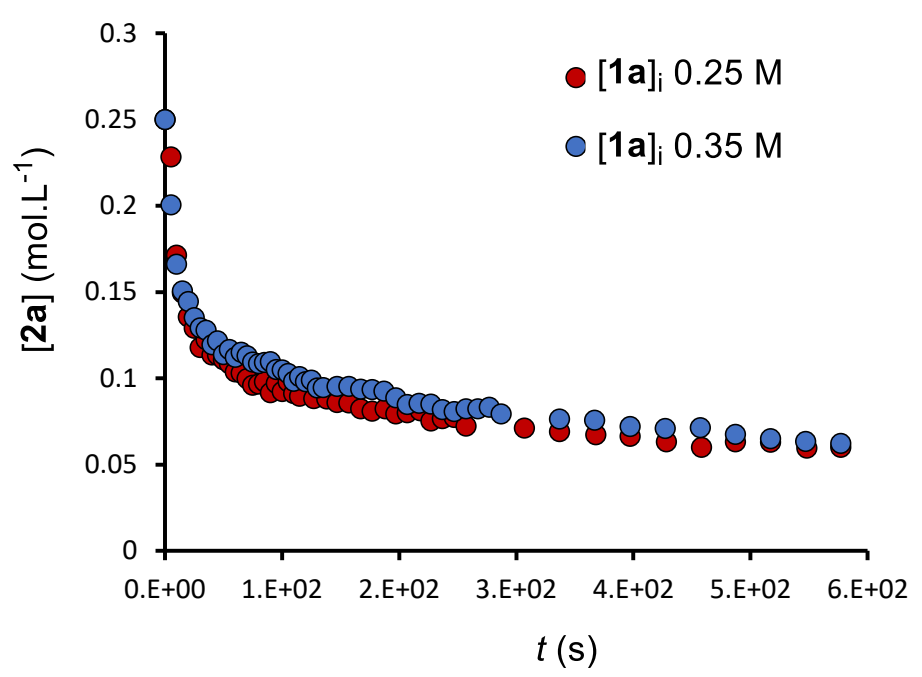

Figure S61. Order in 1a - Different excess experiment

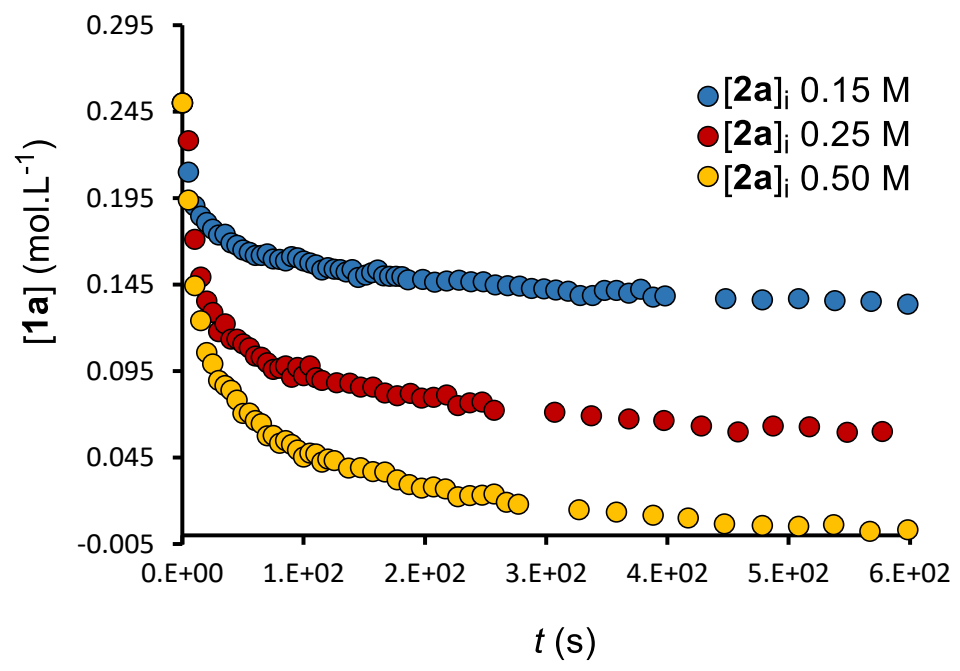

Figure S62. Order in $\mathbf{2 a}$ - Different excess experiment 


\subsection{Kinetic study with $4 d$ as precatalyst}

All the following reaction were performed according to the corresponding standard reaction procedures using the concentrations in reagents and catalyst mentioned in the plots.

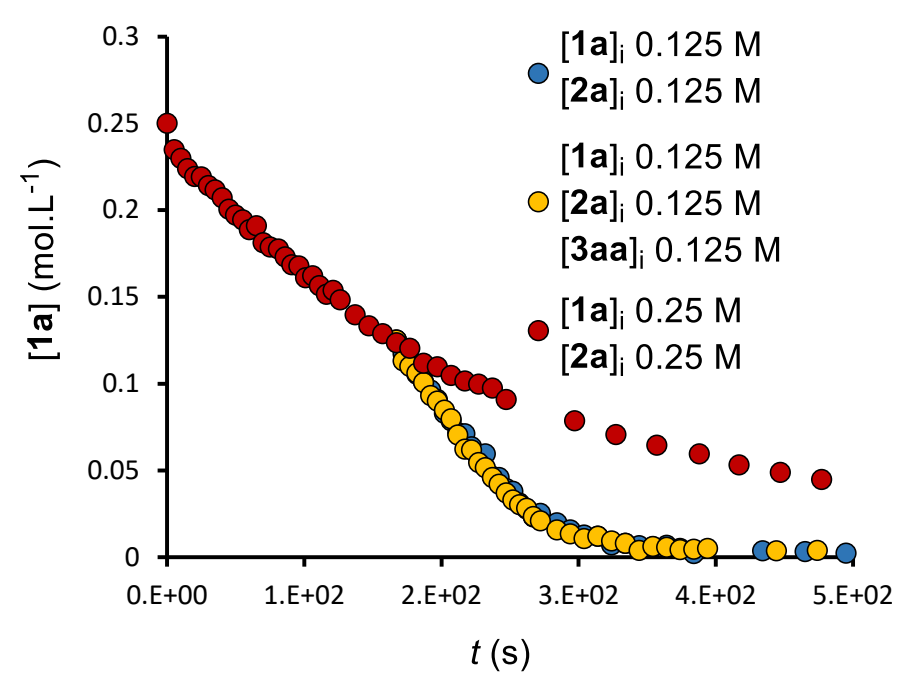

Figure S63. Same excess experiment

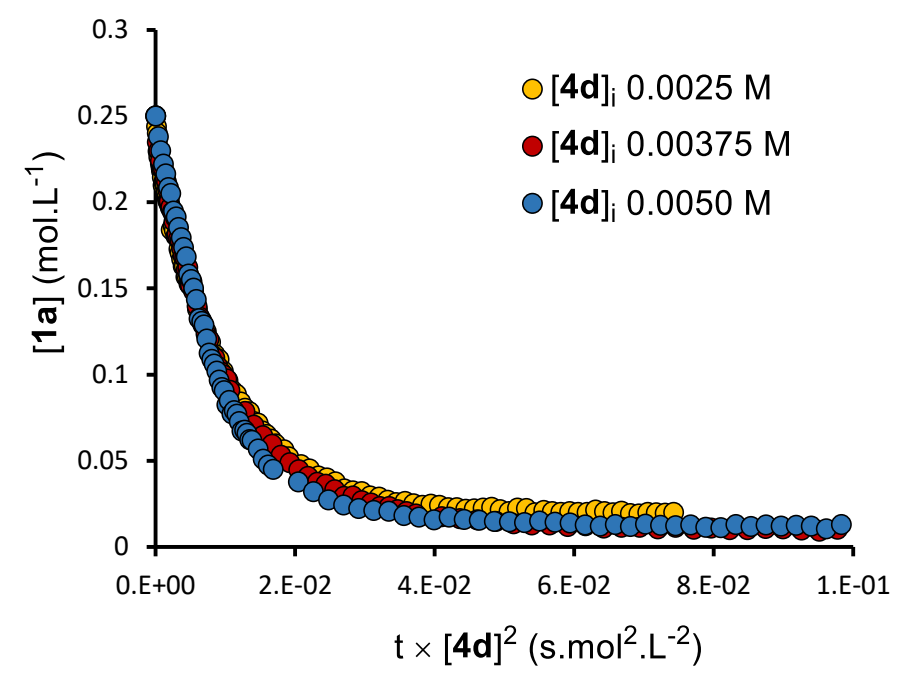

Figure S64. Order in 4d - Different excess experiment with 1a 


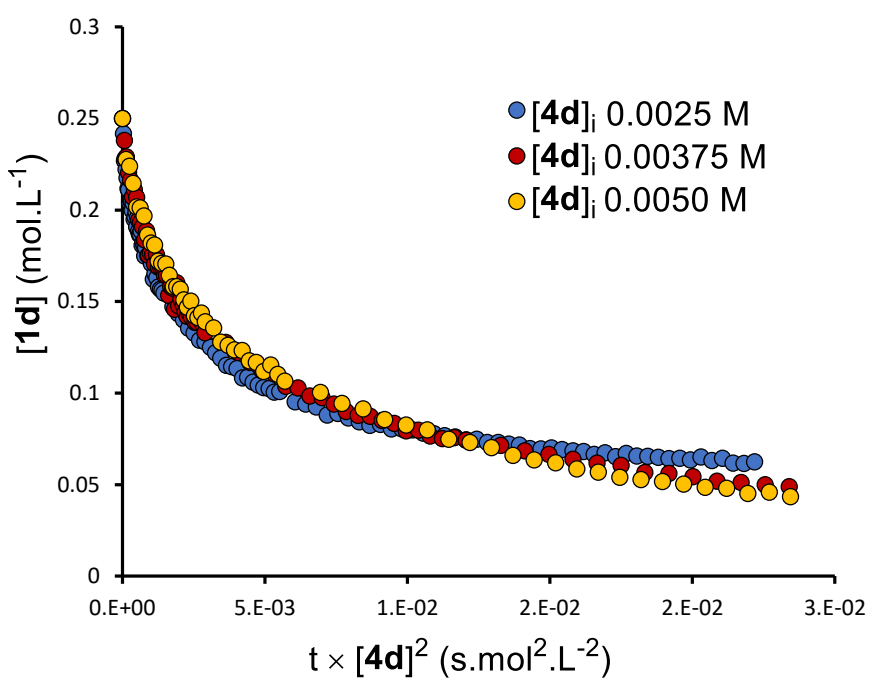

Figure S65. Order in 4d - Different excess experiment with 1d

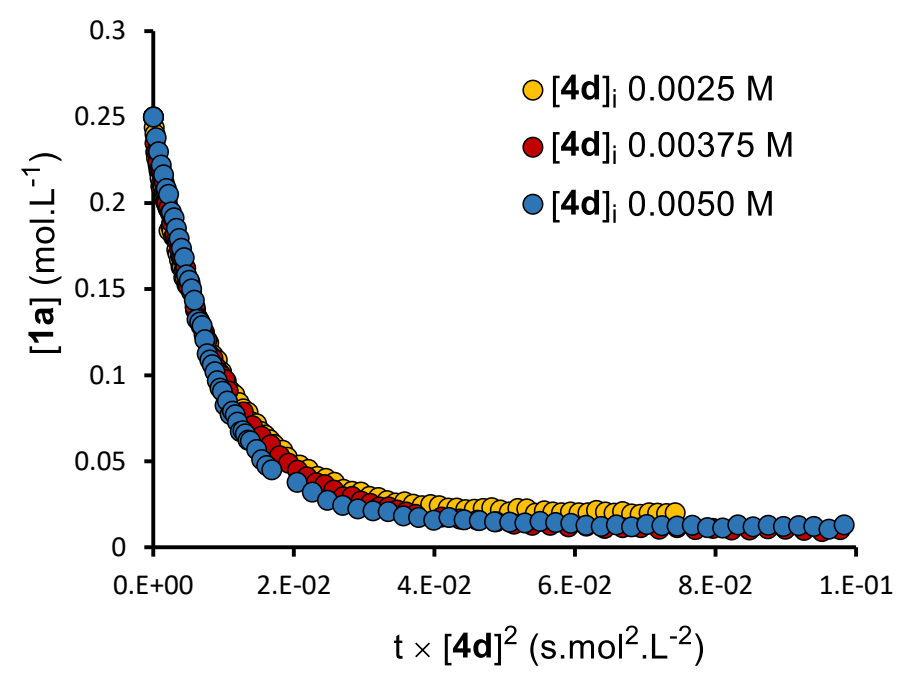

Figure S66. Order in 1a - Different excess experiment 


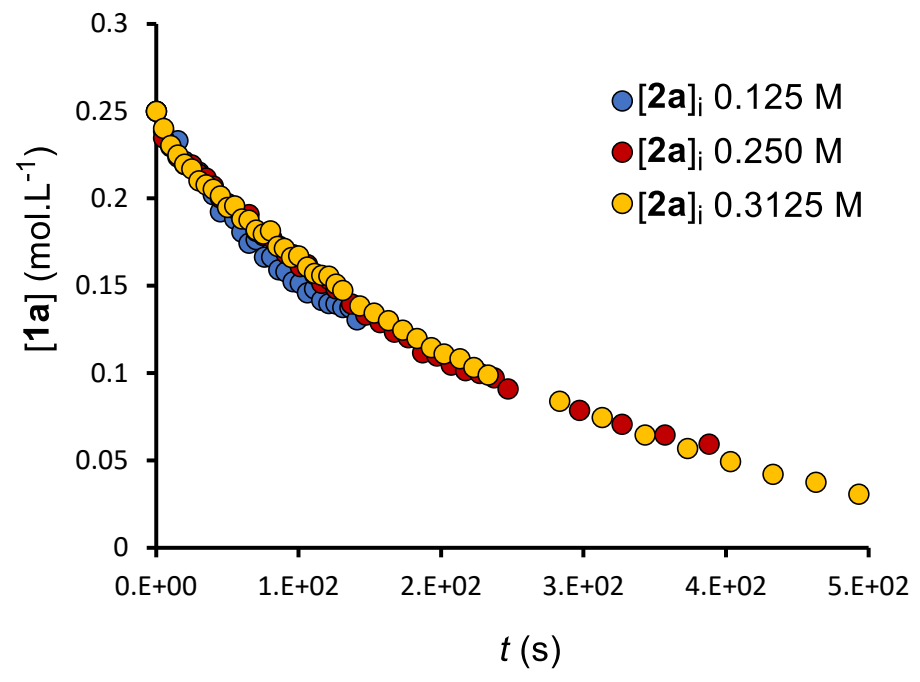

Figure S67. Order in 2a - Different excess experiment

\section{X-Ray analyses}

All data were collected on an Agilent Supernova diffractometer equipped with an ATLAS CCD detector using $\mathrm{Cu}$ radiation. The crystal was kept at 180.01(10) K during data collection. Using Olex2, the structure was solved with the ShelXT structure solution program using Intrinsic Phasing and refined with the ShelXL refinement package using Least Squares minimization. Crystallographic data are found in Table S1-3 
Table S1. Crystal structure and data refinement for 7c (CCDC 2116219)

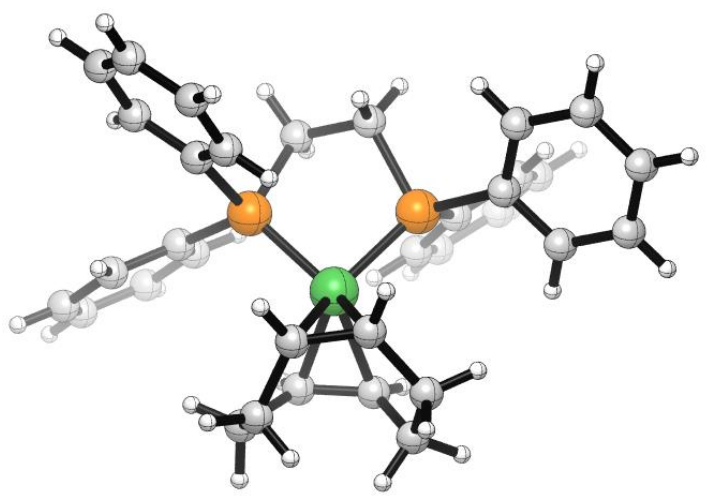

Identification code

CCDC

Empirical formula

Formula weight

Temperature/K

Crystal system

Space group

$\mathrm{a} / \AA$

$\mathrm{b} / \AA$

$\mathrm{c} / \AA ̊ \AA$

$\alpha /{ }^{\circ}$

$\beta /{ }^{\circ}$

$\mathrm{Y} /{ }^{\circ}$

Volume $/ \AA^{3}$

Z

$\rho_{\text {calc }} \mathrm{g} / \mathrm{cm}^{3}$

7c

2116219

$\mathrm{C}_{34} \mathrm{H}_{36} \mathrm{NiP}_{2}$

565.28

180.01(10)

monoclinic

$\mathrm{P} 2{ }_{1} / \mathrm{n}$

11.46823(15)

17.03648(19)

$15.04101(17)$

90

108.6432(13)

90

$2784.49(6)$

4

1.348

2.241

$\mu / \mathrm{mm}^{-1}$

1192.0

$F(000)$

Crystal size $/ \mathrm{mm}^{3}$

$0.289 \times 0.248 \times 0.081$

Radiation

$2 \Theta$ range for data collection/ ${ }^{\circ}$

CuKa $(\lambda=1.54184)$

Index ranges

Reflections collected

8.088 to 141.928

$-13 \leq h \leq 13,-20 \leq k \leq 20,-16 \leq \mathrm{I} \leq 18$

19605

Independent reflections

Data/restraints/parameters

Goodness-of-fit on $\mathrm{F}^{2}$

$5244\left[R_{\text {int }}=0.0348, R_{\text {sigma }}=0.0282\right]$

$5244 / 0 / 334$

1.044

Final $R$ indexes $[I>=2 \sigma(I)]$

Final $R$ indexes [all data]

$\mathrm{R}_{1}=0.0302, \mathrm{wR}_{2}=0.0748$

$\mathrm{R}_{1}=0.0389, \mathrm{wR}_{2}=0.0801$

Largest diff. peak/hole / e $\AA^{-3}$

$0.27 /-0.24$ 
Table S2. Crystal structure and data refinement for 7d (CCDC 2116218)

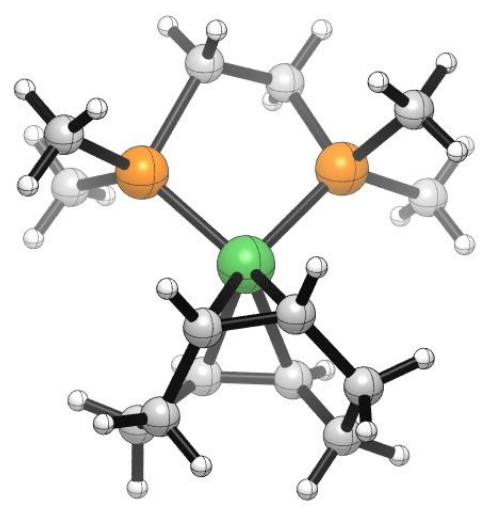

Identification code

CCDC

Empirical formula

Formula weight

Temperature/K

Crystal system

Space group

$\mathrm{a} / \AA$

$\mathrm{b} / \AA ̊ \AA$

$\mathrm{c} / \AA ̊ \AA$

$\alpha /{ }^{\circ}$

$\beta /{ }^{\circ}$

$\mathrm{Y} /{ }^{\circ}$

Volume/ $/ \AA^{3}$

Z

$\rho_{\text {calc }} \mathrm{g} / \mathrm{cm}^{3}$

$\mu / \mathrm{mm}^{-1}$

$F(000)$

Crystal size $/ \mathrm{mm}^{3}$

Radiation

$2 \Theta$ range for data collection $/^{\circ}$

Index ranges

Reflections collected

Independent reflections

Data/restraints/parameters

Goodness-of-fit on $\mathrm{F}^{2}$

Final $R$ indexes [l>=2 $\sigma(I)]$

Final $R$ indexes [all data]

Largest diff. peak/hole / e $\AA^{-3}$ 7d

2116218

$\mathrm{C}_{14} \mathrm{H}_{28} \mathrm{NiP}_{2}$

317.01

120.15

orthorhombic

$\mathrm{P} 22_{1} 2_{1}$

8.92470(10)

$9.30810(10)$

19.3354(3)

90

90

90

1606.23(4)

4

1.311

3.436

680.0

$0.531 \times 0.321 \times 0.159$

CuKa $(\lambda=1.54184)$

9.148 to 148.026

$-10 \leq h \leq 11,-11 \leq k \leq 10,-23 \leq \mathrm{I} \leq 24$

15137

$3250\left[R_{\text {int }}=0.0196, R_{\text {sigma }}=0.0111\right]$

$3250 / 0 / 159$

1.057

$\mathrm{R}_{1}=0.0417, \mathrm{wR}_{2}=0.1080$

$\mathrm{R}_{1}=0.0417, \mathrm{wR}_{2}=0.1081$

$1.20 /-0.66$ 
Table S3. Crystal structure and data refinement for 9c (CCDC 2116220)

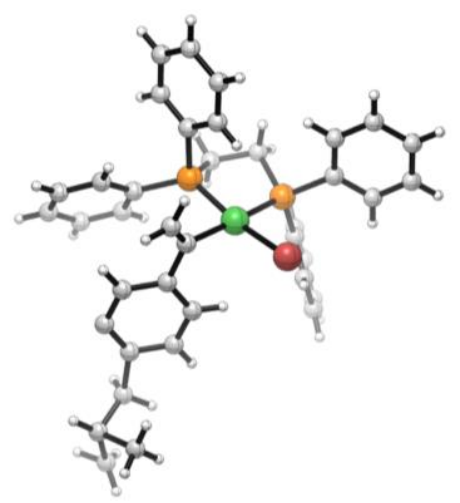

Identification code

CCDC

Empirical formula

Formula weight

Temperature/K

Crystal system

Space group

$\mathrm{a} / \AA$

$\mathrm{b} / \AA ̊ \AA$

$\mathrm{c} / \AA$

$\alpha /{ }^{\circ}$

$\beta /{ }^{\circ}$

$\mathrm{Y} /{ }^{\circ}$

Volume/ $/ \AA^{3}$

Z

$\rho_{\text {calc }} \mathrm{g} / \mathrm{cm}^{3}$

$\mu / \mathrm{mm}^{-1}$

$F(000)$

Crystal size $/ \mathrm{mm}^{3}$

Radiation

$2 \Theta$ range for data collection $/^{\circ}$

Index ranges

Reflections collected

Independent reflections

Data/restraints/parameters

Goodness-of-fit on $\mathrm{F}^{2}$

Final $R$ indexes [l>=2 $\sigma(I)]$

Final $R$ indexes [all data]

Largest diff. peak/hole / e $\AA^{-3}$ 9c

2116220

$\mathrm{C}_{36} \mathrm{H}_{66} \mathrm{BrNiP}_{2}$

699.44

120.15

trigonal

$\mathrm{R}-3 \mathrm{c}$

29.1304(4)

29.1304(4)

23.2647(3)

90

90

120

$17097.0(5)$

18

1.223

2.906

6750.0

$0.806 \times 0.202 \times 0.18$

CuKa $(\lambda=1.54184)$

8.37 to 147.762

$-35 \leq h \leq 32,-35 \leq k \leq 30,-27 \leq \mathrm{I} \leq 21$

20591

$3767\left[R_{\text {int }}=0.0169, R_{\text {sigma }}=0.0092\right]$

$3767 / 0 / 182$

1.055

$R_{1}=0.0313, w R_{2}=0.0857$

$\mathrm{R}_{1}=0.0319, \mathrm{wR}_{2}=0.0862$

$0.62 /-0.56$ 


\section{References}

${ }^{1}$ Krasovskiy, A.; Lipshutz, B. H. Ligand Effects on Negishi Couplings of Alkenyl Halides. Org. Lett. 2011, 13, 3818.

2 Lanni, E. L.; Locke, J. R.; Gleave, C. M.; McNeil, A. J. Ligand-Based Steric Effects in NiCatalyzed Chain-Growth Polymerizations Using Bis(bialkylphosphino)ethanes. Macromolecules 2011, 44, 5136.

${ }^{3}$ Gomes, C. S. B.; Costa, S. I.; Silva, L. C.; Jiménez-Tenorio, M.; Valerga, P.; Puerta, M. C.; Gomes, P. T. Cationic R-Substituted-Indenyl Nickel(II) Complexes of Arsine and Stibine Ligands: Synthesis, Characterization, and Catalytic Behavior in the Oligomerization of Styrene. Eur. J. Inorg. Chem. 2018, 2018, 597.

${ }^{4}$ Soicke, A.; Slavov, N.; Neudörfl, J.-M.; Schmalz, H.-G. Metal-Free Intramolecular CarbonylOlefin Metathesis of ortho-Prenylaryl Ketones. Synlett 2011, 17, 2487.

${ }^{5}$ Fiorito, D.; Folliet, S.; Liu, Y.; Mazet, C. A General Nickel-Catalyzed Kumada Vinylation for the Preparation of 2-Substituted 1,3-Dienes. ACS Catal. 2018, 8, 1392.

${ }^{6}$ Zhang, Y.; Li, J.; Li, X.; He, J. Regio-specific polyacetylenes synthesized from anionic polymerizations of template monomers. Macromolecules 2014, 47, 6260.

7 (a) Burés, J. Variable Time Normalization Analysis: General Graphical Elucidation of Reaction Orders from Concentration Profiles. Angew. Chem. Int. Ed. 2016, 55, 16084. (b) Burés, J. Variable Time Normalization Analysis: General Graphical Elucidation of Reaction Orders from Concentration Profiles. Angew. Chem. Int. Ed. 2016, 55, 16084. (c) Nielsen, C. D.-T.; Burés, J. Visual Kinetic Analysis. Chem. Sci. 2019, 10, 348. 
11. NMR spectra 


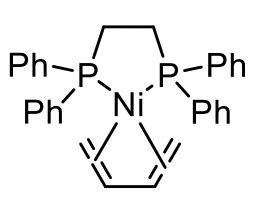

6c

${ }^{1} \mathrm{H}$ NMR $\left(500 \mathrm{MHz}, \mathrm{THF}-\mathrm{d}_{8}, 298 \mathrm{~K}\right)$

$6 c$

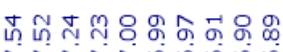

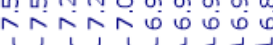

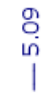

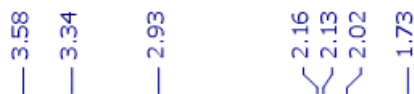

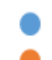

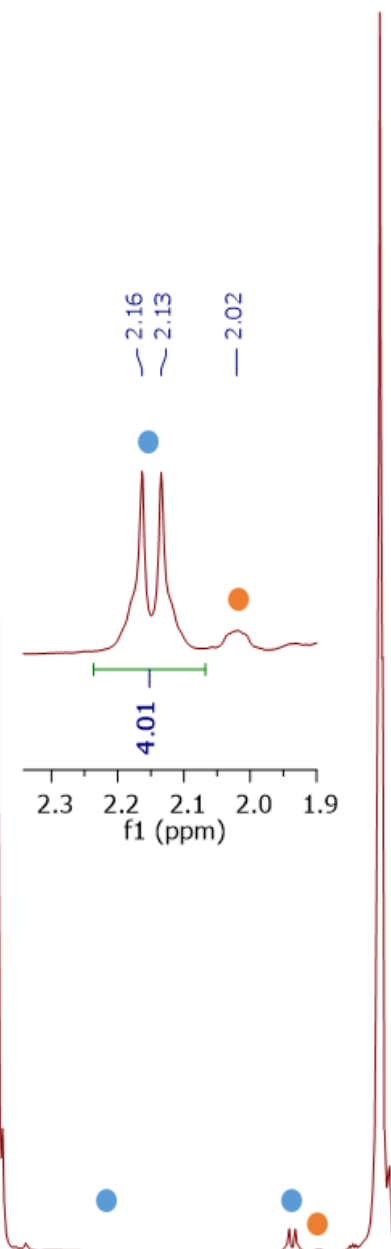

$\mapsto$

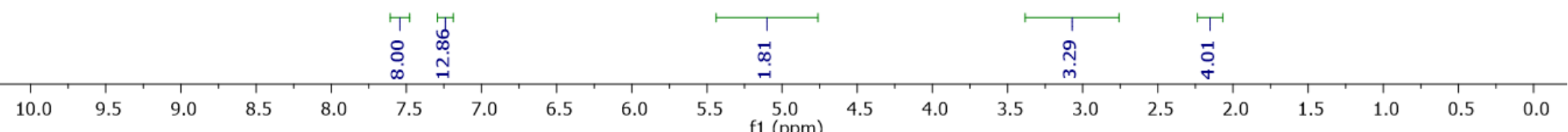




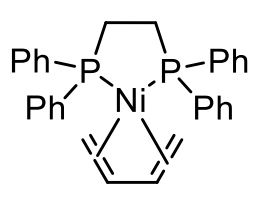

6c

${ }^{13} \mathrm{C}\left\{{ }^{1} \mathrm{H}\right\}$ NMR $\left(130 \mathrm{MHz}, \mathrm{THF}-\mathrm{d}_{8}, 298 \mathrm{~K}\right)$

$6 \mathrm{c}$

$5 c$
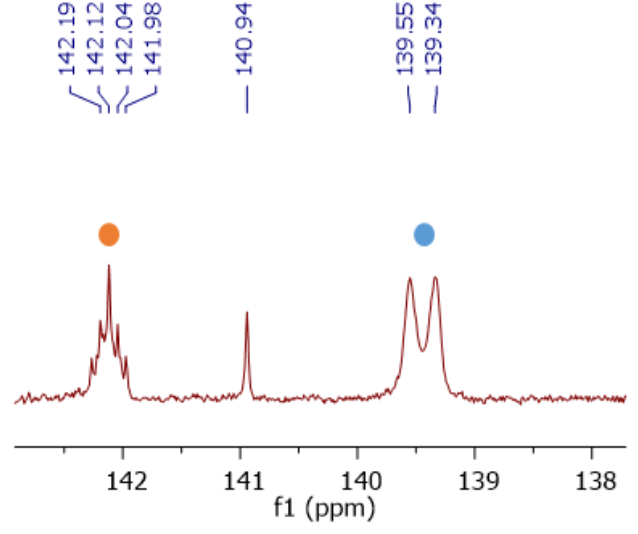

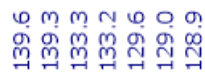

$\rightarrow$

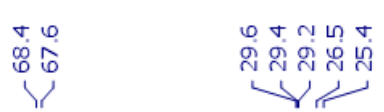

vis

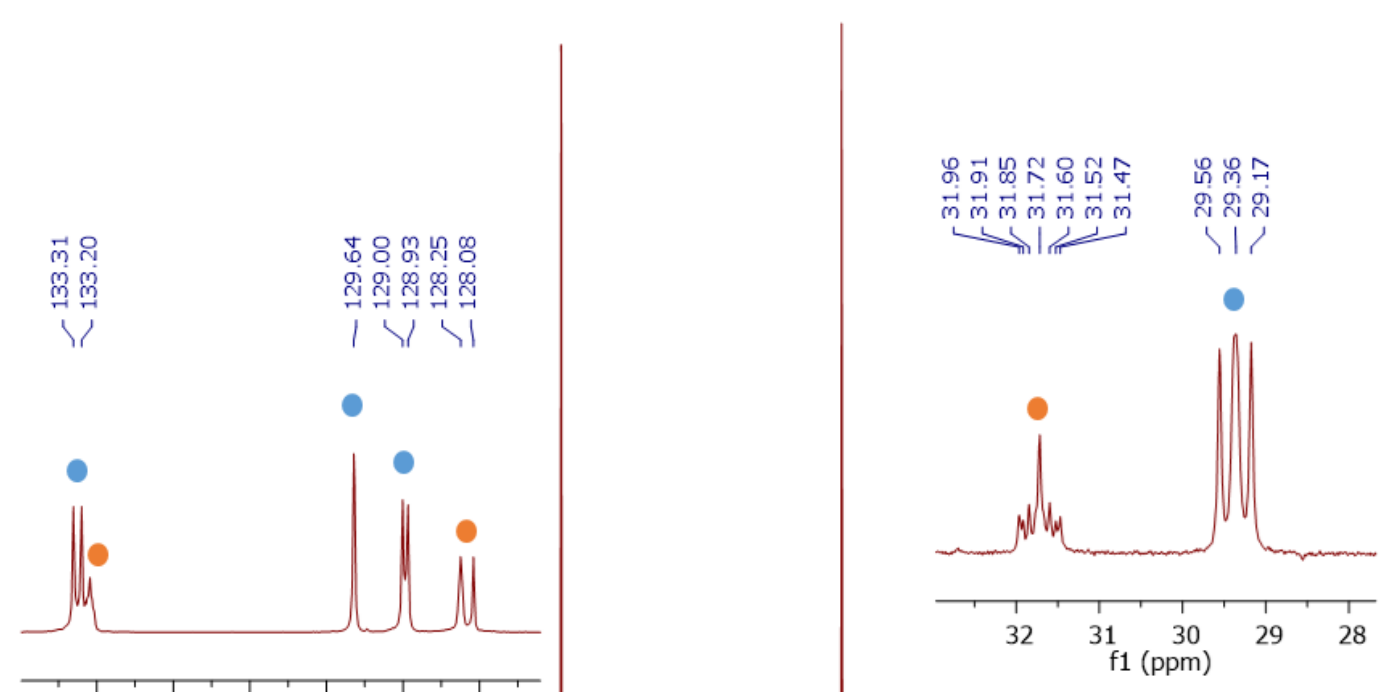

$\begin{array}{lllll}133 & 132 & \begin{array}{lll}131 & 130 \\ \mathrm{f} 1(\mathrm{ppm})\end{array} & 129 & 128\end{array}$
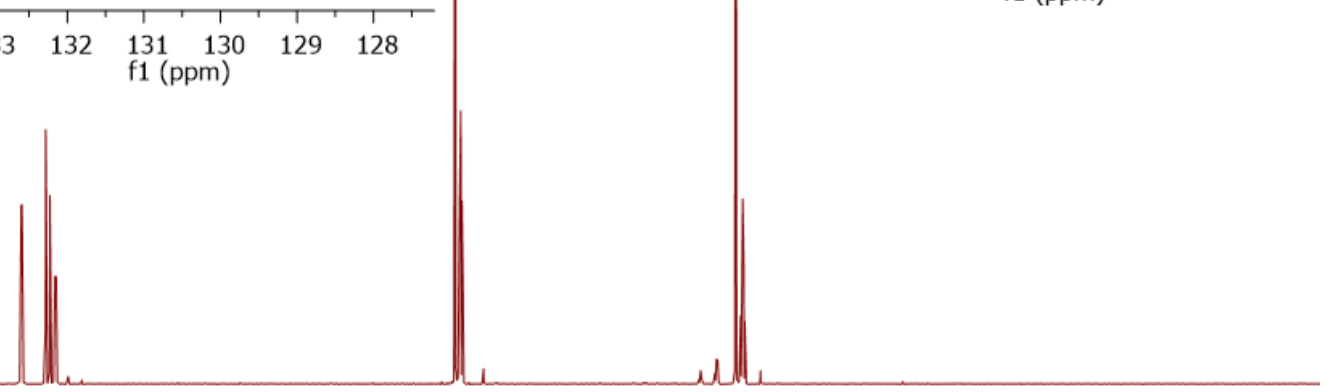

$\begin{array}{llllllllllllllllllllllllllllllllllllllllllllllllllll}260 & 250 & 240 & 230 & 220 & 210 & 200 & 190 & 180 & 170 & 160 & 150 & 140 & 130 & 120 & 110 & 100 & 90 & 80 & 70 & 60 & 50 & 40 & 30 & 20 & 10 & 0 & -10 & -20 & -30 & -40 & -50 & -6\end{array}$ 11 (ppm) 


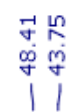

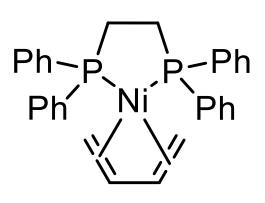

6c

${ }^{31} \mathrm{P}\left\{{ }^{1} \mathrm{H}\right\}$ NMR $\left(160 \mathrm{MHz}, \mathrm{THF}-d_{8}, 298 \mathrm{~K}\right)$

$6 c$

$5 c$
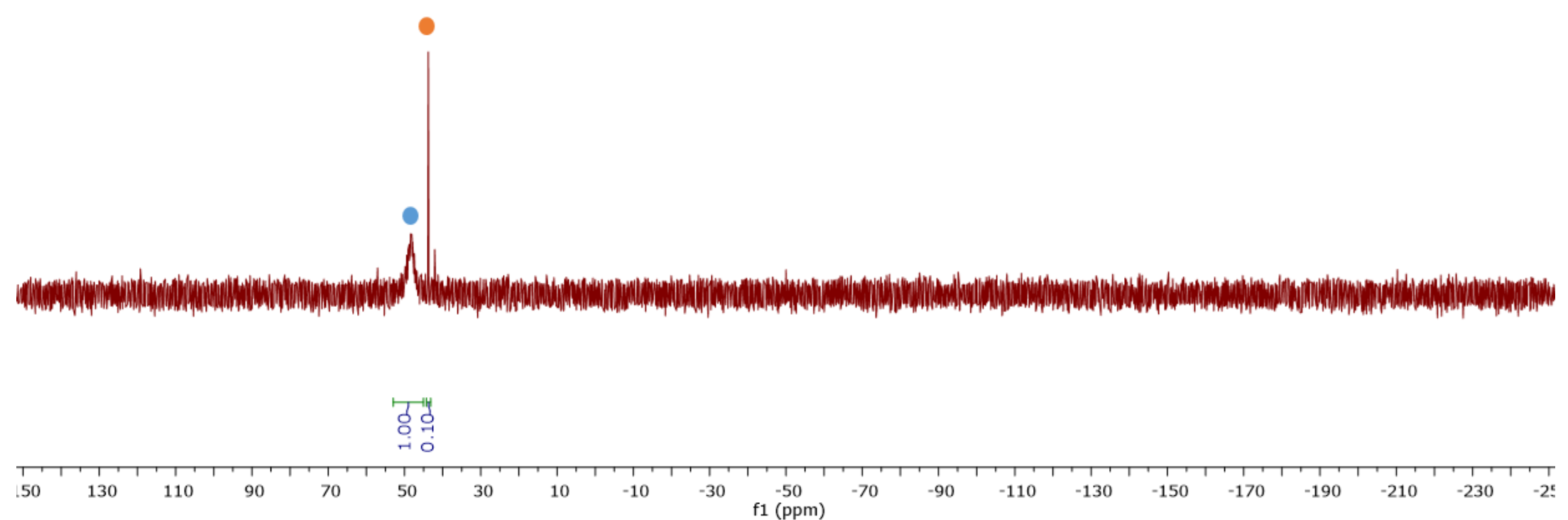


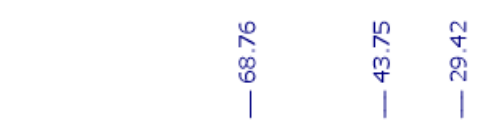

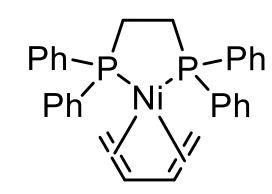

6c

${ }^{31} \mathrm{P}\left\{{ }^{1} \mathrm{H}\right\}$ NMR $\left(160 \mathrm{MHz}, \mathrm{THF}-\mathrm{d}_{8}, 173 \mathrm{~K}\right)$

${ }_{5 \mathrm{c}}^{6 \mathrm{c}}$
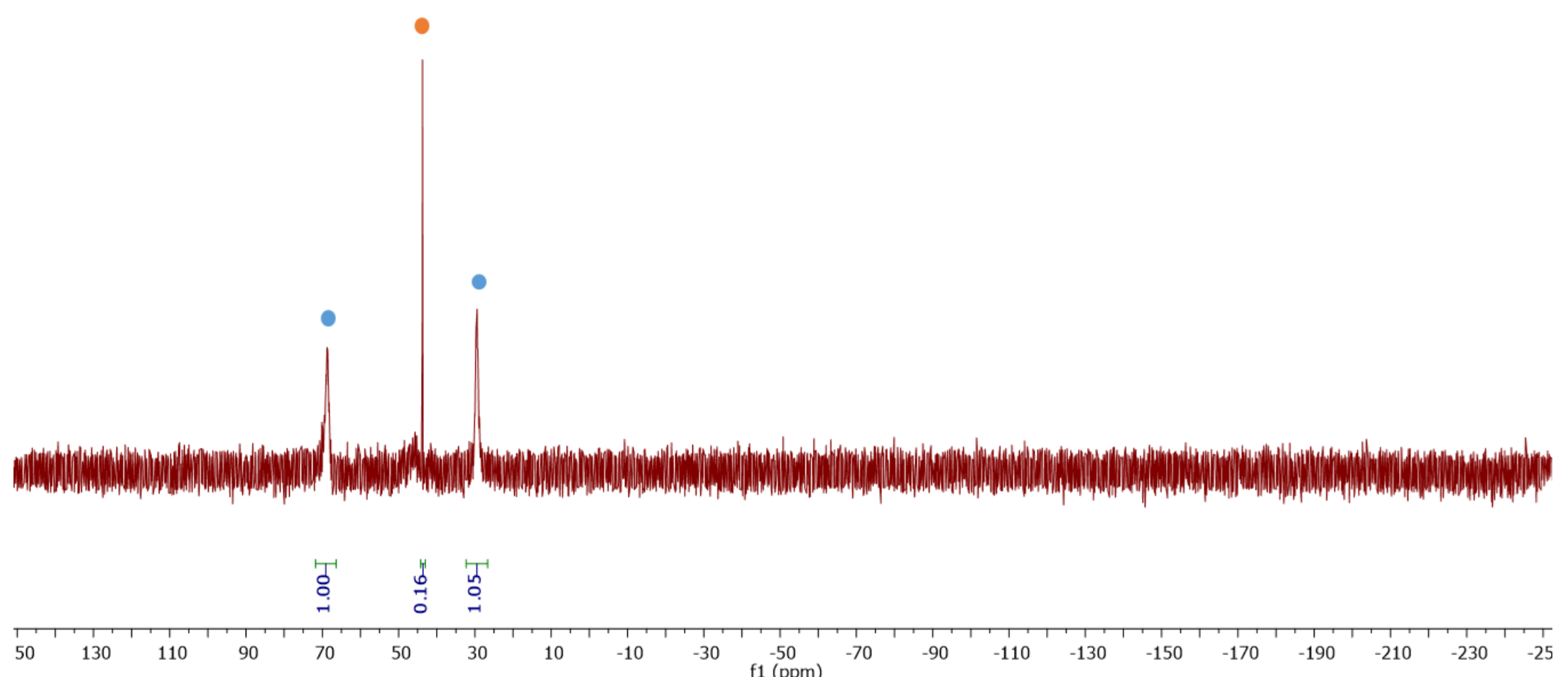


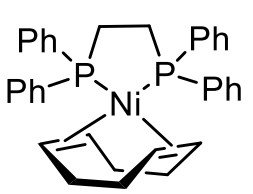

7c

${ }^{1} \mathrm{H}$ NMR $\left(500 \mathrm{MHz}, \mathrm{THF}-d_{8}, 298 \mathrm{~K}\right)$

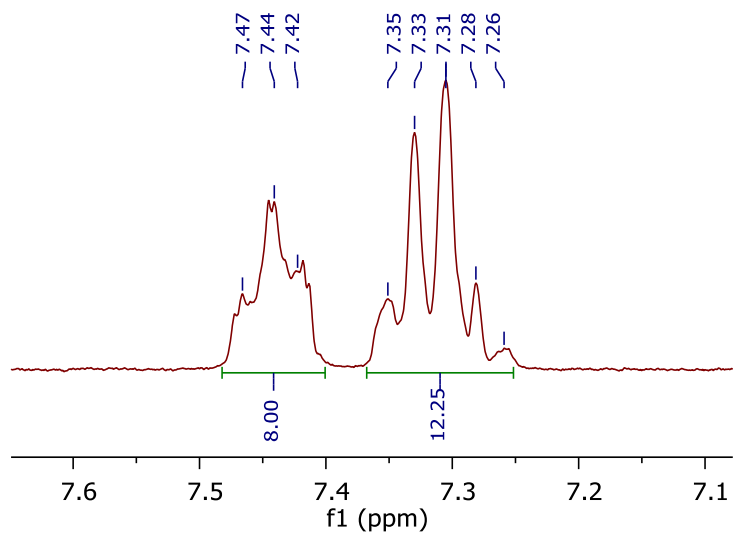

f 车 궀

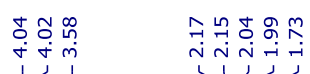

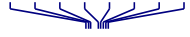

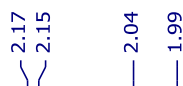
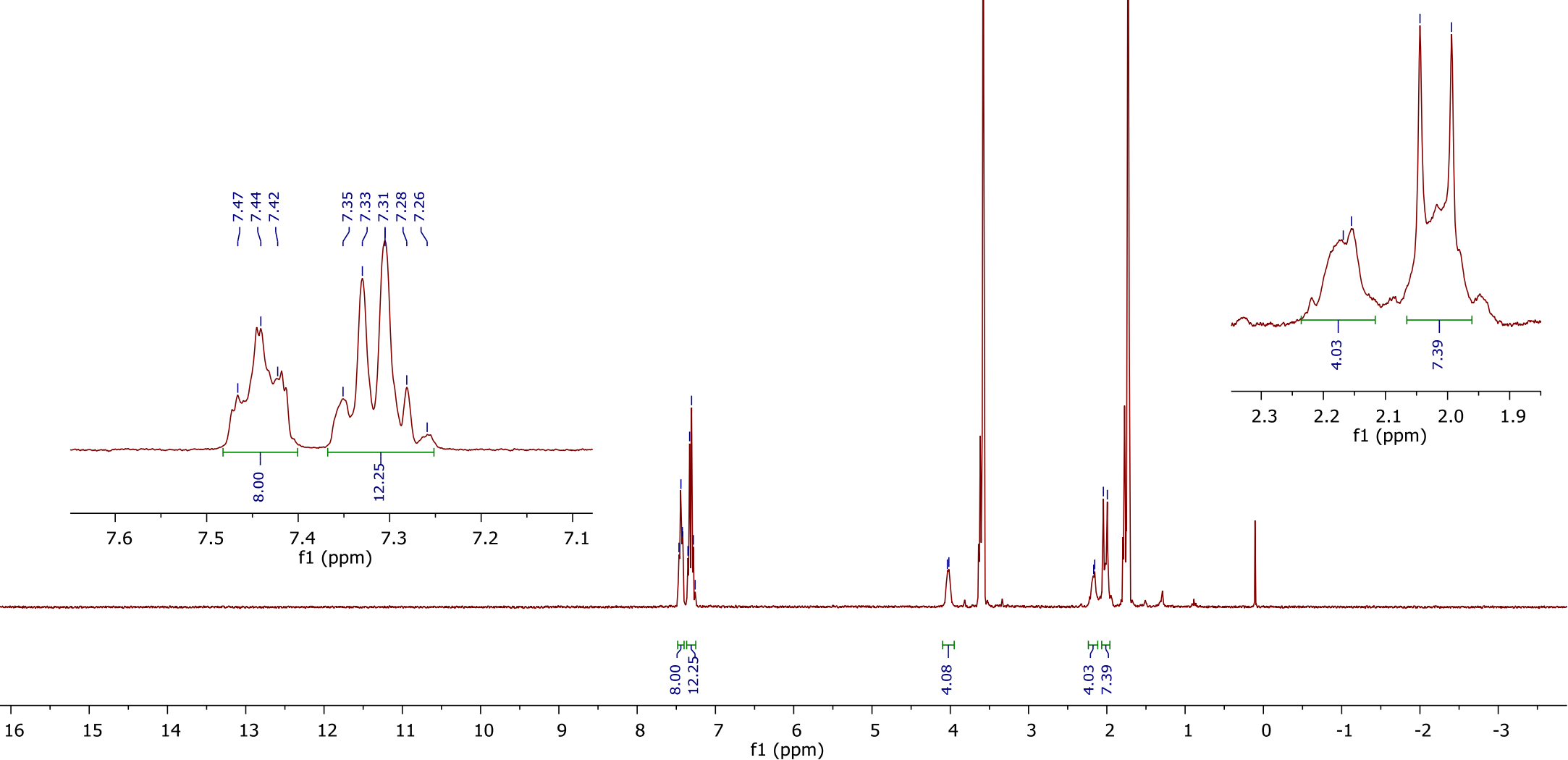


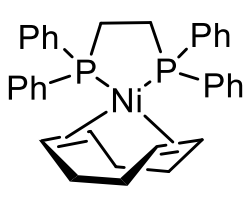

$7 c$

${ }^{13} \mathrm{C}\left\{{ }^{1} \mathrm{H}\right\}$ NMR $\left(130 \mathrm{MHz}\right.$, THF- $\left.d_{8}, 298 \mathrm{~K}\right)$
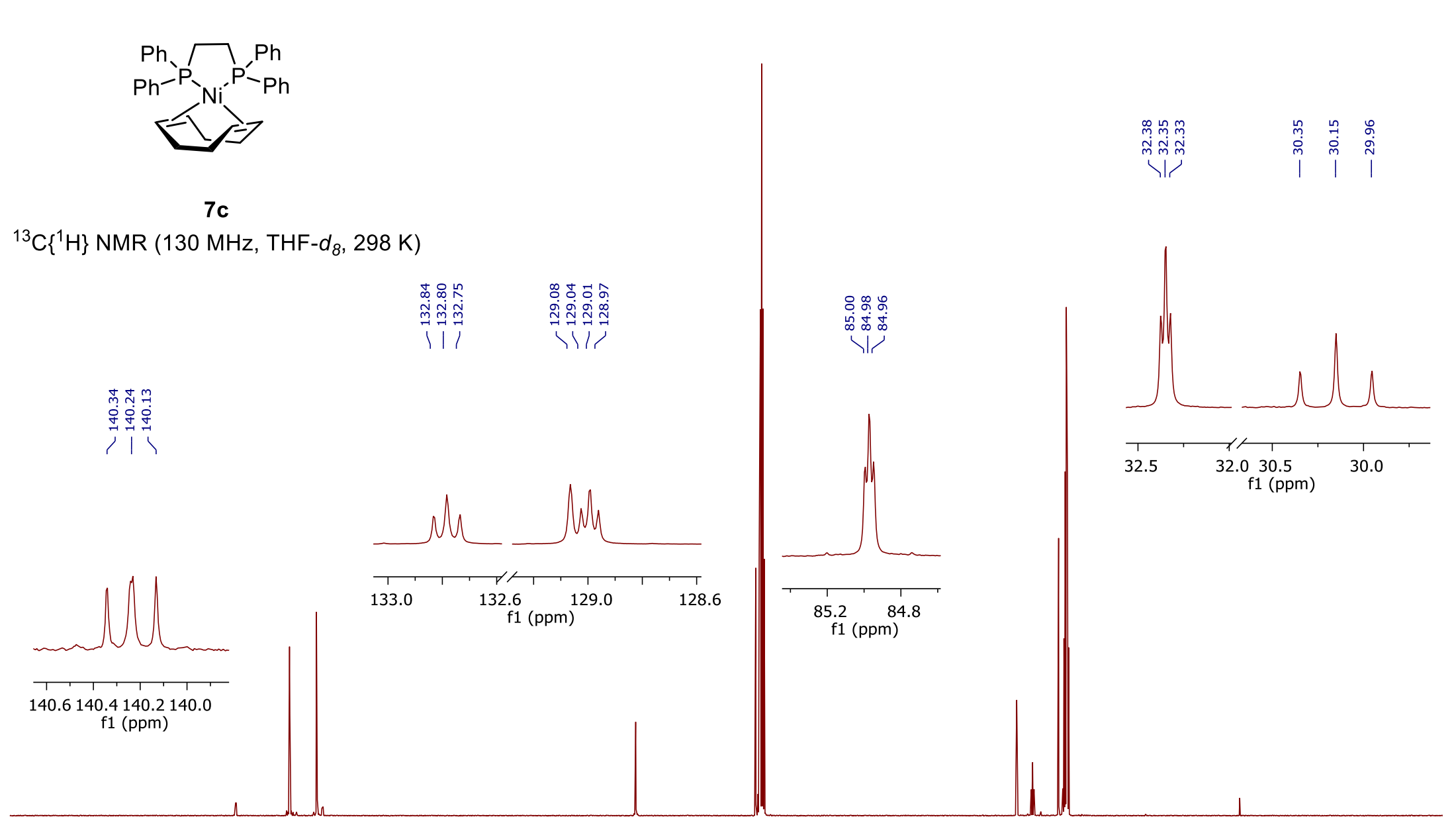

ॠنं

$\forall$

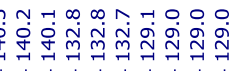

$\forall$

ํํㅇํํ

il

\section{(1)}

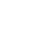

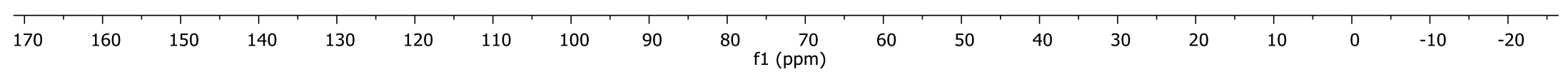




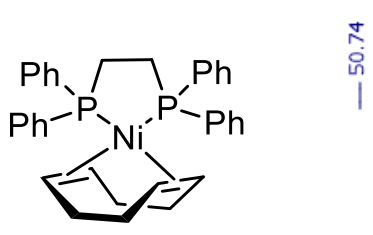

$7 c$

${ }^{31} \mathrm{P}\left\{{ }^{1} \mathrm{H}\right\}$ NMR $\left(160 \mathrm{MHz}, \mathrm{THF}-\mathrm{d}_{8}, 298 \mathrm{~K}\right)$

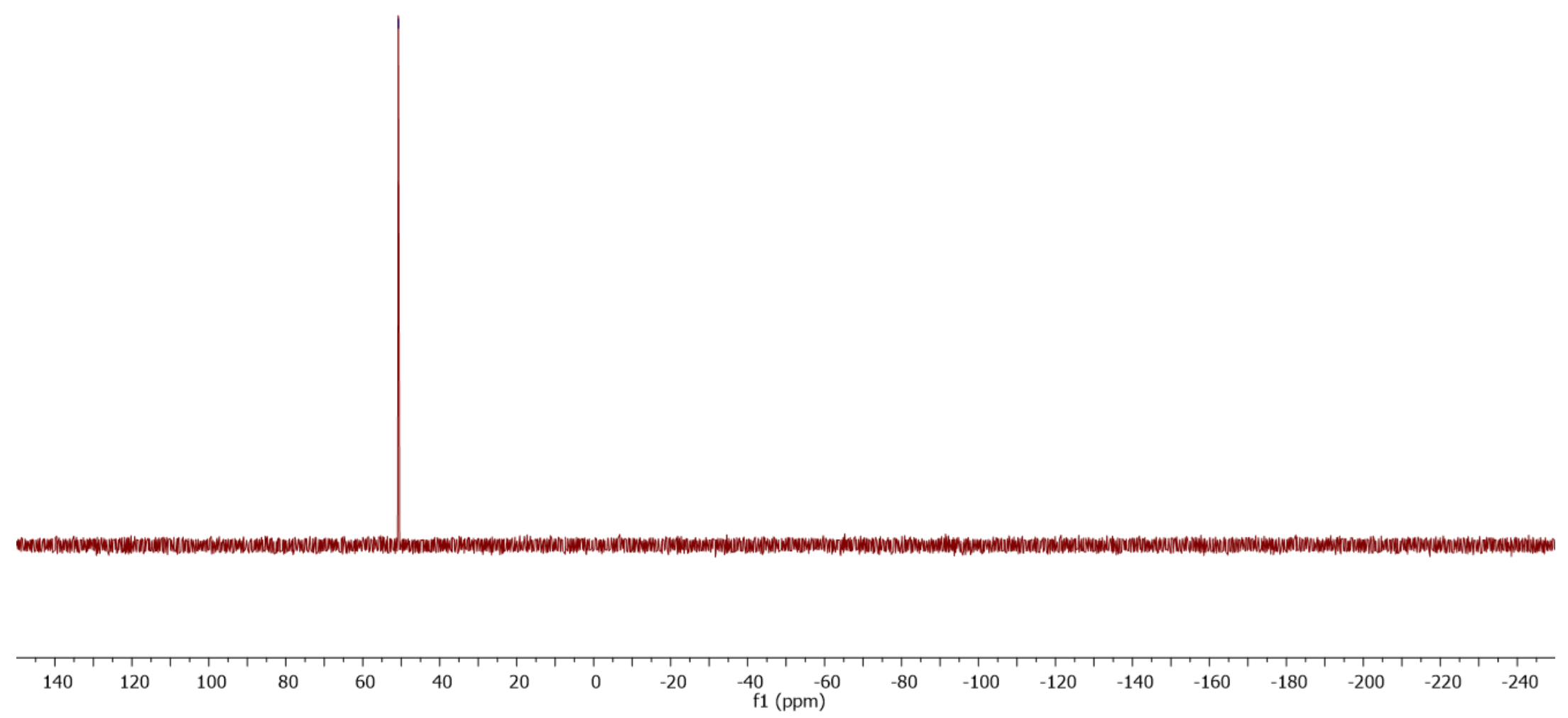




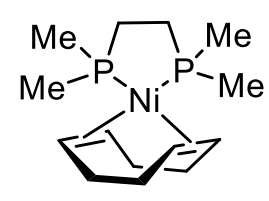

7d

${ }^{1} \mathrm{H}$ NMR $\left(500 \mathrm{MHz}, \mathrm{THF}-\mathrm{d}_{8}, 298 \mathrm{~K}\right)$

i̊n

(ppm)

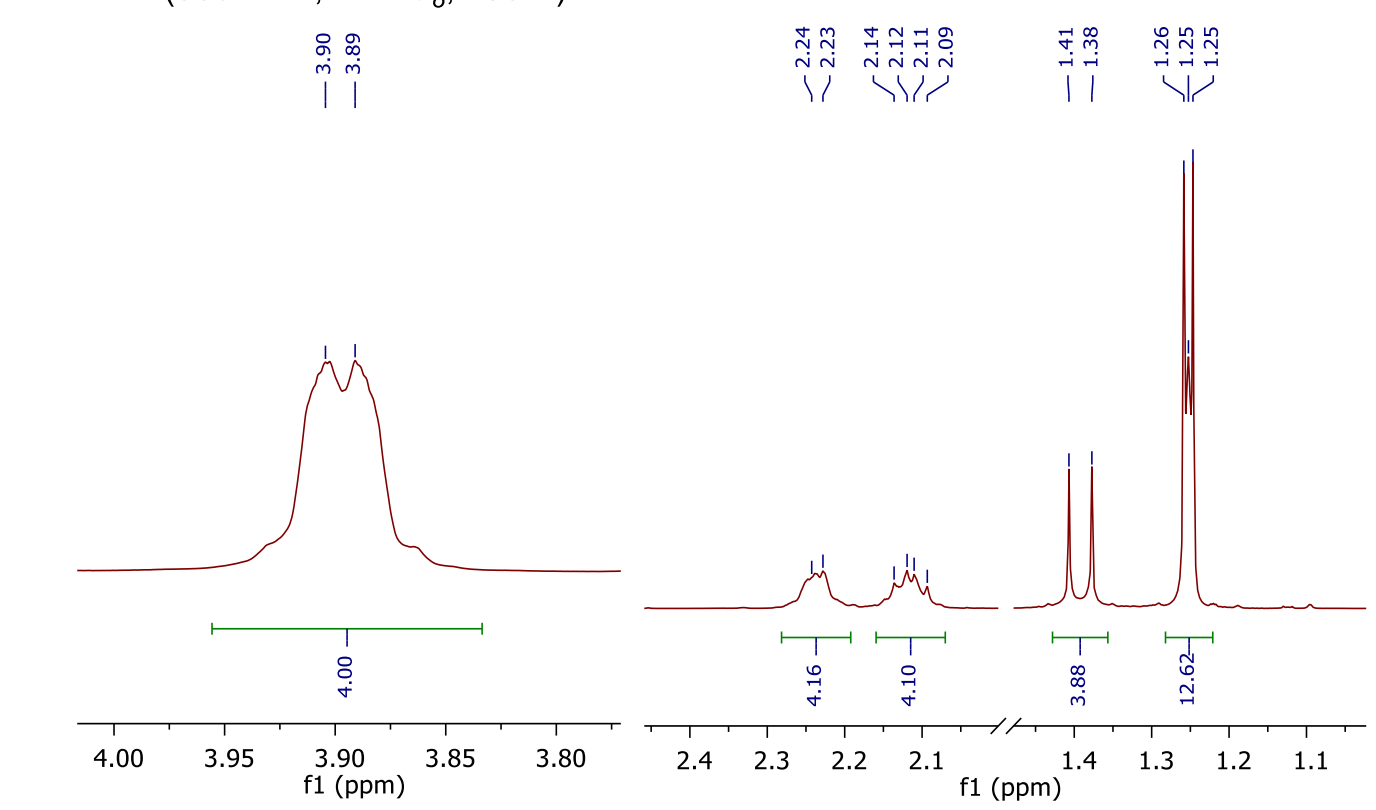

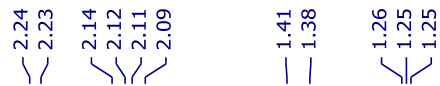

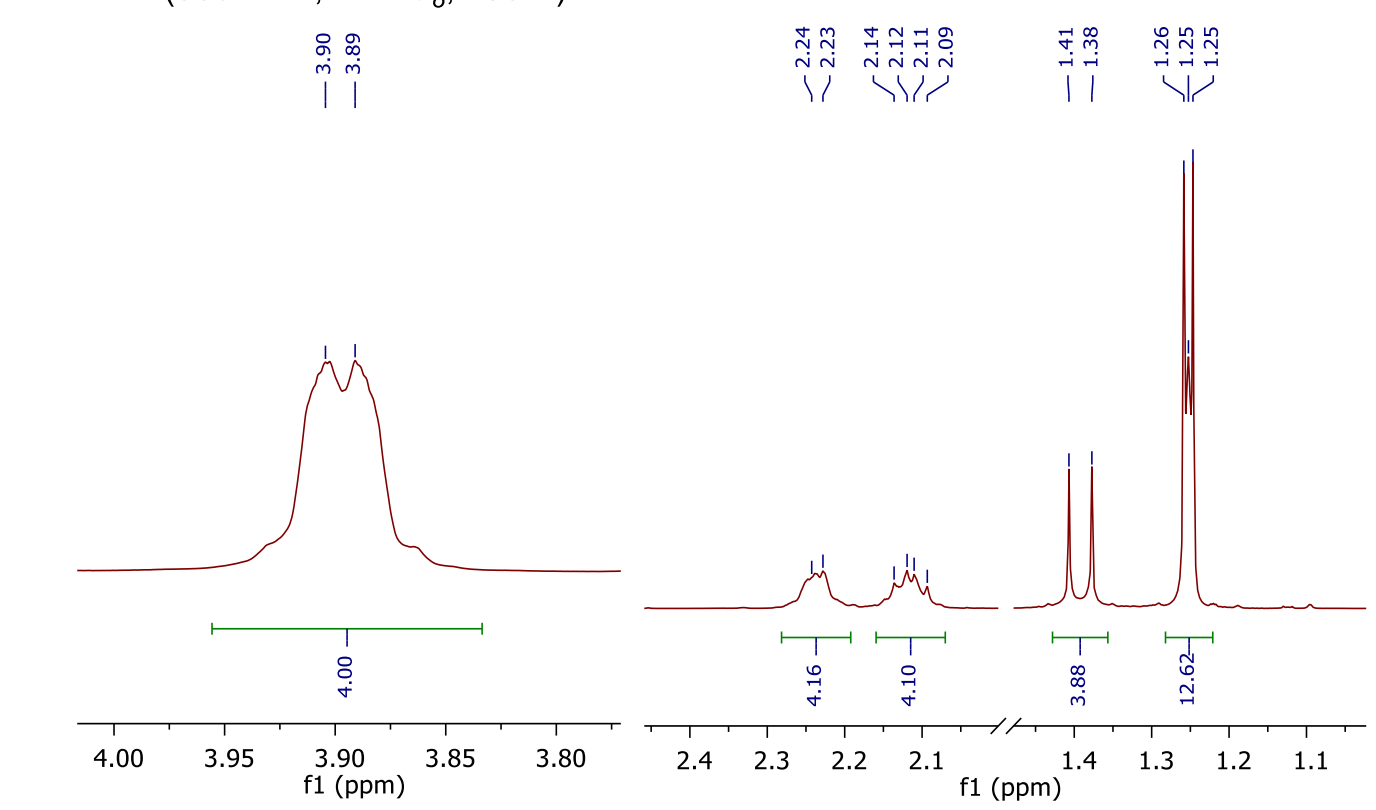

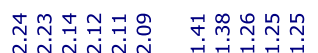

$\stackrel{\circ}{m}_{\substack{\infty \\ m}}^{\infty}$

Nv

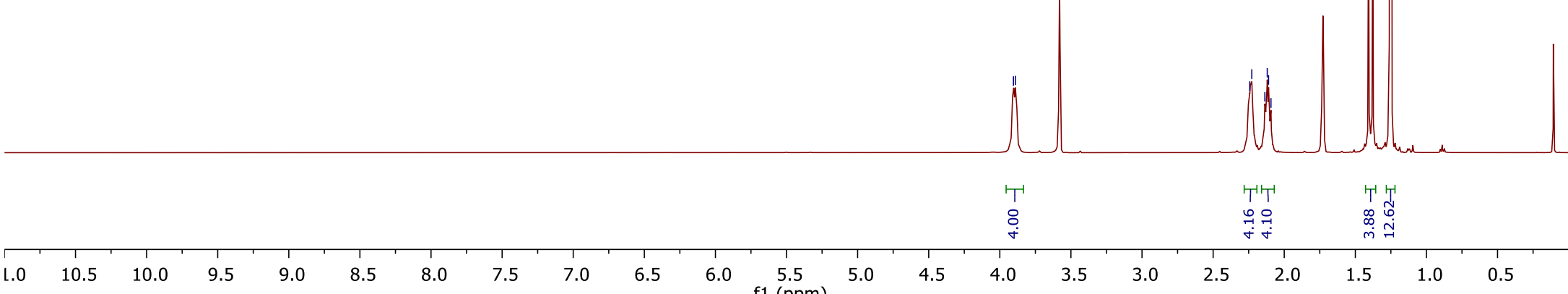




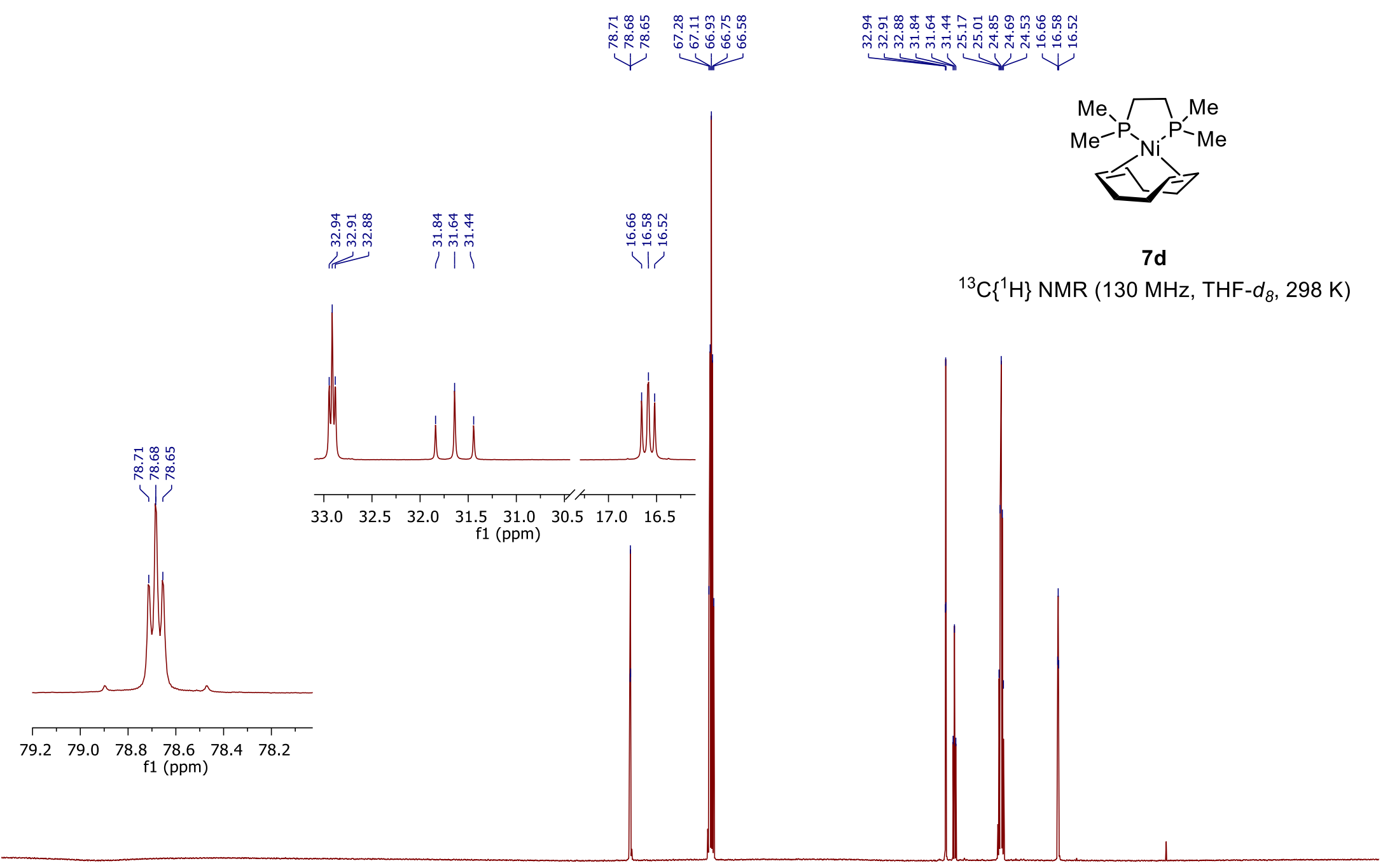




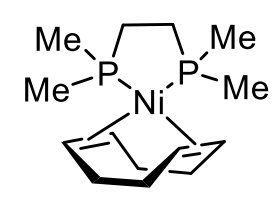

$7 d$

${ }^{31} \mathrm{P}\left\{{ }^{1} \mathrm{H}\right\}$ NMR $\left(160 \mathrm{MHz}, \mathrm{THF}-\mathrm{d}_{8}, 298 \mathrm{~K}\right)$

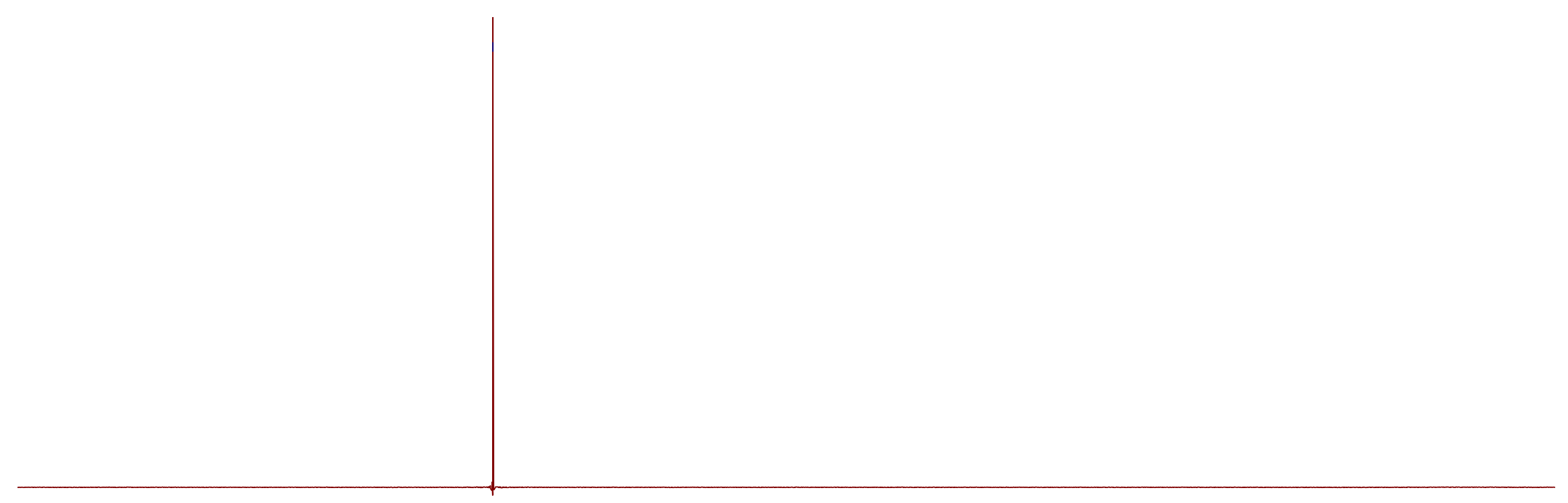

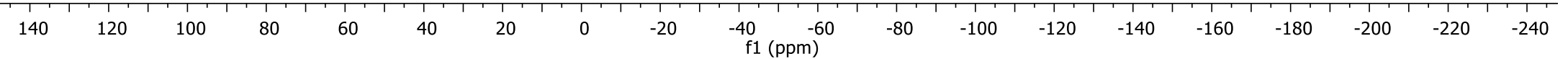




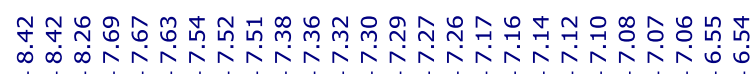

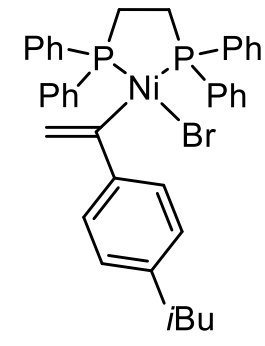

9c

${ }^{1} \mathrm{H}$ NMR (500 MHz, THF- $d_{8}, 243 \mathrm{~K}$ )

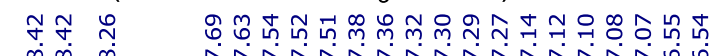

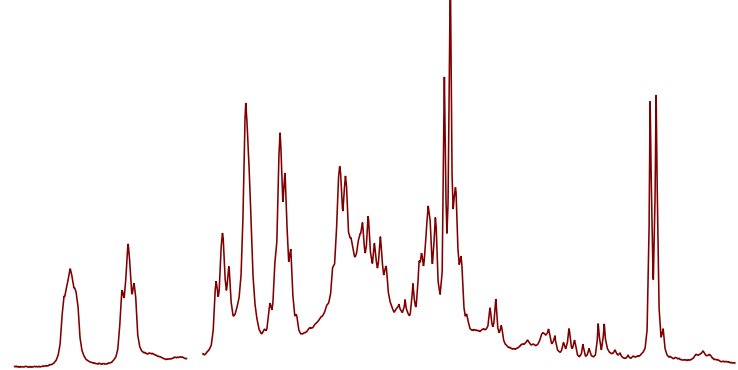

$\mapsto T 14$

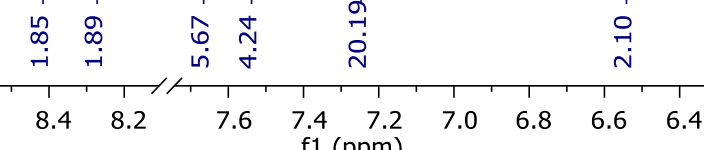

$V_{\infty}^{\infty}$

\section{กุํำ요요}

) 1

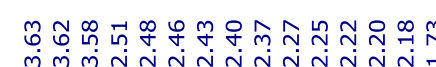

ming

$\bigcup_{\substack{n \\ 0}}^{\substack{a \\ 0}}$

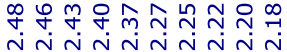

(1)

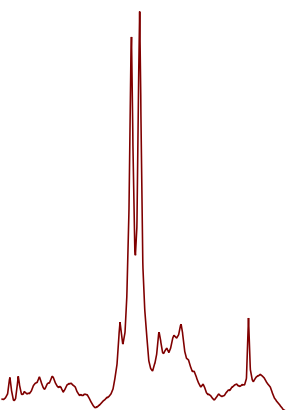

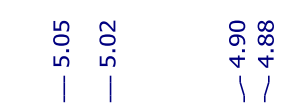

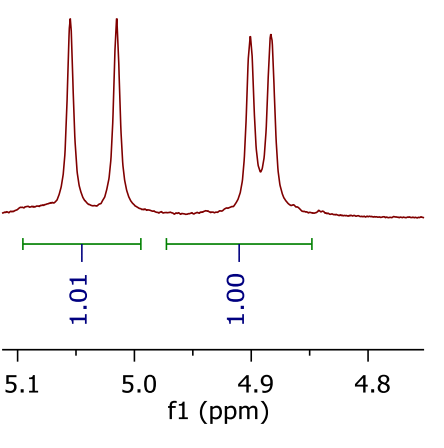

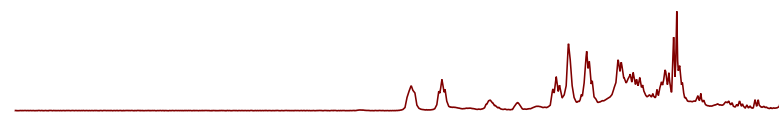

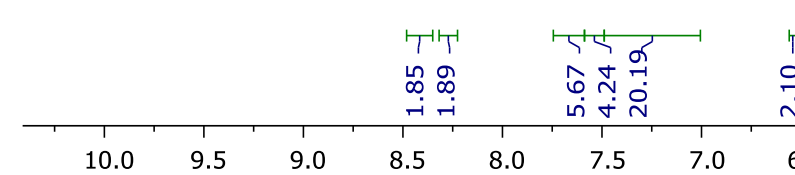

$\mu$

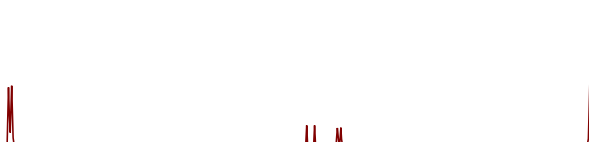

nimenth

Tाए

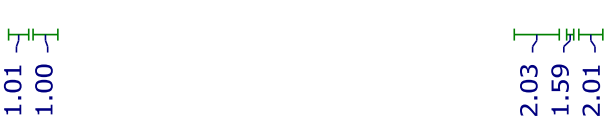

ํํำ ำ

$\longleftarrow$ T'

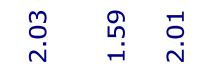

$\begin{array}{llllll}2.4 & 2.3 & 2.2 & 2.1 & 2.0\end{array}$ f1 (ppm)

$\begin{array}{lllllllllll}10.0 & 9.5 & 9.0 & 8.5 & 8.0 & 7.5 & 7.0 & 6.5 & 6.0 & 5.5 & 5.0\end{array}$

f1 5.0 (ppm) 


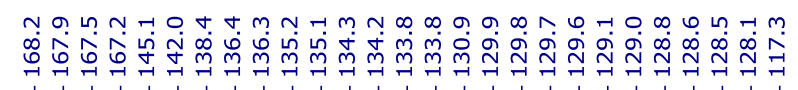

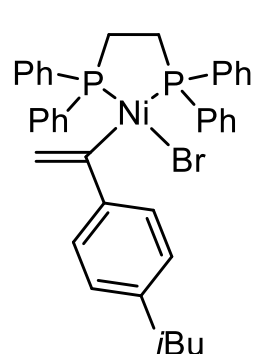

9c

${ }^{13} \mathrm{C}\left\{{ }^{1} \mathrm{H}\right\}$ NMR $\left(130 \mathrm{MHz}, \mathrm{THF}-\mathrm{d}_{8}, 243 \mathrm{~K}\right)$

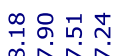

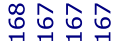

1111

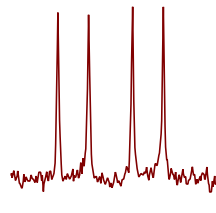

$\begin{array}{rr}168.3 & 167.4\end{array}$

f1 (ppm)

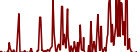

ๆ.

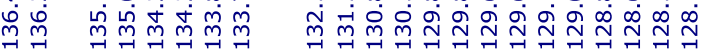

$\checkmark>$

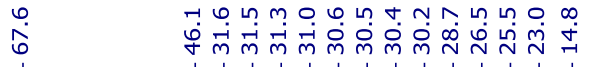

minn

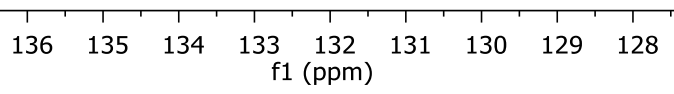

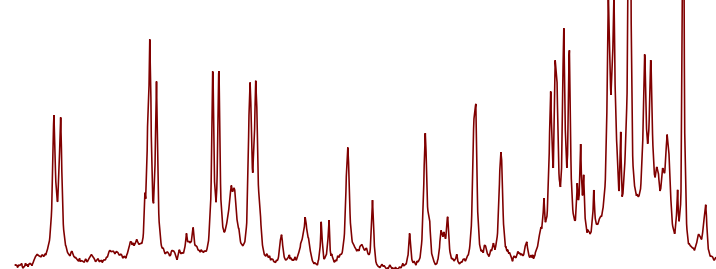




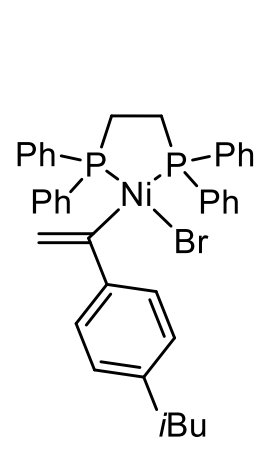

$9 c$

${ }^{31} \mathrm{P}\left\{{ }^{1} \mathrm{H}\right\}$ NMR (160 MHz, THF- $\left.d_{8}, 243 \mathrm{~K}\right)$

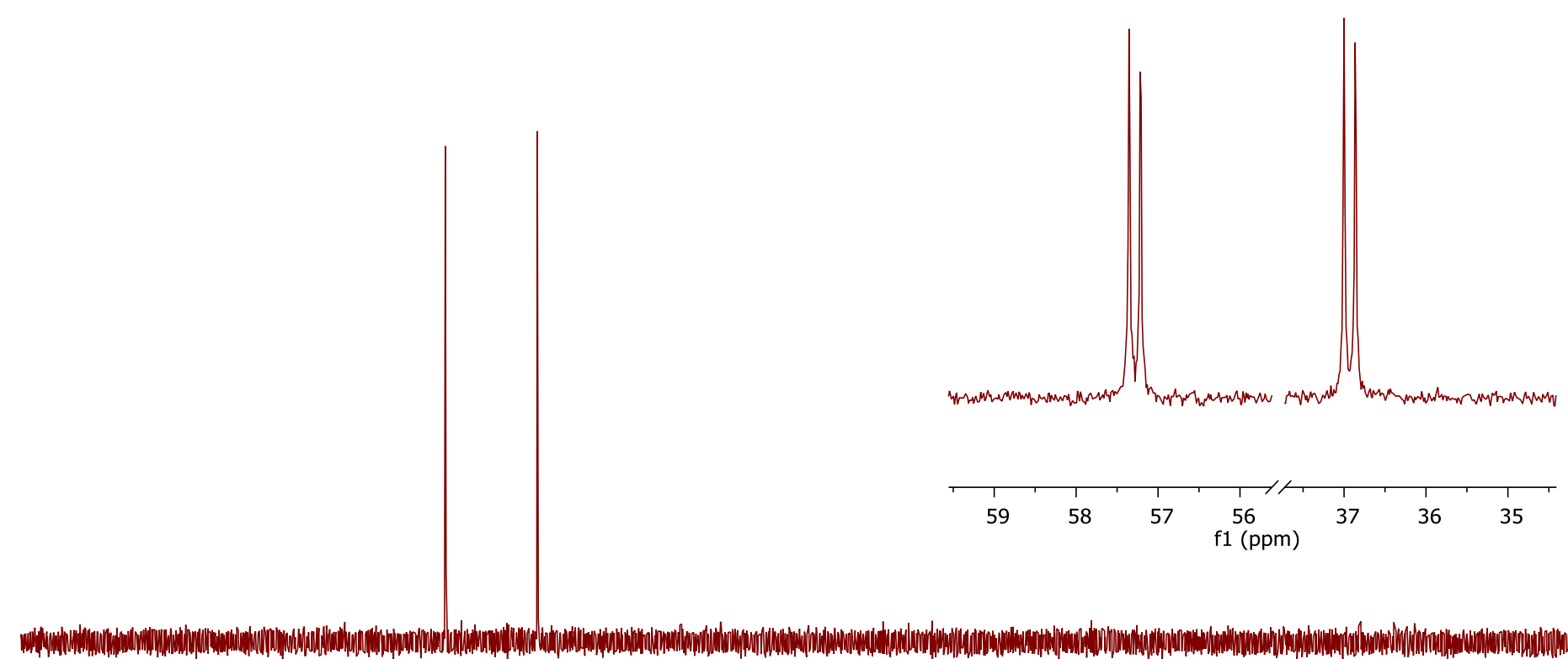

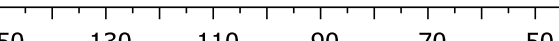

$50 \quad 130$

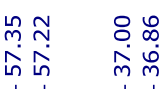

$Y \quad Y$
$110 \quad 90$

$30 \quad 10$

$-30$

f1 $\stackrel{-50}{(\mathrm{ppm})}$
8

ind

$70 \quad 50$ 


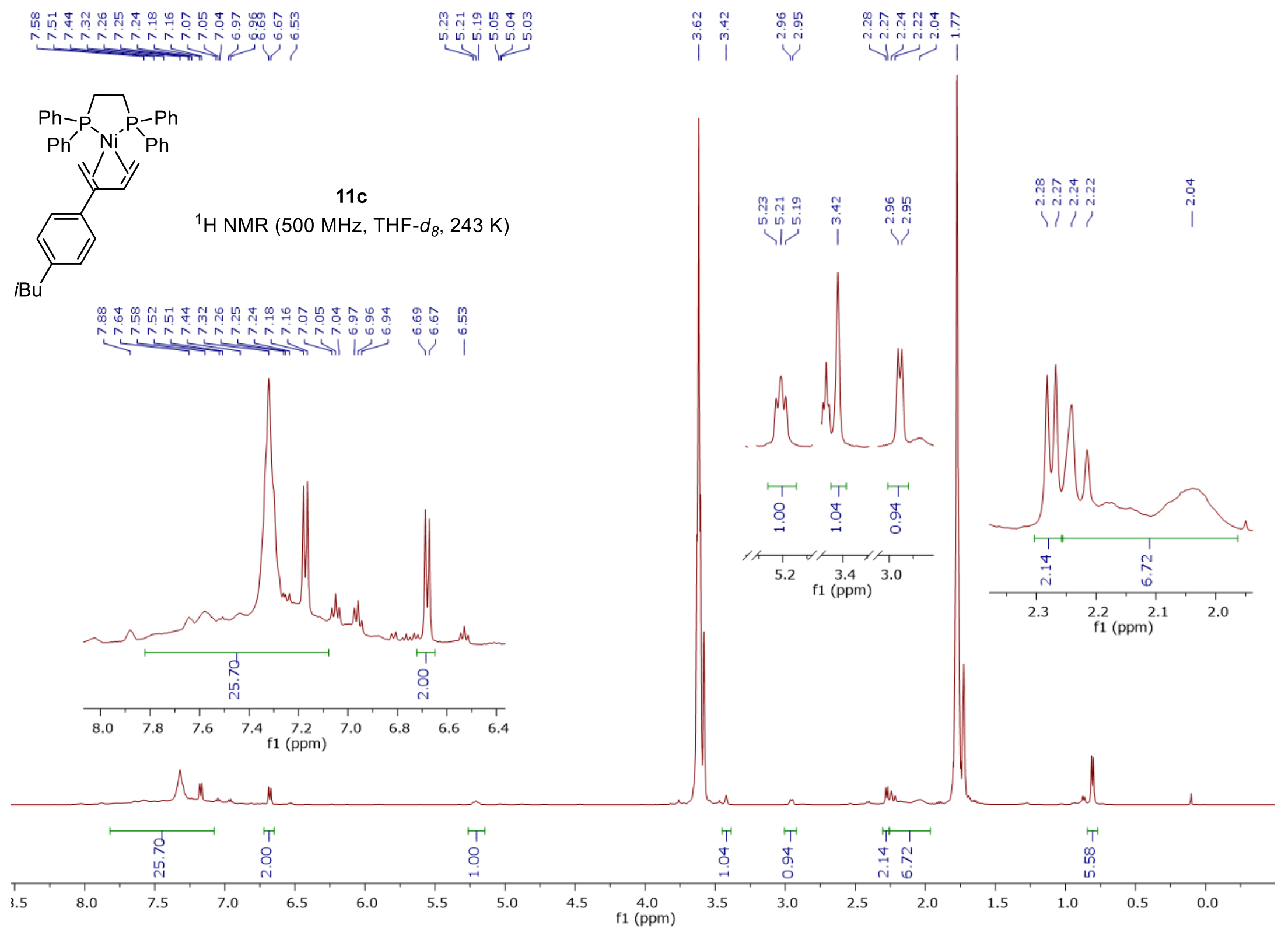




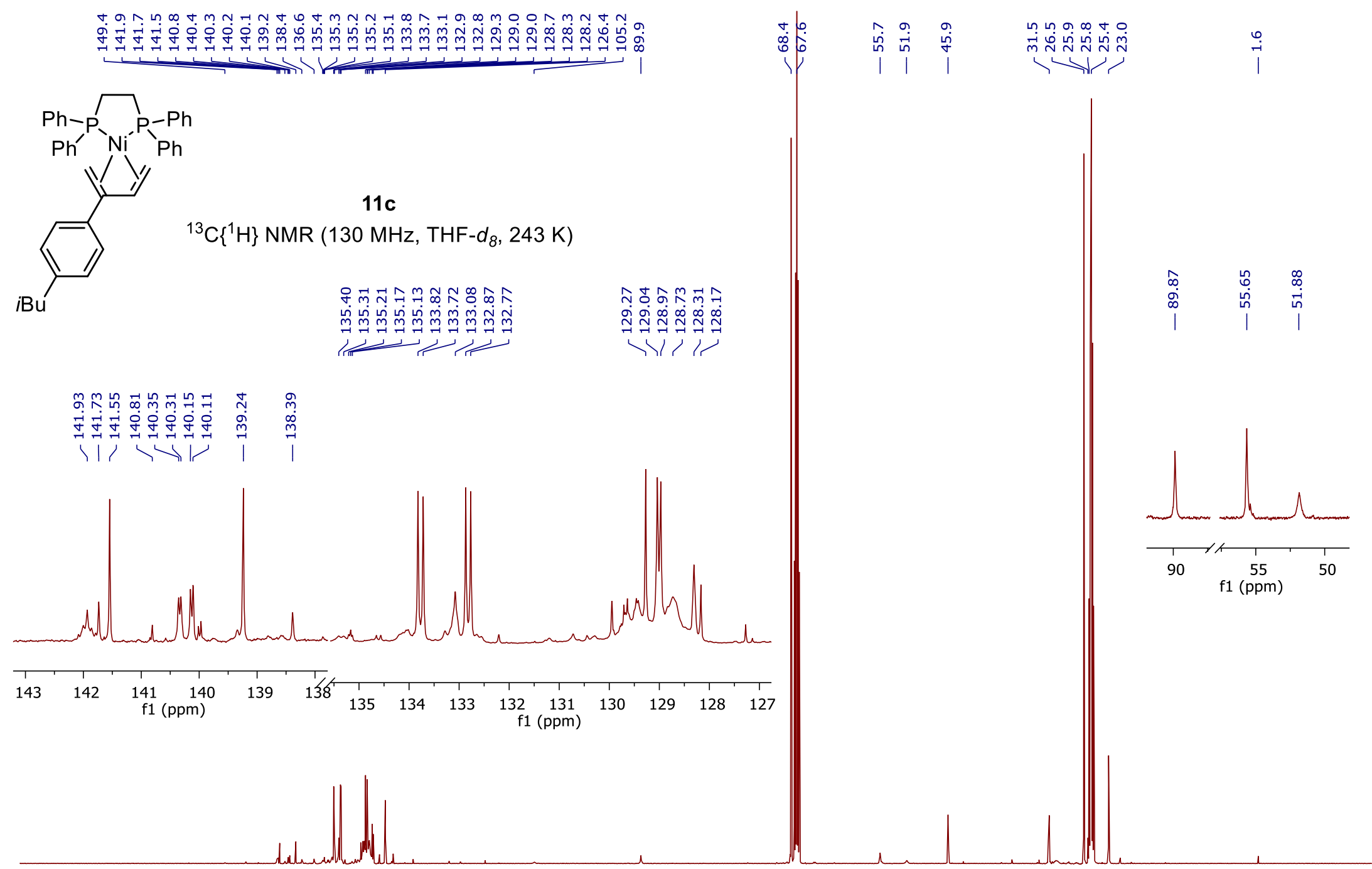

$170 \quad 160$ 
$11 \mathrm{c}$
$\mathrm{P}\left\{{ }^{1} \mathrm{H}\right\} \mathrm{NMR}\left(160 \mathrm{MHz}, \mathrm{THF}-\mathrm{d}_{8}, 243 \mathrm{~K}\right)$

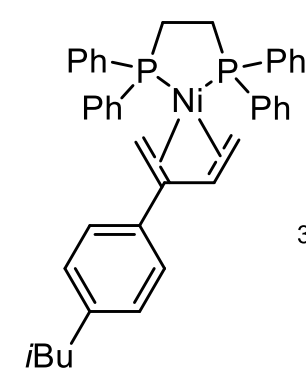

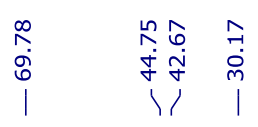
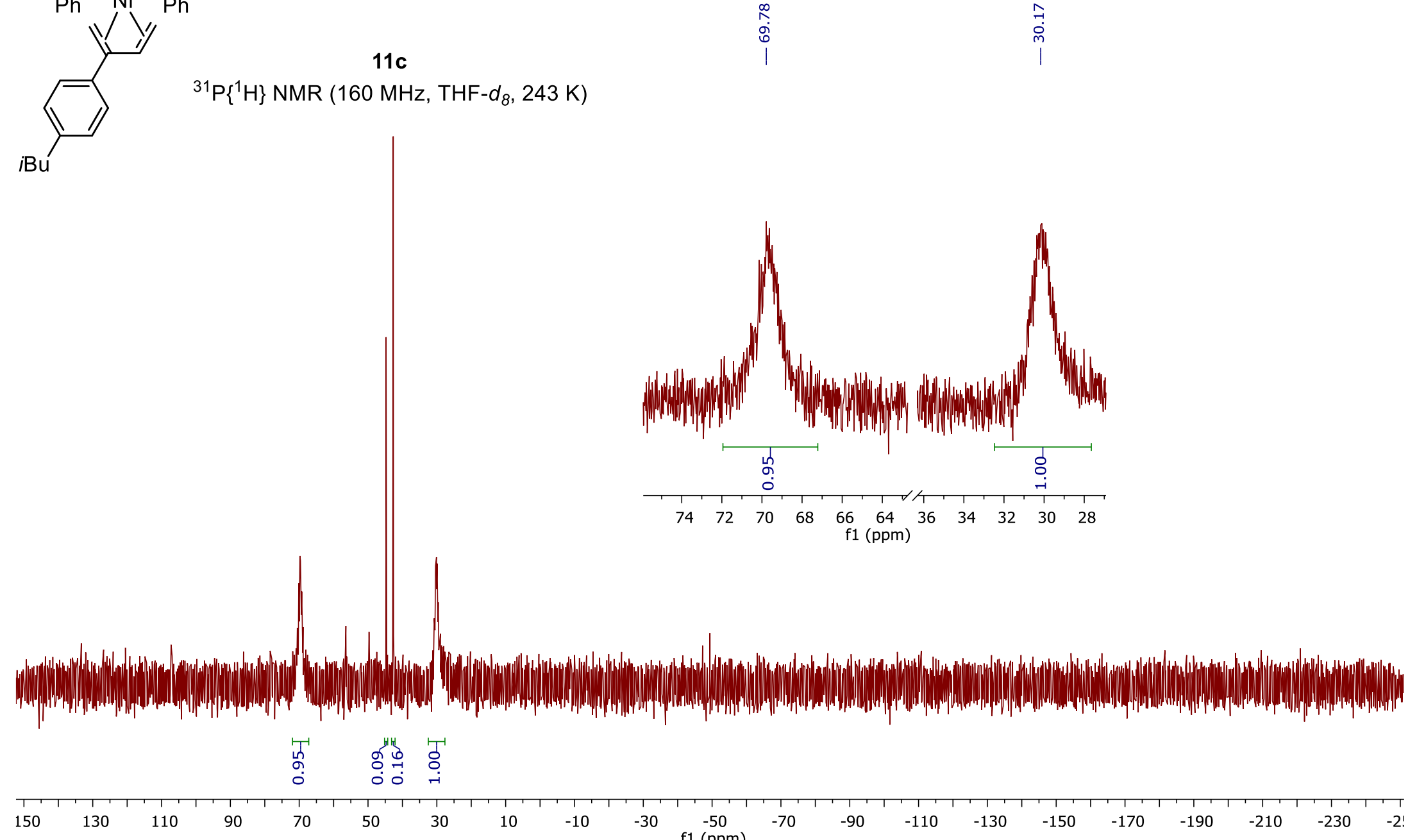

${ }^{1}\left\{{ }^{1} H\right\}$ NMR $\left(160 \mathrm{MHz}\right.$, THF- $\left.d_{8}, 243 \mathrm{~K}\right)$ 


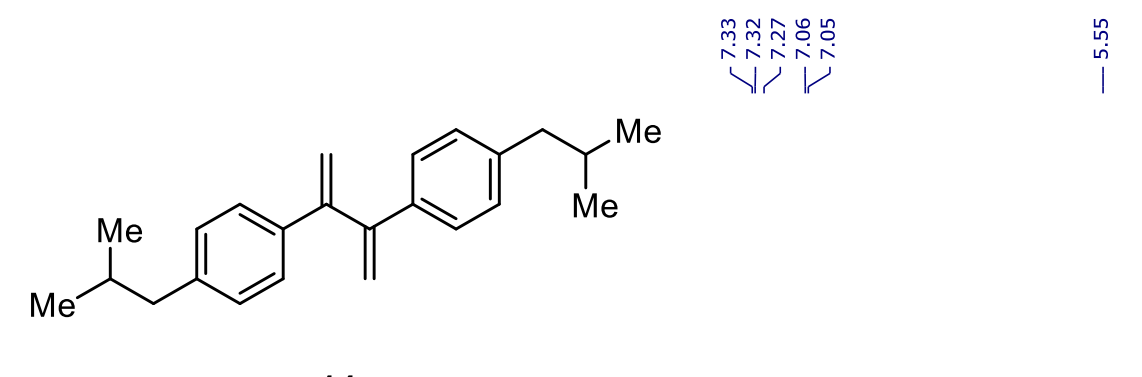

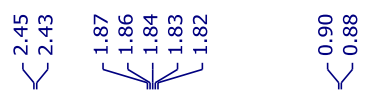

14

${ }^{1} \mathrm{H}$ NMR $\left(500 \mathrm{MHz}, \mathrm{CDCl}_{3}, 298 \mathrm{~K}\right)$

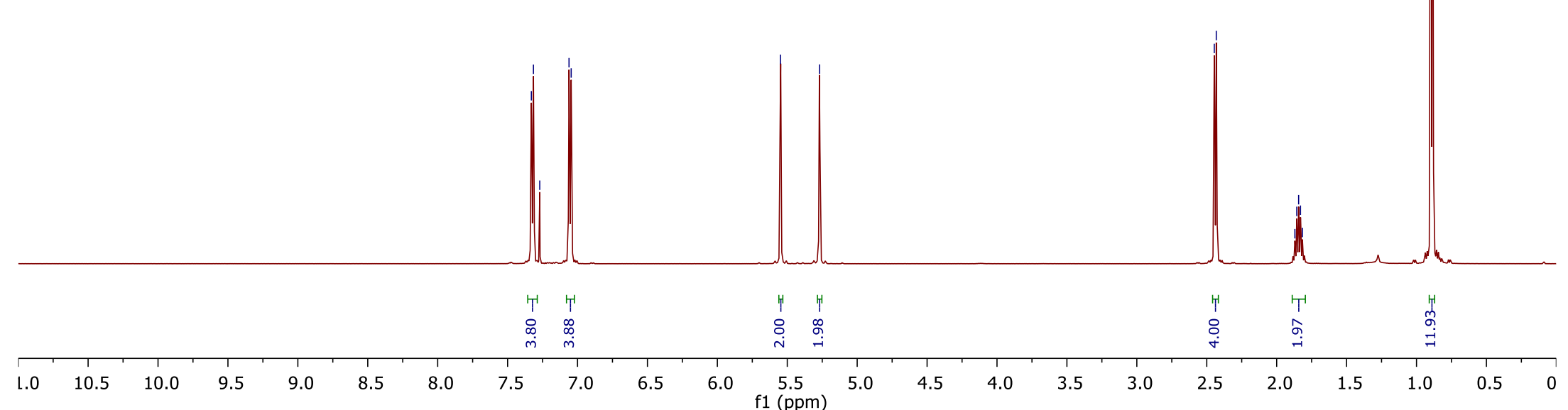




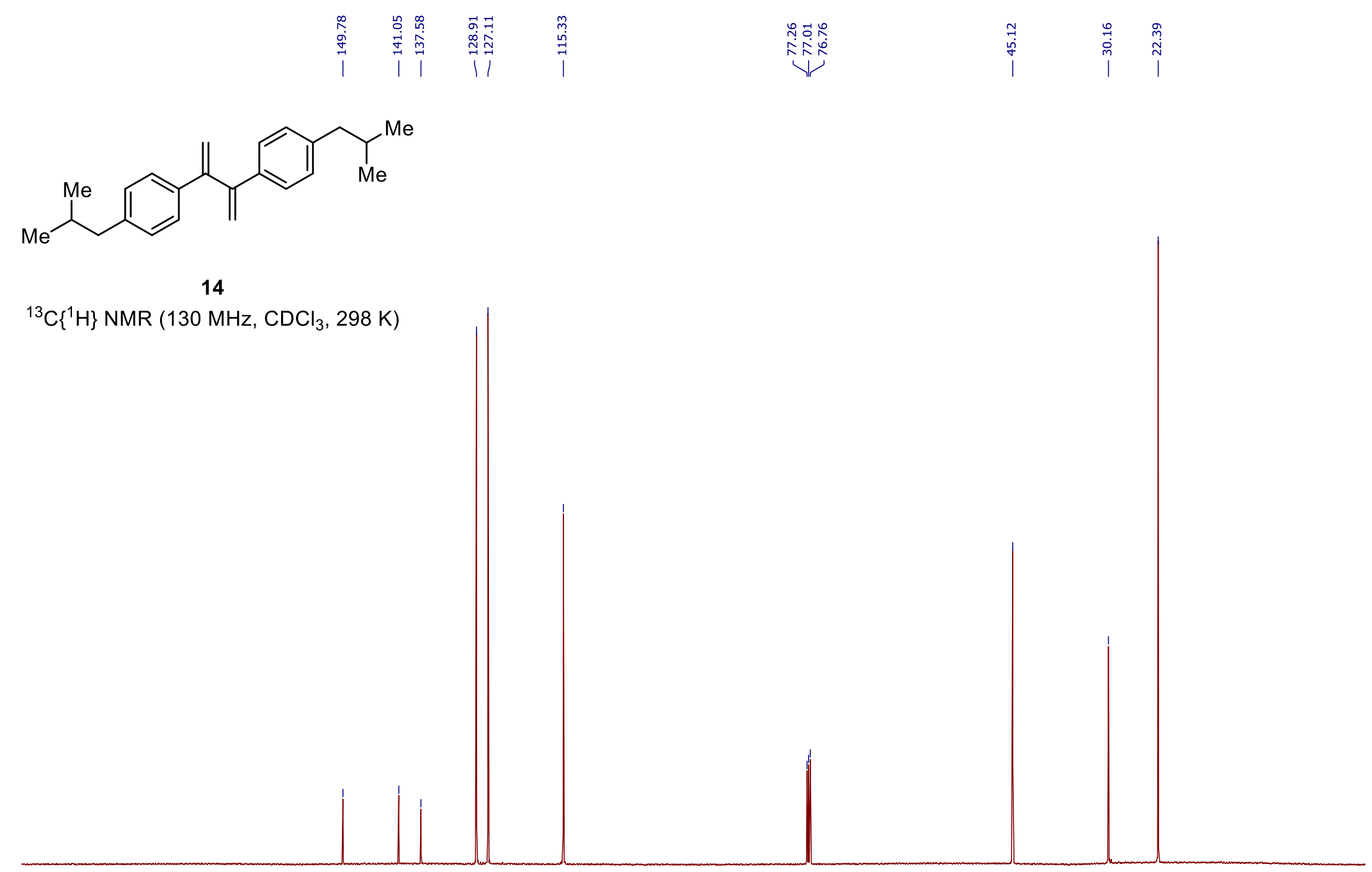


סำ

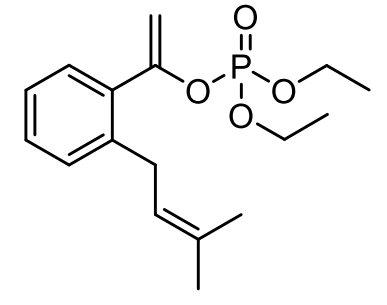

$1 \mathrm{~g}$

${ }^{1} \mathrm{H} \mathrm{NMR}\left(500 \mathrm{MHz}, \mathrm{CDCl}_{3}, 298 \mathrm{~K}\right)$

חֻ

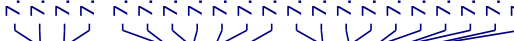

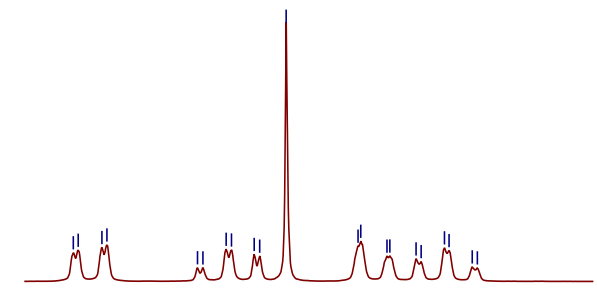
$\begin{array}{llllll}7.40 & 7.35 & 7.30 & 7.25 & 7.20 & 7.15\end{array}$

L.0 $\quad 10.5$

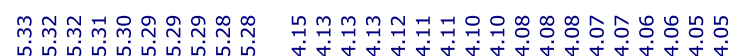
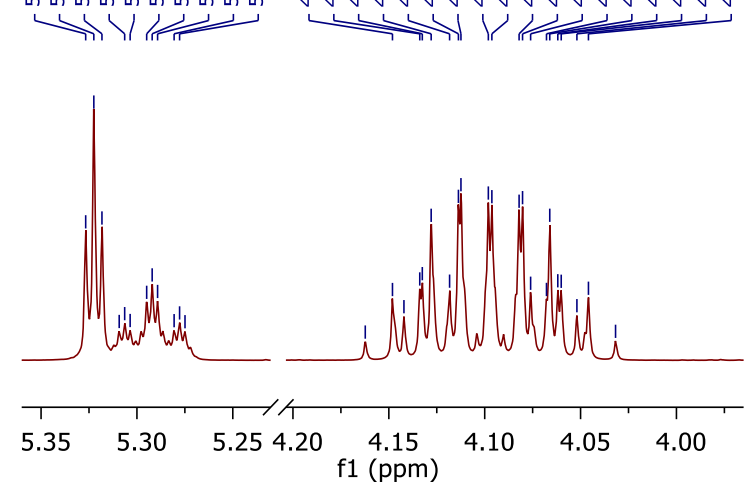

4.15
$\mathrm{f} 1(\mathrm{ppm})$
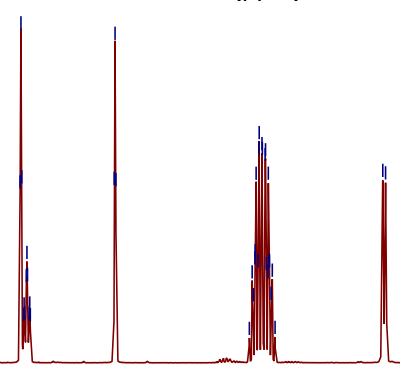

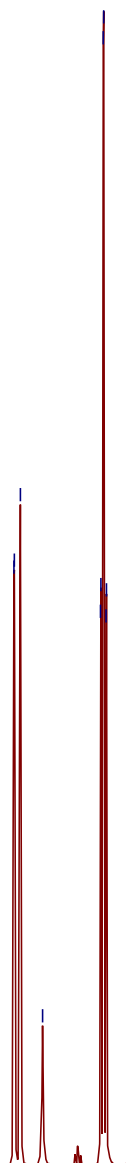

$6.0 \quad 5.5$

政 


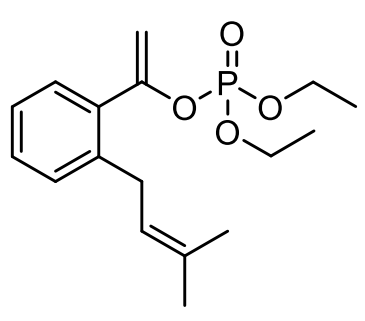

$1 \mathrm{~g}$

${ }^{13} \mathrm{C}\left\{{ }^{1} \mathrm{H}\right\}$ NMR $\left(130 \mathrm{MHz}, \mathrm{CDCl}_{3}, 298 \mathrm{~K}\right)$

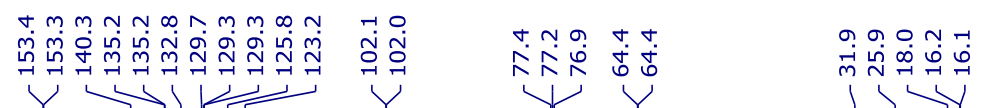

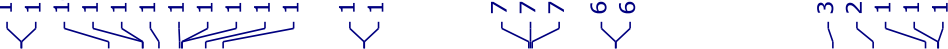

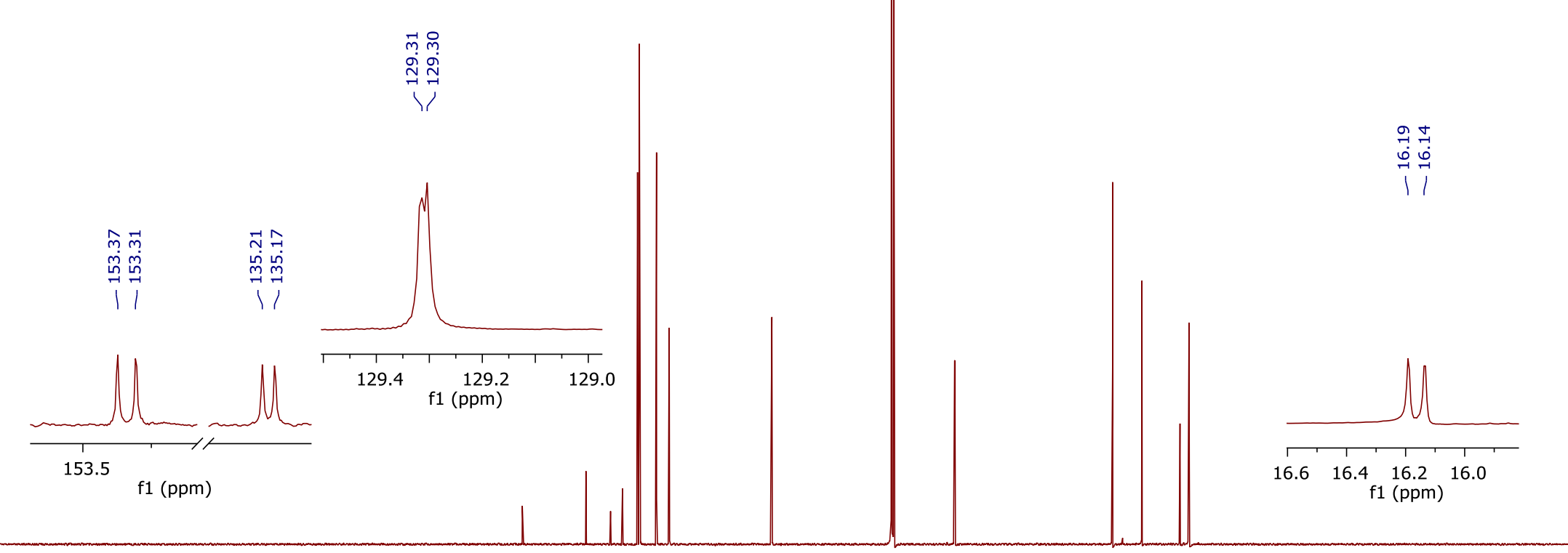

$\begin{array}{lllllllllllllllllllllllllllllllllll}260 & 250 & 240 & 230 & 220 & 210 & 200 & 190 & 180 & 170 & 160 & 150 & 140 & 130 & 120 & 110 & 100 & 90 & 80 & 70 & 60 & 50 & 40 & 30 & 20 & 10 & 0 & -10 & -20 & -30 & -40 & -50 & -61\end{array}$ 1 (ppm) 


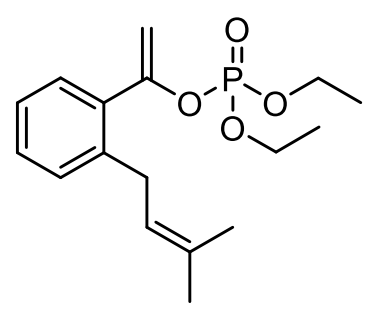

$\underset{\substack{\infty \\ \dot{0}}}{1}$

$1 \mathrm{~g}$

${ }^{31} \mathrm{P}\left\{{ }^{1} \mathrm{H}\right\}$ NMR $\left(160 \mathrm{MHz}, \mathrm{CDCl}_{3}, 298 \mathrm{~K}\right)$

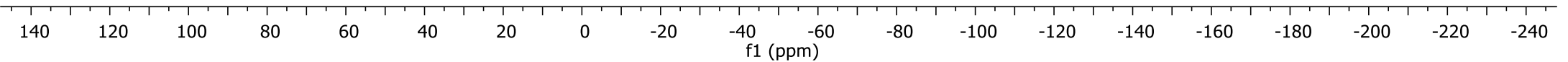




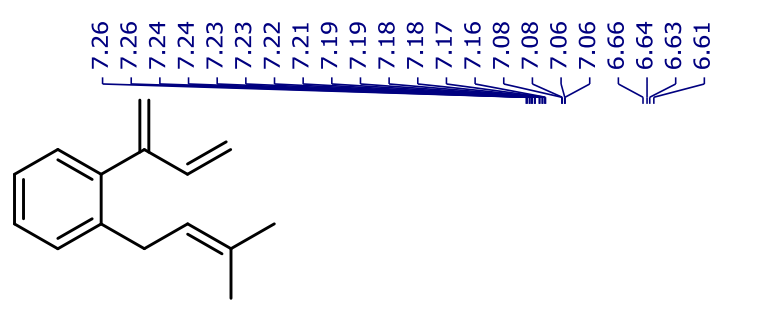

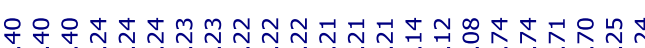

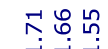

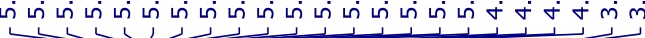

3ag

${ }^{1} \mathrm{H} \mathrm{NMR} \mathrm{(500} \mathrm{MHz,} \mathrm{CDCl}_{3}, 298 \mathrm{~K}$ )

苜

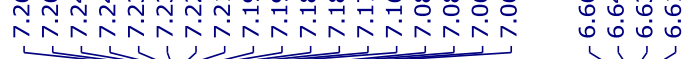

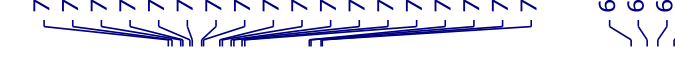
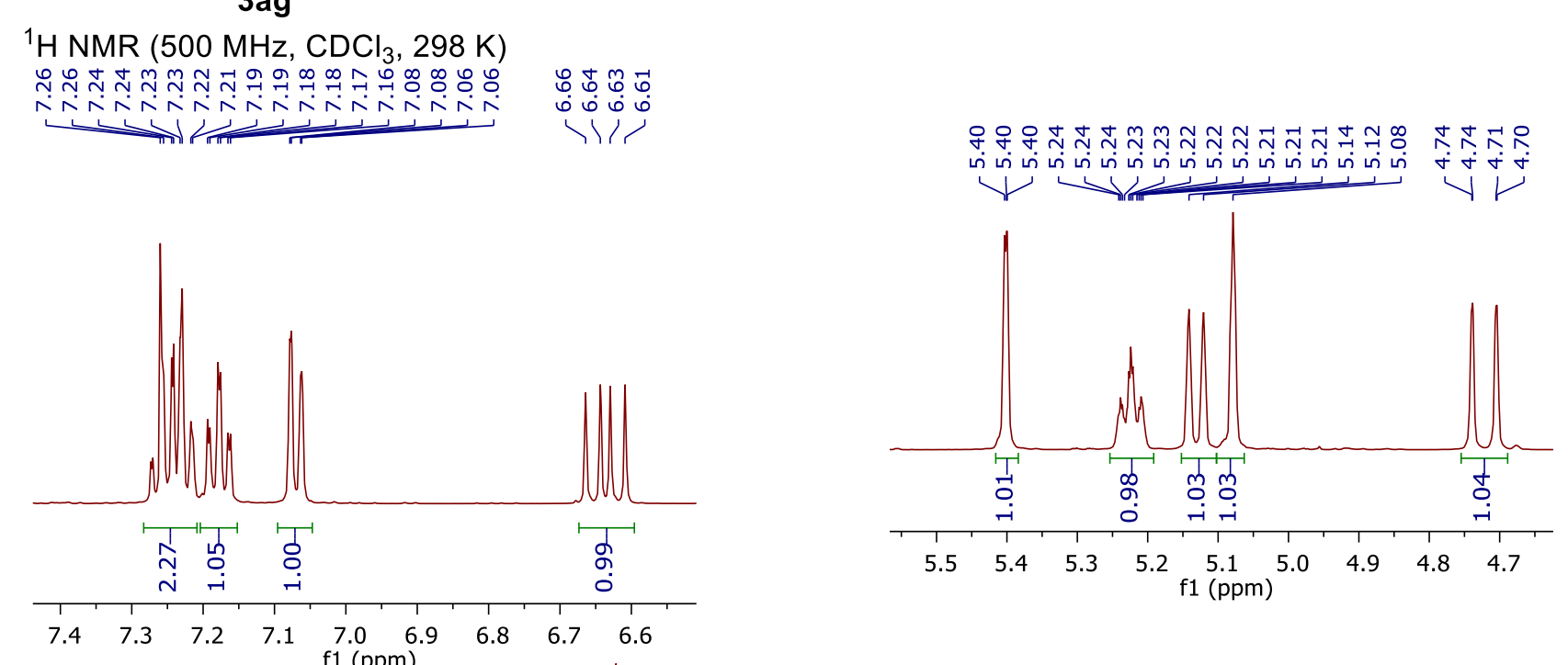

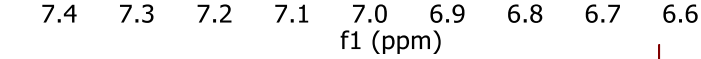
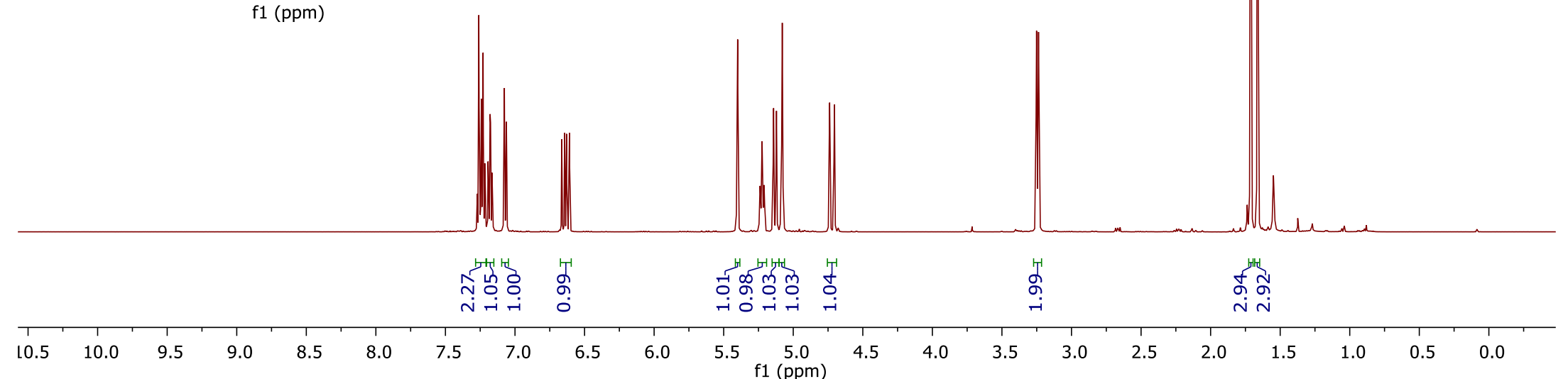

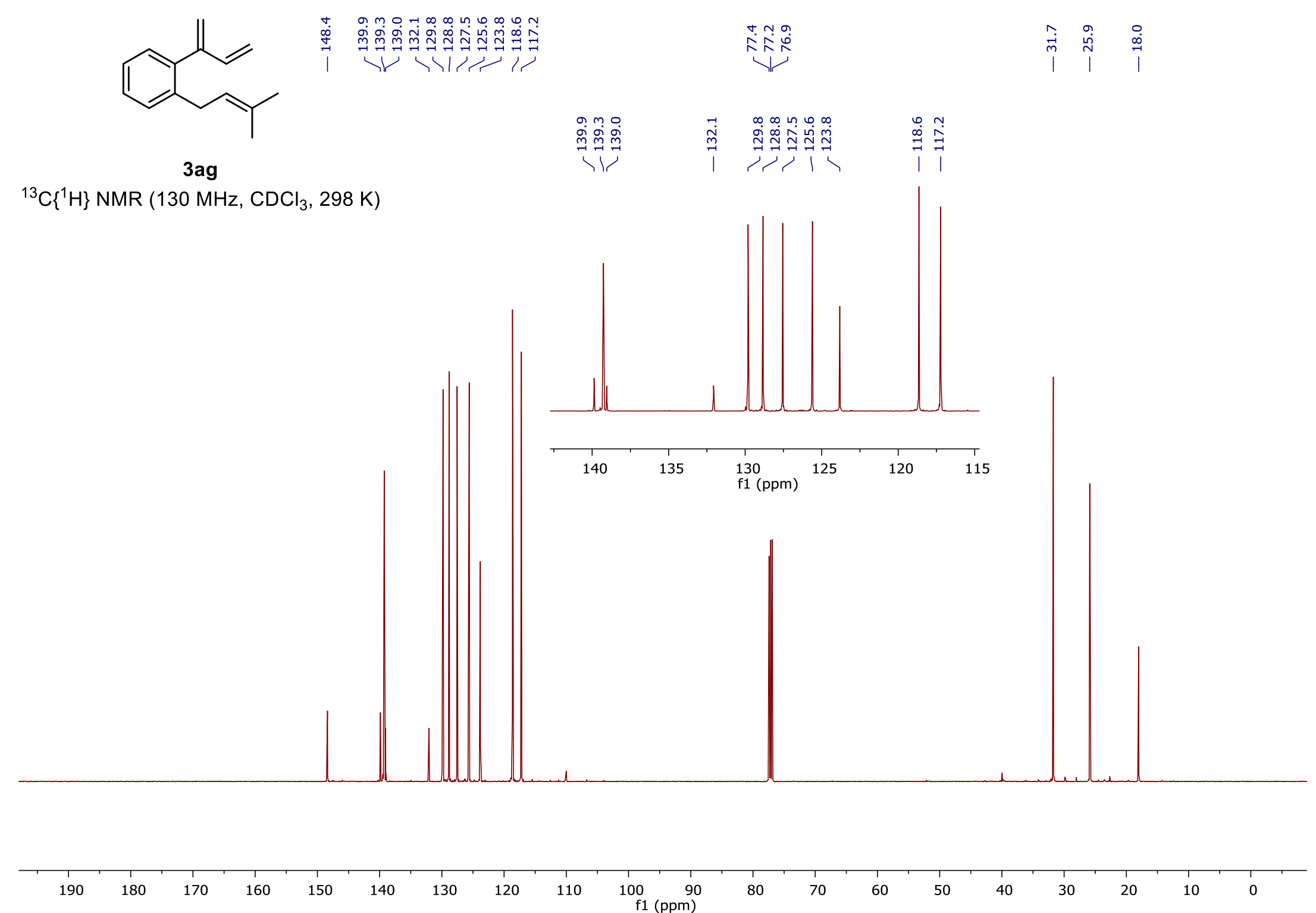